\title{
Evaluation of the impacts of highway construction on sediment and benthic macroinvertebrates in Appalachian streams
}

\author{
Lara B. Hedrick \\ West Virginia University
}

Follow this and additional works at: https://researchrepository.wvu.edu/etd

\author{
Recommended Citation \\ Hedrick, Lara B., "Evaluation of the impacts of highway construction on sediment and benthic \\ macroinvertebrates in Appalachian streams" (2008). Graduate Theses, Dissertations, and Problem \\ Reports. 2706. \\ https://researchrepository.wvu.edu/etd/2706
}

This Dissertation is protected by copyright and/or related rights. It has been brought to you by the The Research Repository @ WVU with permission from the rights-holder(s). You are free to use this Dissertation in any way that is permitted by the copyright and related rights legislation that applies to your use. For other uses you must obtain permission from the rights-holder(s) directly, unless additional rights are indicated by a Creative Commons license in the record and/ or on the work itself. This Dissertation has been accepted for inclusion in WVU Graduate Theses, Dissertations, and Problem Reports collection by an authorized administrator of The Research Repository @ WVU. For more information, please contact researchrepository@mail.wvu.edu. 


\title{
Evaluation of the Impacts of Highway Construction on Sediment and Benthic Macroinvertebrates in Appalachian Streams
}

\author{
Lara B. Hedrick \\ Dissertation submitted to the \\ Davis College of Agriculture, Forestry and Consumer Sciences \\ at West Virginia University \\ in partial fulfillment of the requirements \\ for the degree of \\ Doctor of Philosophy \\ in \\ Forest Resource Sciences \\ Approved by \\ Stuart A. Welsh, Ph.D., Committee Chairperson \\ James T. Anderson, Ph.D. \\ Kyle J. Hartman, Ph.D. \\ Patricia Mazik, Ph.D. \\ J. Todd Petty, Ph.D. \\ Kerry Bledsoe, M.S. \\ Division of Forestry and Natural Resources \\ Morgantown, West Virginia \\ 2008
}

Keywords: benthic macroinvertebrates, construction, cross sectional survey, highway, longitudinal profile, sedimentation, sediment sampler, streams, water quality 


\title{
Abstract \\ Evaluation of the Impacts of Highway Construction on Sediment and Benthic Macroinvertebrates in Appalachian Streams
}

\author{
Lara B. Hedrick
}

\begin{abstract}
Corridor $\mathrm{H}$ is a four-lane highway under construction in north eastern West Virginia. I used a variety of methods to assess the impacts of highway construction in the Lost River watershed, Hardy County, West Virginia. I designed a two part sediment sampler to be used to monitor sediment in paired sites upstream and downstream of highway construction. The twopart design, a base that remains embedded in the substrate, and a removeable trap, allowed for long-term placement of samplers without continual disturbance of the streambed. I used a laboratory flume to compare my sediment sampler design with other devices used to measure stream sedimentation. Based on the flume experiment, the efficacy of our sediment sampler was consistent with that of modified core samplers, and modified Whitlock-Vibert boxes.

I monitored sedimentation using the in-stream sediment sampler at paired sites upstream and downstream of highway construction on two tributaries of the Lost River, Sauerkraut Run and an unnamed tributary. I also monitored changes in the benthic macroinvertebrate communities using an index of biotic integrity, the West Virginia Stream Condition Index. I found little difference in the amount of fine sediment collected at upstream and downstream sites during the three year study. The downstream site on Sauerkraut Run collected significantly greater amounts of sediment in 2003, prior to installation of sediment fencing. Benthic macroinvertebrate metrics did not differ significantly annually or seasonally between sites or between streams.

In addition to monitoring sediment and the benthic macroinvertebrate community on Sauerkraut Run, I also documented changes in the stream channel in response to highway construction and high flow events. Alterations to the streambed during construction included placement and removal of a temporary culvert, straightening and regrading of a section of stream channel, and armorment of a bank with a gravel berm. I surveyed longitudinal profiles and cross sections in a reference reach and the altered reach of Sauerkraut Run from 2003 through 2007 to measure changes in the streambed. Changes to the streambed downstream of construction included channel widening and aggradation and then degradation of the streambed. The reference section remained relatively unchanged.

I assessed the impacts of construction by monitoring benthic macroinvertebrate communities, and water quality, before, during, and after highway construction at paired upstream and downstream sites from 1997 through 2007. Highway construction impacts included an increase in stream sedimentation during the construction phase. This was indicated by an increase in turbidity and total suspended solids. Benthic macroinvertebrate metrics indicate a community more tolerant during, and after construction than in the period before construction. The percent of chironomidae and the Hilsenhoff Biotic Index increased, while percent of Ephemeroptera, Plectoptera, and Trichoptera (EPT) decreased. The variety of methods used in
\end{abstract}


these five chapters allowed better understanding of how various impacts of highway construction, and environmental variables, such as high flows, interact to influence the biota and habitat of streams. 


\section{Dedication}

This dissertation is dedicated to my husband, Jim. He has so graciously given up his time and talents to be my field technician, lab partner, flume design and construction crew, and computer trouble-shooter. Without him, this work would never have come to completion and I am indebted to the time he sacrificed to help me - time when he could have been fishing, or hunting, or working on his own projects. I would also like to dedicate this to my father, Joseph Ras, who had me out on a boat and in the water, fishing and crabbing, and watching the sunrise on the river at a young age. Lastly - to Ryan, Cameron and Tristen - for teaching me the real importance of life. 


\section{Acknowledgments}

The funding for this dissertation research was funded in part by the West Virginia Division of Highways, I am thankful for their support during this long term project. I thank my committee members for all their support and guidance on this project. I thank Pat Mazik for providing me with the knowledge of management and organizing. I have learned much from her leadership skills. I thank Jim Anderson for his countless revisions of manuscripts and his consistent work as a liaison between our department, engineering, and West Virginia Division of Highways. He has kept me consistent in my work and made sure I contacted who I should, when I should, about our work. I thank Kyle Hartman for the use of his equipment, his knowledge and thought and ability to find humor in many situations. To Todd Petty and Kerry Bledsoe - thanks for stepping in at the last minute and serving on my committee.

I am indebted to many many lab technicians and field help - Will Ravenscroft and his crew from Civil and Environmental Engineering accompanied me on most of my field sampling trips. Seth Lemly and Brandon Keplinger identified many of my benthic macroinvertebrate samples. Thanks to David Wellman, Liz Osier, Steve Hammond, Ben Lenz, and Jessica Smith for help with fisheries collections, and to Sandy Taylor, Kaci Orlandi, Dustin Witcherman, and Josh Daniel for the many hours spent picking "bugs" from samples full of leaves and dirt. And thanks to Donna Hartman for keeping all my lab techs in line when I couldn't be around.

I am indebted to Becky Nestor - who has done everything from baby sit to photocopy, to make sure I get a paycheck. I can never repay her for the services she provided and would never have made it to graduation if it wasn't for her knowledge of the system and what to do when. 
My family and friends have supported me, and helped me out as I juggled school and our family. They have watched kids, made meals, and held me accountable when I felt like quitting. They are truly a blessing.

Most of all I'd like to thank Stuart Welsh....for everything you have ever done, from bringing me onto this project to seeing through it's completion. Thank you for all your knowledge and wisdom, for all the statistical help, and your patience as I tried to understand. Thank you for valuing my family, and for giving me the opportunity to continue as a graduate student even though our circumstances did not allow me to be the best graduate student I could be. Thank you for all your emails, field help, and persistence in encouraging me to do the most thorough job I could. I am truly thankful to have had such a wonderful mentor during my graduate experience. 


\section{Table of Contents}

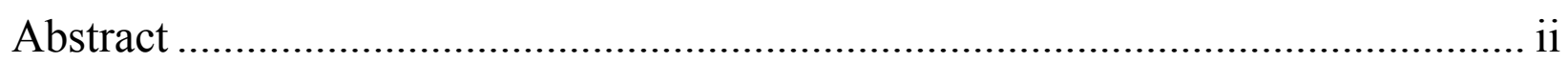

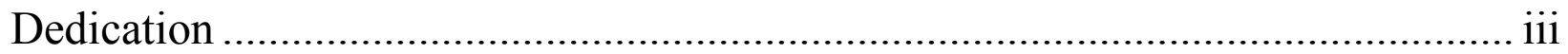

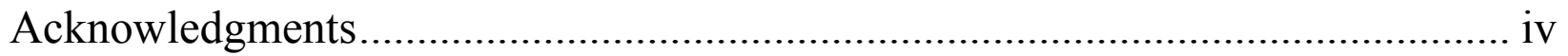

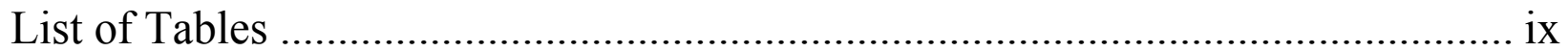

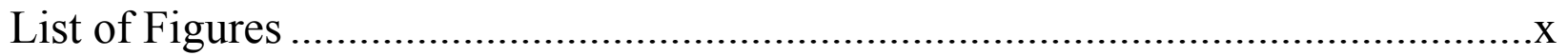

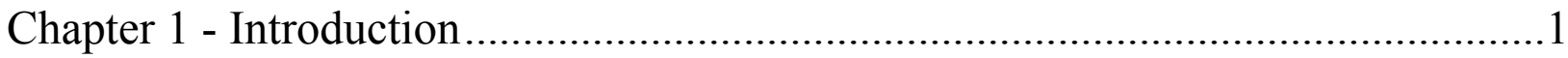

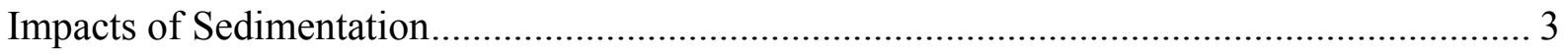

Effects of Sedimentation on Benthic Macroinvertebrates ......................................................... 4

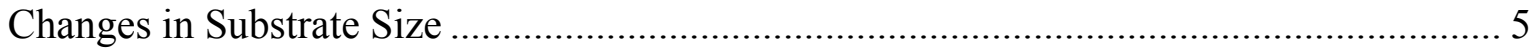

Changes in Community Composition ............................................................................ 6

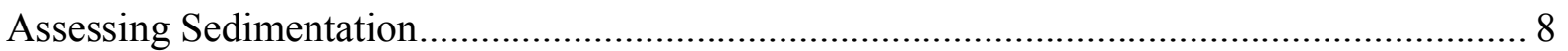

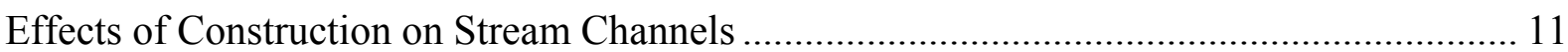

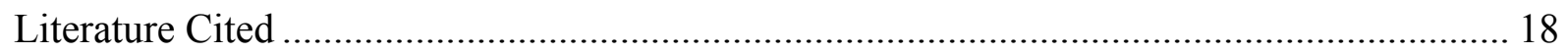

Chapter 2 - A New Sampler Design for Measuring Sedimentation in Streams ......27

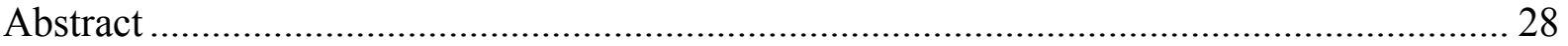

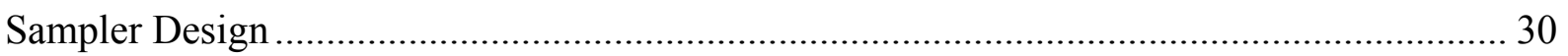

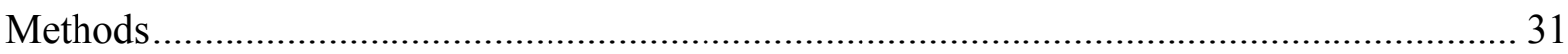

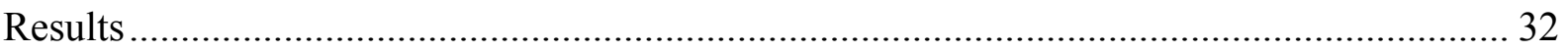

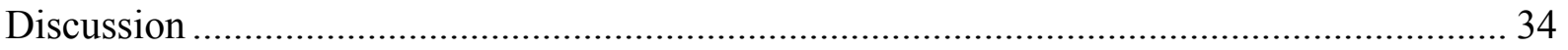

Management Implications ............................................................................................... 37

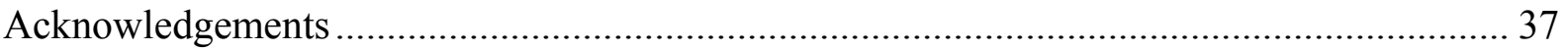

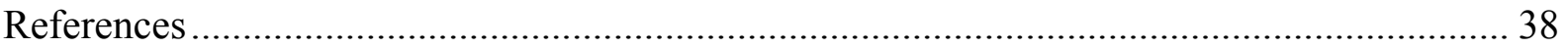




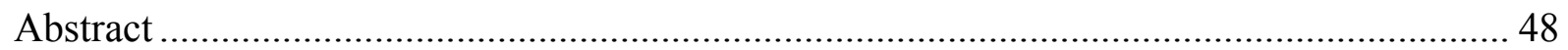

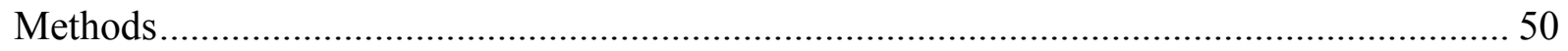

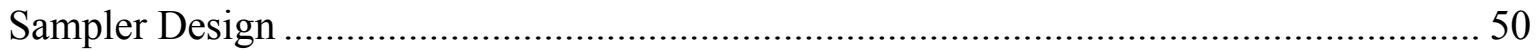

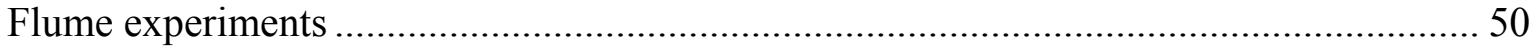

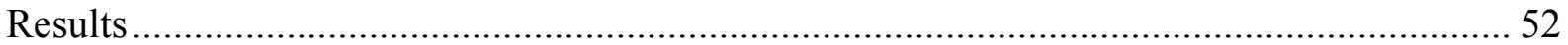

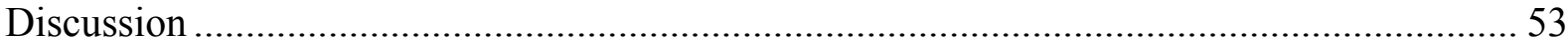

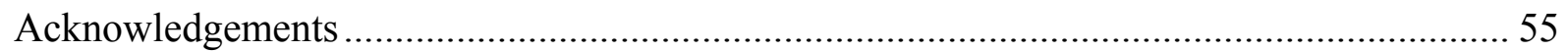

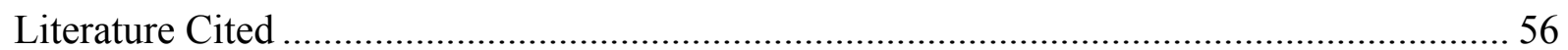

Chapter 4 - Effects of Highway Construction on Sediment and Benthic Macroinvertebrates in Two Tributaries of the Lost River, West Virginia ...............65

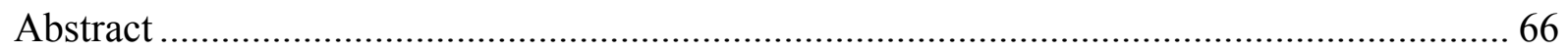

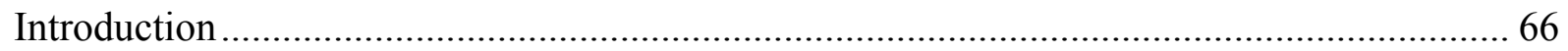

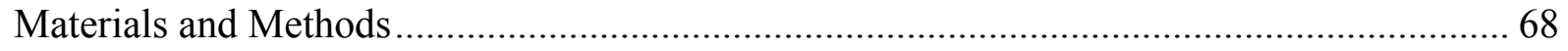

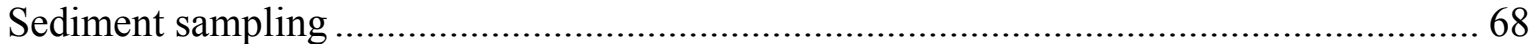

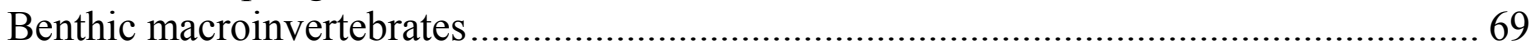

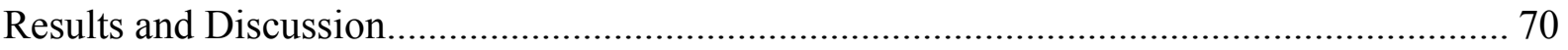

Sauerkraut Run sediment samples.......................................................................... 70

Tributary Stream sediment samples ......................................................................... 72

Benthic Macroinvertebrates ......................................................................................... 73

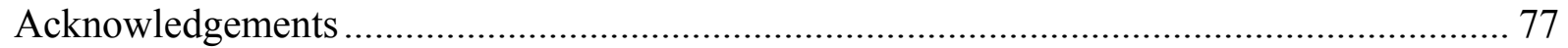

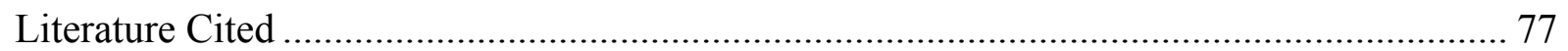

Chapter 5 - Influences of High Flow Events on a Stream Channel Altered by Construction of a Highway Bridge - A Case Study ...............................................86

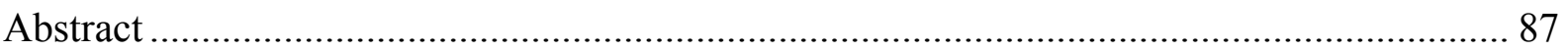

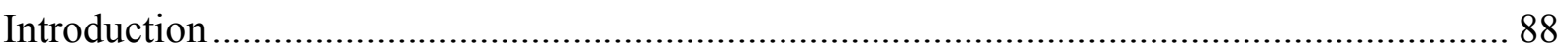

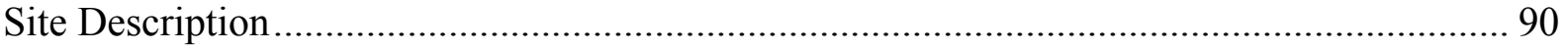

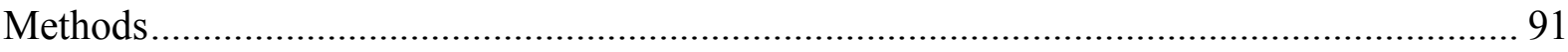




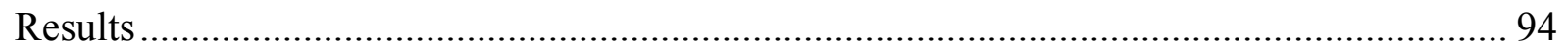

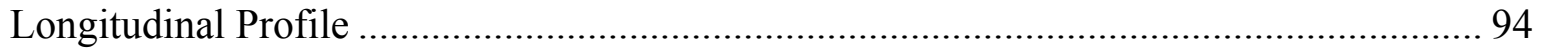

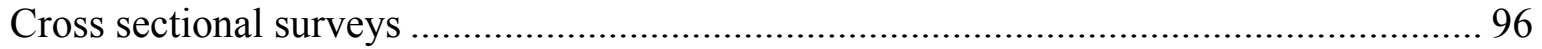

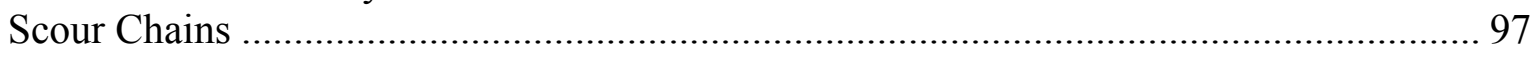

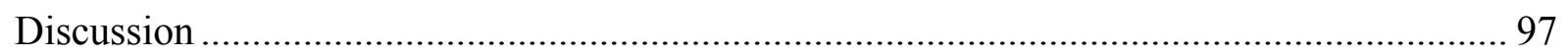

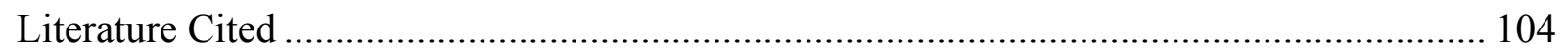

Chapter 6 - Response of benthic macroinvertebrate communities to highway construction in an Appalachian watershed ......................................................... 118

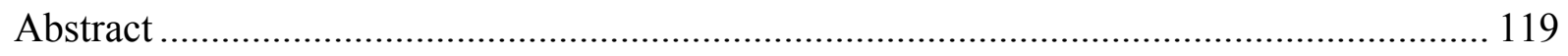

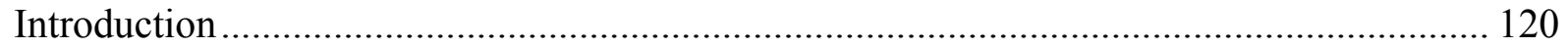

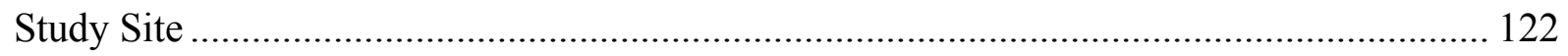

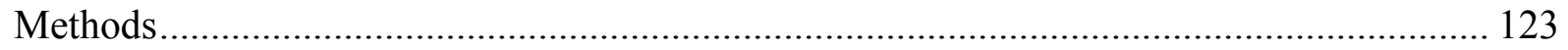

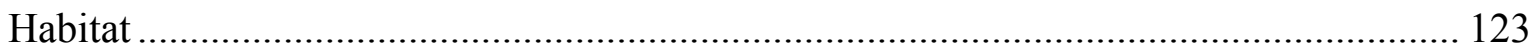

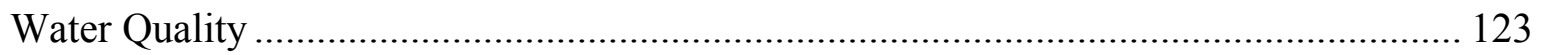

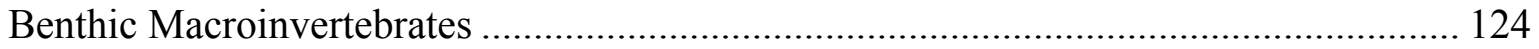

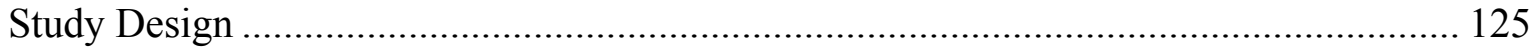

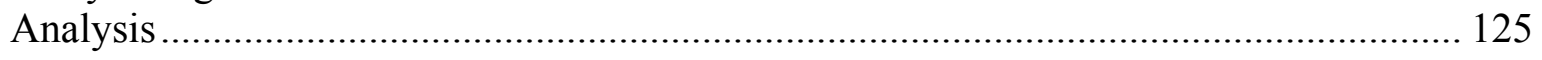

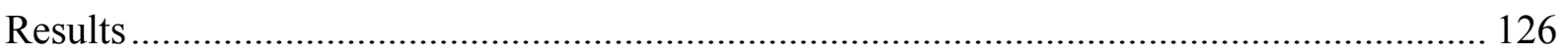

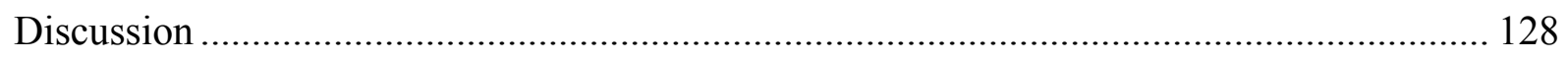

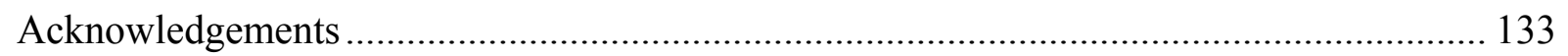

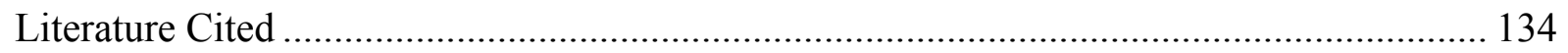

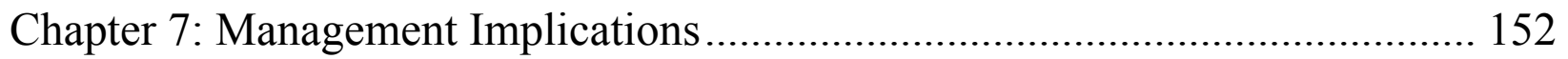

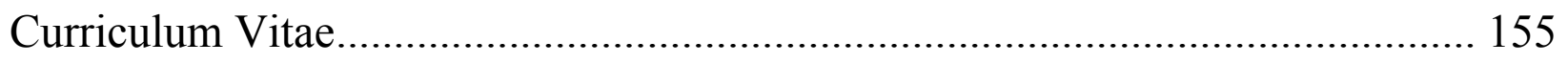




\section{List of Tables}

\section{Chapter 2}

Table 1. Mean water depth $(\mathrm{mm})$ and stream velocity $(\mathrm{m} / \mathrm{s})$ at sampler locations in riffle and pool habitats at the time of sediment trap collections. Values in parentheses are standard deviations.

\section{Chapter 4}

Table 1. Results of the meta-analysis of Sauerkraut Run and Tributary Stream, Lost River, West Virginia. A positive $d$ value indicates that the downstream site collected a higher percentage of sediment. A $*$ indicates significant chi-square values at $p=0.05$.

Table 2. Mean seasonal West Virginia Stream Condition Index (WV-SCI) for benthic macroinvertebrates at upstream and downstream sites in Sauerkraut Run and Tributary Stream, Lost River, West Virginia.

Table 3. Regression coefficients associated with linear regression analysis of benthic macroinvertebrate WV-SCI scores and sediment data from Sauerkraut Run and Tributary Stream, Lost River, West Virginia. 83

\section{Chapter 5}

Table 1. Stream cross sectional measurements associated with the Reference Reach and Altered Reach on Sauerkraut Run, Hardy County, West Virginia. $\Delta \mathrm{A}$ is the measured change in area, $\Delta \mathrm{A} \%$ is the change in percent of stream cross sectional area, $|\Delta \mathrm{A} \%|$ is the absolute value of the percent change in stream cross sectional area. Values with different letters within a column are significantly different $(\mathrm{p}<0.05)$.

\section{Chapter 6}

Table 1. Water quality variables associated with upstream and downstream sites in the Lost River watershed, West Virginia. Ranges of each variable are reported from the monitoring period of 1998 through 2007.

Table 2. Results from ANCOVA of metrics associated with the benthic macroinvertebrate at sites located downstream of highway construction in the Lost River watershed, Hardy County, West Virginia. 


\section{List of Figures}

\section{Chapter 2}

Figure 1. Original and amended sediment sampler designs and steps in deploying and retrieving the sampler.

Figure 2. Mean dry weight (g) and standard error bars of sediment accumulated in each size class during the three six-week periods at sites upstream and downstream from highway construction. Mean values with different letters are significantly different $(P<0.05)$.

Figure 3. Mean dry weight (g) and standard error bars of sediment accumulated per size class (class 1: greater than $4.70 \mathrm{~mm}$; class 2: 2.28 to $4.70 \mathrm{~mm}$; class 3: 1.40 to $2.28 \mathrm{~mm}$; class 4: 0.98 to $1.40 \mathrm{~mm}$; and class 5: less than $0.98 \mathrm{~mm}$ ) in a six-week period in sediment samplers and adjacent Whitlock -Vibert boxes. Mean values with different letters within class are significantly different $(P<0.05)$. There are no among class comparisons.....

\section{Chapter 3}

Figure 1. Original sediment sampler design consisting of a stationary base and removable trap (for details on manufacturing see Hedrick et al. 2005).

Figure 2. Wooden flume designed for sediment sampler experiments. Water source is located below the panel. Sediment was added to the panel and water was allowed to wash the sediment into the flume.

Figure 3. Mean amount of (A) sand accumulated in sediment samplers $(n=18)$ and removed with core samples $(n=12)$ and $(B)$ sand accumulated in sediment samplers $(n=12)$ and $W-V$ boxes $(n=12)$ from three trials in an experimental flume. Error bars indicate $95 \%$ confidence intervals.

Figure 4. Mean amount of sand accumulated in (A) sediment samplers $(n=9)$ per row and surrounding core samples $(n=12)$ and $(B)$ sediment samplers $(n=6)$ and $W-V$ boxes $(n=6)$ per row from three combined trials in an experimental flume. Error bars indicate $95 \%$ confidence intervals.

\section{Chapter 4}

Figure 1. The percent of fine sediment and total amount of sediment collected at upstream and downstream sites on Sauerkraut Run and Tributary Stream. Vertical bars indicate plus and minus one standard error; a $*$ indicates significant difference between sites $(p<0.05)$. 


\section{Chapter 5}

Figure 1. Location of the Lost River watershed and Sauerkraut Run, a first order tributary of

the Lost River, Hardy County, West Virginia, USA.

Figure 2. Longitudinal profile of Sauerkraut Run showing (A) the thalweg on the entire reach surveyed; (B) the thalweg of the reference reach; and (C) the thalweg of the altered reach from 2004 through 2007.

Figure 3. Stream cross sectional profiles of the reference reach before and after high flow events on Sauerkraut Run, Hardy County, West Virginia. $\Delta \mathrm{A} \%$ is the change in percent of stream cross sectional area, $|\Delta \mathrm{A} \%|$ is the absolute value of the percent change in stream cross sectional area, $\mathrm{w} / \mathrm{d}_{\text {pre }}$ is the width to depth ratio before high flow, w/d diff is the difference in the width to depth ratio before and after high flow, $\mathrm{G}_{\text {pre }}, \mathrm{G}_{\text {post }}$, and $\mathrm{G}_{\text {diff }}$ relate to the Gini coefficient.

Figure 4. Stream cross sectional profiles of the altered reach before and after high flow events on Sauerkraut Run, Hardy County, West Virginia. Notation is defined in Figure 3...... 115

Figure 5. Photos of Altered Reach 2 on Sauerkraut Run indicating changes in stream bed. The white dot indicates the same tree in each photo. Photo 7-5-02 showing large alluvial material; photo 4-5-03 showing removal of that material following high flow; photo 10-1203 showing deposition of gravel bed; photo 12-21-03 showing removal of gravel bed following high flow.

Figure 6. Photos of the temporary culvert placed in Sauerkraut Run in April 2002 and removed in September 2004. Arrows indicate location of culvert, black dot indicates the same rock in the photos. Photo 7-5-02 showing area upstream of culvert prior to vegetation removal; photo 10-18-03 showing area upstream of culvert after vegetation has been removed; photo 6-18-04 showing plunge pool downstream of culvert; photo 9-26-04 showing regarded section of stream following removal of culvert with plunge pool removed. 117

\section{Chapter 6}

Figure 1. Location of study sites in the Lost River watershed, Hardy County, West Virginia, USA.

Figure 2. Time series of water quality variables associated with sites upstream and downstream of highway construction. Means with standard error bars are plotted by season ( $\mathrm{F}=$ fall, $\mathrm{SP}=$ spring, and year); vertical bars indicate plus and minus one standard error. Highway construction occurred within the time period of Fall 2000 through Fall 2003 (bracketed by vertical bars).

Figure 3. Mean values of metric scores with standard error bars associated for sites upstream and downstream of highway construction during three construction time periods, 
before, during, and after construction. Mean values with different letters differ significantly

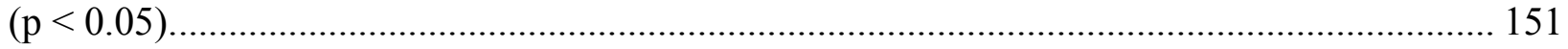




\section{Chapter 1 - Introduction}

Corridor H, a four-lane highway under construction in north eastern West Virginia, will cross both the Appalachian Plateaus (Allegheny Mountain section), and Ridge and Valley physiographic provinces, including Randolph, Tucker, Grant, and Hardy counties. In 1965, Congress passed the Appalachian Regional Development Act which created the Appalachian Regional Commission (ARC), and authorized the Appalachian Development Highway System (ADHS). This system covers the Appalachian region from New York to Mississippi. In 1965 ARC designated Appalachian Corridor $\mathrm{H}$ as one of 23 transportation corridors of the ADHS (West Virginia Department of Transportation 2002). During the 1970s, studies began on the proposed Corridor $\mathrm{H}$ from Elkins to Interstate 81, and a Draft Environmental Impact Statement was initiated in the early 1980s. A lack of funding stalled the project in 1984 . The Corridor H project was resurrected in 1990. Between 1992 and 1994 the Federal Highway Administration (FHWA) completed a Corridor Selection Draft Environmental Impact Statement. In 1996, FHWA completed an Alignment Selection Draft Environmental Impact Statement, and initiated a supplemental Environmental Impact Statement (EIS). In 1996 and 1998, the Corridor H Alternatives group issued two lawsuits, which were not settled until December of 1999. In May 2000, construction began on the Moorefield to Baker section of the project (West Virginia Department of Transportation 2002).

A supplemental EIS, in 1996, covered the segment from Elkins, WV to the West Virginia-Virginia state line, and included a provision for the West Virginia Division of Highways (WV DOH) to study a minimum of ten streams along the preferred alignment of the highway. The study was to determine if the construction and operation of Corridor $\mathrm{H}$ negatively impacts stream ecology, and was initiated in 1997 by Salem International University, Salem, 
West Virginia. In January 2000, the study moved to West Virginia University with collaboration among the Department of Civil and Environmental Engineering, the West Virginia Cooperative Fish and Wildlife Research Unit, and the Wildlife and Fisheries Resources program.

This dissertation research evaluated the environmental impacts associated with construction of a four-lane highway through the Lost River watershed, Hardy County, West Virginia. Although many researchers have studied the effects of road construction on aquatic communities (King and Ball 1965; Barton 1977; Beschta 1978; Chrisholm and Downs 1978; Cline et al. 1982; Eaglin and Hubert 1993; King et al. 2000; Wellman et al. 2000), few examined impacts of highway construction on streams in mountain areas (Chrisholm and Downs 1978; Cline et al. 1982). Many studies have assessed effects of sedimentation or siltation (Barton 1977; Beschta 1978; Cline et al. 1982; Eaglin and Hubert 1993; King et al. 2000; Wellman et al. 2000), but a review by Henley et al. (2000) found inconsistent patterns of environmental impacts among studies. Some important impacts to stream environments from highway construction include an increase in inorganic sediments (King and Ball 1965) due to erosion of exposed, unvegetated channel banks (Urban and Rhoades 2003), an increase in erosion of the disturbed land surface due to recontouring and leveling (Wohl 2000, Wohl 2006), and alteration of the natural stream channel by channel realignment, placement of culverts and construction of bridges (Duck 1985, Johnson 2002, Johnson 2006). The following literature review includes sections on the impacts of sedimentation, the effects of sedimentation on benthic macroinvertebrates, assessing sedimentation, and effects of construction on stream channels. 


\section{Impacts of Sedimentation}

Over the past few decades, many studies have summarized sedimentation as the single greatest water pollutant affecting streams throughout the United States (Judy et al. 1984, USEPA 1990, Richter et al. 1997). In the 1982 National Fisheries Survey, Judy et al. (1984) reported that respondents (fisheries managers with greater than 9 years experience in states throughout the U.S.) ranked siltation as the major concern in all streams, and excessive sedimentation ranked number one in sources adversely affecting fishery habitats. Based on the USEPA 1988 inventory of stream and water quality, siltation affected $42 \%$ of impaired stream miles in the United States (USEPA 1990). In 1992, siltation affected $45 \%$ of the impaired stream miles (USEPA 1994). Sedimentation in streams can be defined in two ways, the concentration of suspended sediment, or turbidity; and deposited sediment, or sedimentation on the streambed (Wood and Armitage 1997). A forested watershed provides the baseline condition for measurement of the natural inputs of sediment in a stream channel. This type of landscape provides the least amount of impervious surface, and the greatest amount of root protection (Schueler 2000). Any other land use has the potential to create extra sediment inputs. Land uses that have the greatest potential to impact stream sediment include agriculture, forestry, mining, and urban development (Waters 1995, Wood and Armitage 1997).

The main sources of sedimentation during urban development are from construction and excavation associated with development of roads, bridges, and housing communities (Angermeier et al. 2004). Parking lots and other impervious surfaces increase the amount of runoff a stream receives after a storm event. Increased velocities in streams with accelerated run off causes an increase in erosive forces, undercut banks, and heavy sediment loads (Albanese and Matlack 1998). Highway construction creates a large amount of bare earth especially in 
mountainous areas. Large increases of sediment in streams affected by highway construction most commonly occur after periods of heavy rains (King and Ball 1965). Often sediment ponds or fencing are not adequate for such events. However, unlike agriculture, which is a permanent land use, construction projects are often short term, and site remediation can return sediment deposition and suspended solid levels back to pre-construction conditions (Barton 1977). In comparing urban streams to those in agriculture areas, Schueler (2000) found that urban streams had less sedimentation than streams impacted by agriculture. The main source of sediment was from stream bank erosion, resulting from channelization of streams.

\section{Effects of Sedimentation on Benthic Macroinvertebrates}

The effects of sedimentation on benthic macroinvertebrates and fishes in streams are widely diverse. Excessive stream sedimentation, resulting from anthropogenic land disturbances, can alter community composition and abundance of aquatic biota (Rabeni and Smale 1995, Jones et al. 1999), decrease reproductive success and survival of fishes (Scrivener and Brownlee 1989, O’Conner and Andrew 1998), decreases survival of benthic macroinvertebrates due to deposition of silt on the gills (Lemly 1982) and impact feeding performance of fishes (Sweka and Hartman 2001).

Benthic macroinvertebrates, inhabitants of the stream bottom, are sensitive to changes in the streambed resulting from deposited sediments. Many fishes eat benthic invertebrates, hence, influences of sediment deposition on benthic organisms are an important problem for stream fisheries (Waters 1995). 


\section{Changes in Substrate Size}

Benthic macoinvertebrate abundance is positively correlated with particle size of stream substrate. Abundances generally increase across the particle size gradient of sand-gravel-pebblecobble. A relationship also occurs between invertebrate diversity and abundance and substrate heterogeneity. Abundances are least in homogeneous sand or silt, or in large boulders and bedrock. A mixture of gravel, pebbles, and cobble generally support higher abundances and high species diversity for intolerant taxa of benthic macroinvertebrates (Minshall 1984). The principal taxa available for many fish invertivores come from the orders Ephemeroptera, Plecoptera and Trichoptera (EPT). These taxa are sensitive to sediment pollution and typically decrease in abundance in homogenous substrate habitat. Burrowing organisms, such as chironomid larvae and oligochaetes are more common in silt and mud (Cummins and Merritt 1996).

Brusven and Prather (1974) examined the effects of substrate on the distribution and abundance of stream insects in two streams in northern Idaho. Ephemeroptera occurred in both streams, but were limited in distribution to areas with lightly sanded riffles. Numbers of species and individuals decreased in heavily silted areas. Stoneflies were uncommon and not detected in sandy-silted habitats. Trichoptera species were only found in faster, unsilted riffles. In a laboratory study, stonefly nymphs selected interstitial spaces between gravel and cobble (Brusven and Prather 1974). As interstitial spaces decreased due to sedimentation, nymphs shifted habitat to the underside of cobble. Mayfly species shifted habitat to larger sediments and unembedded cobble for the same reasons.

Cline et al. (1982) evaluated the response of a high elevation Rocky Mountain stream to highway construction over a three-year period. Suspended solids and sediment increased at the 
impacted study sites during construction. However, values at impacted sites approached reference site levels within two weeks after construction ended. Densities of benthic macroinvertebrates at impacted sites were lower than those from reference sites during and immediately following construction. Within one year after construction, values were comparable to reference sites. The taxa most intolerant to construction effects were from the orders Ephemeroptera, Plecoptera, and Trichoptera (Cline et al. 1982).

In a study relating riparian grazing, sediment loads, and benthic macroinvertebrates, Wohl and Carline (1996) documented the highest densities of benthic organisms in areas with low sediment loads. Densities declined with increasing sediment load and decreasing substrate size. In their study, densities of ephemeropterans and tricopterans (two taxa typically sensitive to changes in water quality), did not demonstrate a trend in relation to sediment (Wohl and Carline 1996).

\section{Changes in Community Composition}

Lamberti and Berg (1995) examined the effects of increased sedimentation on densities of benthic macroinvertebrate taxa of different functional feeding groups in a northern Indiana stream. Densities of four of six filter feeding taxa were reduced by $95 \%$ in response to increased sedimentation. Densities increased for five of six collector-gatherers. Negative effects to collector-filterers included a decreased availability of stable substrates on which to attach, and interference with feeding mechanisms. The effects of sedimentation on shredders varied depending on microhabitat preferences. Taxa that preferred stream margins benefited from the increased deposition of detritus. However, taxa that preferred coarse substrate were negatively affected (Lamberti and Berg 1995). 
Smith and Kaster (1983) conducted a study on benthic macroinvertebrate abundance and composition at four sites along a southeastern Wisconsin stream crossed by a four lane rural highway. The site that received the least amount of highway runoff was the most dissimilar to the control site with decreased densities, biomass, and pollution-sensitive fauna. This site had a lower current velocity and increased silt in the surface of the substrate. The sites that received the most highway runoff were similar to the control, and the site receiving the most runoff had higher densities, biomass, and pollution-sensitive taxa than the control site.

Burns (1972) studied the effects of logging and associated road construction on four California trout streams. Sediment and turbidity increased substantially and decreases were found in most taxa of aquatic invertebrates. However, logging operations were short term and densities of benthic organisms increased by $100 \%$ in two years. Ephemeroptera took longer to recover than other insect orders.

In an environmental impact study of highway construction across Halon Creek, a small stream in Ontario, Barton (1977) found no differences in the number of benthic macroinvertebrates, but species composition changed with an increase in tolerant taxa and a decrease in sensitive taxa. At one monitoring site the streambed was completely removed during culvert construction. The riffles were replaced after culvert completion and species composition and abundance recovered to pre-construction levels within a year (Barton 1977).

Kaller and Hartman (2004) evaluated the response of benthic macroinvertebrate community composition to varying amounts of sedimentation in seven Appalachian streams. The EPT taxa richness decreased in streams with fine substrate particles $(<0.25 \mathrm{~mm})$ exceeding $0.8-0.9 \%$ of riffle substrate composition. However, no significant differences were found in benthic macroinvertebrate density or biomass (Kaller and Hartman 2004). 
Chrisholm and Downs (1978) monitored benthic macroinvertebrates at four sites on Turtle Creek, a stream impacted by the construction of Appalachian Corridor G. Diversity and abundance decreased during the construction of the highway. Repopulation and diversification occurred quickly within disturbed and newly created reaches of Turtle Creek. Within about one year, the benthic macroinvertebrate population of the disturbed stream was similar to that of the control stream. The successful recolonization was attributed, in part, to tributary inflow and benthic macroinvertebrate drift from unaltered reaches and best management practices such as bank recontouring and reseeding (Chrisholm and Downs 1978).

\section{Assessing Sedimentation}

Quantitative measures of stream sedimentation are useful to monitor and study anthropogenic impacts on stream biota, and stream sedimentation is measurable with multiple sampling methods. Evaluation of sedimentation can be made by measuring the concentration of suspended sediment, or turbidity, and by determining the amount of deposited sediment, or sedimentation on the streambed (US EPA 1996). Turbidity is a measure of the collective optical properties of a water sample that cause light to be scattered and absorbed (Bescheta 1996, US EPA 1997). Suspended sediment is usually the major contributor to turbidity, however other materials are also contributors, such as plankton and organic detritus. Turbidity is typically measured in nephelometric turbidity units (NTU), and is done in the field using a nephelometer. Suspended sediments are measured in parts per million (ppm; $\mathrm{mg} / \mathrm{L}$ ), from grab samples filtered, dried, and weighed in the laboratory (Beschta 1996, US EPA 1997).

Measurements of deposited sediments are more time consuming and labor intensive than measurements of suspended sediments. Traditional techniques for characterizing sediment 
composition in streams include core sampling (McNeil and Ahnell 1964; Platts et al. 1989; Wellman et al. 2000), the shovel method (Grost et al. 1991, Hames et al. 1996), and visual estimation along transects (Platts et al. 1989; Eaglin and Hubert 1993). The original McNeil Ahnell core sampler technique was published in 1964. Prior to the creation of this sampling device, “core sampling” was done using open cylinders (McNeil and Anhell 1964). The technique involved sinking a stainless steel round sampler about $15.3 \mathrm{~cm}$ into the substrate. The contents of the tube were then removed by hand. Fines were removed with a settling funnel, and the substrate material was wet sieved into various size classes. The McNeil Anhell sampler has been modified by various researchers to meet specific needs (Platts et al. 1989, Wesche et al. 1989). Other techniques to evaluate the substrate material have also evolved, including drying before sieving. Core sampling is effective, but can be labor and equipment intensive, and it is difficult to insert the sampler to a specified depth in coarse or compacted substrate (Platts et al. 1989).

The shovel method produces lighter samples, which are less costly, and can be taken more quickly than the McNeil sampler (Grost et al. 1991, Hames et al. 1996). Grost et al. (1991) compared five paired sediment samples collected from each of five sites using a McNeil sampler, a shovel, and a single-probe freeze-core. They found no significant difference in sediment composition between the McNeil sampler and shovel. Hames et al. (1996) compared the composition of spawning gravel samples collected using three shovel-based methods to samples collected by the McNeil sampler. The three shovel based methods included a standard number 2 round-point shovel (S1); a standard number 2 round-point shovel with a portable stilling well (S2); and a modified shovel with side walls. At least 24 paired samples for each McNeil/shovel combination was collected from two different study sites in southern Puget Sound. The 
percentage of fines did not differ significantly between the McNeil sampler and S2 samples in Kennedy Creek; the McNeil sampler had a greater percentage of fines than the S1 and S3 methods. For Snookum Creek samples, the percentage of fines did not differ significantly between any of the shovel-based methods and the McNeil sampler. Sediment is washed off of the shovels during transport through the water column, and this loss of sediment represents a sampling bias that increases with water depth and velocity (Hames et al. 1996).

Both the core sampler and shovel method disturb a portion of the streambed during each use (Berkman and Rabeni 1987, Platts et al. 1989). These methods, used usually for single or annual measurements of sediment, are not effective for repeated sampling over long time intervals (e.g., monthly sampling) due to labor intensiveness and cost. To reduce labor and cost, several techniques for trapping sediment were developed. Wesche et al. (1989) devised a sediment trapping method using Whitlock-Vibert (W-V) boxes. These polypropylene mesh boxes are typically used to incubate fish eggs in stream gravels. The authors modified the boxes by filling them with clean gravel and adding a strip of duct tape to prevent the loss of trapped sediment through the bottom. The W-V boxes were buried in the substrate. Experiments were conducted in a laboratory flume and field testing were done on the North Fork of Little Snake River, Wyoming. The sediment from W-V boxes was compared to core samples taken in the same stream reach. Whitlock-Vibert boxes were as effective at measuring fine sediment as the core samples (Wesche et al. 1989). The ability to transport the traps easily to remote locations, small sample volumes, and decreased analysis times were cited as benefits to the Wesche method over core sampling.

Lachance and Dube (2004) created another trapping device using two cylindrical containers with perforated walls. Two cylinders (one inside the other) are placed into the 
streambed with openings aligned. At retrieval, rotation of the inner container closes the device and prevents loss of fine material. This sampler is cost effective, and avoids the problem of sediment loss in W-V boxes (Lanchance and Dube 2004).

\section{Effects of Construction on Stream Channels}

Natural channels are achieved by allowing a stream to develop a stable dimension, pattern and profile. In a stable system, the streambed neither aggrades nor degrades, and its sediment load is consistently transported (Schumm 1977, Allen 1995). Channel instability occurs when a streambed is degraded by scouring processes, or excessive sediment deposition leads to aggradation (Rosgen 1996). Wolman (1967) initially categorized stages of stream channel change in response to urbanization. The first stage is equilibrium and stream channel stability. As development and construction begin in the second stage, sediment delivery rates increase leading to channel aggradation. The third stage is an urban landscape with increased areas of impervious surfaces leading to decreased sediment inputs and channel degradation due to flashy discharge and low sediment yield (Wolman 1967). Subsequent studies on effects of urbanization indicate that stream channels respond to early stages of construction by an increase in sediment influx resulting from erosion of exposed, unvegetated channel banks (Urbana and Rhoades 2003) and the land surface due to recontouring and leveling (Wohl 2000, Wohl 2006). Enlargement of the floodplain can occur as excessive sediment material is deposited as floodplain alluvium (Graf 1975). Response to increased urbanization includes channel widening (Hammer 1972, Grabel and Harden 2006, Colosimo and Wilcock 2007), channel incision (Booth 1990, Doyle et al. 2000), erosion of unarmored banks, and aggradation of the stream bed (Hess and Johnson 2001, Grabel and Harden 2006, Colosimo and Wilcock 2007). 
Road crossings such as bridges and culverts can influence stream hydraulics and sediment transport (Duck 1985, Johnson 2002, Johnson 2006). Bridges can either be single span, with no pillars in the stream, or multiple span, with one or more pillars in the stream. Pillars in the stream alter the natural flow regime and cause scouring upstream, and deposition downstream. Bridges and culverts often restrict flow across the floodplain due to high embankments or approaches to the bridge or culvert. A stream channel that was straightened and constricted with steep banks may not allow flow to cross into the floodplain. The importance of the floodplain is to dissipate the energy of flows exceeding the effective discharge (Ward et al. 2002). If a culvert is present, the water can back up upstream creating localized channel widening. If the flow is forced to remain in the channel instead of intercepting the floodplain, it will increase the sheer stress and velocity, resulting in bank erosion and bank failure, and streambed degradation (Graf 1975, Richardson and Davis 2001, Johnson 2002).

Roads that cross a stream at mid slope and bridge spans built on cut and fill material can be sources for debris flows (Jones et al. 2000). Debris flows are rapid movements of soil, sediment, and organic matter down steep stream channels. Heavy rain events can trigger landslides of the fill material, and if near a stream, can result in a debris flow within a stream channel. Debris flows can move downstream, encounter a road or culvert, and either continue movement of fill downstream or deposit it. The major impact of debris flows is movement and rearrangement of sediment. Debris flows mainly occur during floods and are most severe on small, steep stream segments (Jones et al. 2000). If the stream can not carry the sediment load, it may be deposited on the floodplain, creating new areas, and enlarging existing areas by vertical accretion (Graf 1975). 
Road construction along stream corridors alters the structure, function, and stability of stream channels (King and Ball 1965, Albanese and Matlack 1998). The stability of a stream is associated with a balance between variables such as width, depth, velocity, slope, sediment volumes and sediment sizes. Changes in a stream's dimension, pattern, and profile due to changes in these variables can result in deteriorated water quality (US EPA 1994, Trimble 1997), reduction in quality and diversity of habitat and negative impacts on the aquatic communities (Rabeni and Smale 1995; Jones et al. 1999), and land loss through erosion (Hammer 1972, Rosgen 1996).

Monitoring a stream over time can provide information on the response of a stream to alteration, such as aggradation, degradation, or lateral erosion. Conducting a longitudinal profile survey of a stream and establishing permanent cross sections can be used to document changes in the streambed over time (Harrelson et al. 1994, Rosgen 1996). The longitudinal profile survey is important for documenting changes in slope of the water surface, the channel bed, floodplain, and terraces (Harrelson et al. 1994). Cross sections are elevation transects that are surveyed perpendicular across the stream from bank to bank. Each end of the cross section is monumented with a stationary feature, such as rebar (Lisle and Eads 1991). They are useful in documenting changes in streambed elevation and stream bank changes (Lisle and Eads 1991, Harrelson et al. 1994). Scour chains can also be used to measure the amount of scour of fill occurring in a streambed over a period of time (Lisle and Eads 1991, Laronne et al. 1994). Scour chains, i.e., anchored galvanized chains, are placed perpendicular across the streambed, and locations of the scour chains are surveyed as features in the monumented cross sections. Scour is measured by counting the number of chain links exposed over time, and fill by determining the 
thickness of the sediment layer deposited on top of the originally exposed links (Lisle and Eads 1991).

Champoux et al. (2003) compared the longitudinal profiles of Lawrence Creek, Wisconsin over a 30 year period. In 1963, a stream habitat enhancement project was implemented and included the installation of bank deflectors, boulders, and woody debris. Longitudinal profiles were surveyed in 1963, just after the work had been completed and then three years later in 1966. Lawrence Creek was resurveyed in 1999. The habitat in Lawrence Creek improved significantly in the three years following habitat improvement, however, it declined in the 30 year period following.

Wolman (1987) monitored the movement of different size sediment particles and the changes in stream morphology of Baisman Run, Maryland between 1964-1968. Seven longitudinal profiles were surveyed over the four-year period. Downstream dislocation of gravel accompanied upstream migration of headcuts. Headcuts were most often formed during high flows, but the longitudinal profile flattened during a drought year. The surveys showed that several bars of coarse gravel moved successively as single units (Wolman 1987).

In the 1940s the Soil Conservation Service surveyed 37 cross sections in the Galena River basin in southwest Wisconsin and northern Illinois, 23 of these were resurveyed in 1979 (Magilligan 1985). Soil conservation practices were implemented in the watershed between the two time periods. Bankfull channel capacity decreased between the two time periods, indicating that channel forming flood discharge was greater prior to the 1940s. The wide channels upstream and narrow channels downstream surveyed in the 1940s became more uniform. This was an expected adjustment in response to the improved land use practices that reduced sediment load and variability of flooding (Magilligan 1985). 
During 1999-2000, Colosimo (2002) resurveyed 24 stream cross sections in Gynn Falls watershed, Baltimore, Maryland. The original cross sectional surveys were conducted between 1985-1987. The sites were divided into urban side tributaries $(\mathrm{n}=6)$, rural side tributaries $(\mathrm{n}=12)$, urban mainstream $(n=3)$, and rural mainstream $(n=3)$. Seven of the 24 were considered in the aggradation stage. The streams had narrowed and cross section areas were decreasing in response to increased water and sediment discharge. These seven sites had lateral point bars of deposited sediment. Nine early erosion sites were characterized by the gradual removal of fine sediments on lateral and point bars between the two surveys. The erosion led to gravel and cobble exposure at low to middle bar elevations. Five of the sites were termed late erosional and had increased channel area between the two sampling periods. At three of these the channel width decreased, however area increased due to channel incision (Colosimo 2002).

Urbana and Rhoades (2003) compared channelized and natural stream reaches within the Embarrass River in Illinois. Stream cross sections were surveyed in stream reaches before and after channelization, and before and after a sustained bankfull flow. They found most channel segments were stable. The greatest influence on the change in channel location throughout the Embarrass watershed was straightening of the channel, which caused slight net aggradation. This was attributed to an increase in sediment influx resulting from erosion of exposed, unvegetated channel banks.

Grabel and Harden (2006) studied the impacts of human induced changes to the channel of Second Creek, in Knoxville, Tennessee. Changes included deliberate channel realignment, and channelization of some reaches through culverts and cement lined channels. In a four year study from 1997 to 2001, they found no upstream-downstream trend of erosion or deposition, however, cross sections indicated a downstream trend of increasing width and area. Channel 
widening resulting from bank erosion was the dominant accommodation to higher volume peak flows in Second Creek. Erosion was restricted to unarmored banks, and aggradation most often occurred in cement culverts and concrete lined channels.

Hammer (1972) found an original increase in sediment followed by increase in discharge, downcutting and channel widening in an urbanizing watershed in eastern Pennsylvania. In another study of Pennsylvania streams (Pizzuto et al. 2000), paired urban and rural catchments did not differ in slope of bed or mean bankfull depth. However, bankfull width was larger for urban channels. Similar results were found by Hollis and Luckett (1976) in southeast England, Neller (1988) in New South Wales in Australia, and Henshaw and Booth (2000) in Puget Sound in Washington.

In summary, this literature review supports Chapters $2-6$ of this dissertation. This dissertation documents a variety of methods used to assess the impacts of highway construction in the Lost River watershed, West Virginia. In Chapter 2, I describe the methods to design a new sediment sampling device that can be used for repeat measures of sediment without continual disturbance of the streambed. Chapter 3 provides results from a laboratory flume study that compares my new sediment sampler design with other methods of measuring stream sedimentation. I compared my sampler to Whitlock-Vibert boxes (Wesche et al. 1989) and core samplers (McNeil and Ahnell 1964; Platts et al. 1989).

In Chapter 4, I monitored sedimentation using the in-stream sediment sampler at paired sites upstream and downstream of highway construction on two tributaries of the Lost River, Sauerkraut Run and an unnamed tributary. I also monitored changes in the benthic macroinvertebrate communities using an index of biotic integrity, the West Virginia Stream Condition Index (U. S. EPA 2000). I chose benthic macroinvertebrates as our biological 
indicator because they are sensitive to environmental changes (degradation and improved stream health), and provide an indication of long-term changes in water quality and habitat (Johnson et al. 1993). Chapter 5 documents changes in the stream channel of Sauerkraut Run in response to highway construction and high flow events. Changes were evaluated using cross section and longitudinal profile surveys.

In Chapter 6 I assessed the impacts of construction of a segment of Corridor $\mathrm{H}$ in the Lost River watershed by monitoring benthic macroinvertebrate communities and water quality, before, during, and after highway construction at paired upstream and downstream sites from 1997 through 2007. The variety of methods used in these five chapters allowed better understanding of how various impacts of highway construction, and environmental variables, such as high flows, interact to influence the biota and habitat of streams. 


\section{Literature Cited}

Allen, J. D. 1995. Stream Ecology: Structure and function of running waters. Chapman and Hall, Oxford, Great Britian.

Angermeier, P. L., A. P. Wheeler, and A. E. Rosenberger. 1994. A conceptual framework for assessing impacts of roads on aquatic biota. Fisheries 29:19-29.

Albanese, B., and G. Matlack. 1998. Environmental Auditing: Utilization of parking lots in Hattiesburg, Mississippi, USA, and impacts on local streams. Environmental Management 24: 265-271.

Barton, B. A. 1977. Short-term effects of highway construction on the limnology of a small stream in southern Ontario. Freshwater Biology 7: 99-108

Berkman, H. E. and C. F. Rabeni. 1987. Effects of siltation on stream fish communities. Environmental Biology of Fishes. 18:285-294.

Beschta, R. L. 1978. Long-term patterns of sediment production following road construction and logging in the Oregon coast range. Water Resources Research 14:1011-1016.

Beschta, R. L., 1996. Suspended sediment and bedload. Pages 123-144 in F. R. Hauer and G. A. Lambert, eds. Methods in stream ecology. Academic Press, San Diego, California, USA.

Brusven, M. A. and K. V. Prather. 1974. Influence of stream sediment on distribution of macrobenthos. Journal of Enthomological of Society British Coloumbia 71:25-32.

Burns, J. W. 1972. Some effects of logging and associated road construction on Northern California streams. Transactions of the American Fisheries Society 101: 1-16.

Champoux, O., P. M. Biron, and A. G. Roy. 2003. The long term effectiveness of fish habitat restoration practices: Lawrence Creek, Wisconsin. Annals of the Association of American Geographers 93:42-54. 
Chrisholm, J. L., and S. C. Downs. 1978. Stress and recovery of aquatic organisms as related to highway construction along Turtle Creek, Boone County, West Virginia. U.S. Geological Survey Water Supply Paper 2055, Washington, DC.

Cline, L. D., R. A. Short, and J. V. Ward. 1982. The influence of highway construction on the macroinvertebrate and epilithic algae of a high mountain stream. Hydrobiologia 96:149159.

Colosimo, MF. 2002. Physical and biological stream changes in an urbanizing watershed:

Gwynns Falls, Maryland. Doctoral Dissertation. Johns Hopkins University, Baltimore, Maryland.

Colosimo, M. F., and P. R. Wilcock. 2007. Alluvial sedimentation and erosion in an urbanizing watershed, Gwynns Falls, Maryland. Journal of the American Water Resources 43: 499521.

Cummins, K. W. and R. W. Merritt. 1996. Ecology and distribution of aquatic insects. Pages 7486 in Merritt, R. W. and K. W. Cummins, eds. An Introduction to the Aquatic Insects of North America (3rd ed). Kendall/Hunt Publishing Company. Dubuque, Iowa.

Duck, R. W. 1985. The effect of road construction on sediment deposition in Loch Earn, Scotland. Earth Surface Processes and Landforms 10:401-406.

Eaglin, G. S., and W. A. Hubert. 1993. Effects of logging and roads on substrate and trout in streams of the Medicine Bow National Forest, Wyoming. North American Journal of Fisheries Management 13:844-846.

Gardener, M. B. 1981. Effects of turbidity on feeding rates and selectivity of bluegills. Transactions of the American Fisheries Society 110:446-450. 
Grabel, J. L., and C. P. Harden. 2006. Geomorphic response of an Appalachian valley and ridge stream to urbanization. Earth Surface Processes and Landforms 31: 1707-1720

Graf, W. L. 1975. The impact of suburbanization on fluvial geomorphology. Water Resources Research 11: 690-692.

Grost, R. T., W. A. Hubert, and T. A. Wesche. 1991. Field comparison of three devices used to sample substrate in small streams. North American Journal of Fisheries Management 11:347-351.

Hammer T. R. 1972. Stream channel enlargement due to urbanization. Water Resources Research 8: 1530-1540.

Harrelson, C. C., C. L. Rawlins, and J. P. Potyondy. 1994. Stream channel reference sites: an illustrated guide to field techniques. Gen. Tech. Rep. RM-245. U. S. Department of Agriculture, Forest Service, Rocky Mountain Forest and Range Experiment Station. Fort Collins, CO.

Hames, D.S., B. Conrad, A. Plues, and D. Smith. 1996. Field comparison of the McNeil sampler with three shovel-based methods used to sample spawning substrate composition in small streams. Northwest Indian Fisheries Commission, Report TFW-AM-9-96-005.

Henley, W. F., M. A. Patterson, R. J. Neves, and A. Dennis Lemley. 2000. Effects of sedimentation and turbidity on lotic food webs: A concise review for natural resource managers. Reviews in Fisheries Science 8: 125-139.

Henshaw, P. C. and D. B. Booth. 2000. Natural restabilization of stream channels in urban watersheds. Journal of the American Water Resources Association 36:1219-1236.

Hollis, G. E. and J. K. Luckett. 1976. The response of natural river channels to urbanization: two case studies from southeast England. Journal of Hydrology 30:351-363. 
Johnson, P. A. 2002. Incorporating road crossings into stream and river restoration projects. Ecological Restoration 20: 270-277.

Johnson, P. A. 2006. Physiographic characteristics of bridge-stream interactions. River Research and Applications 22: 617-630.

Johnson, R. K., T. Wilderholm, and D. M. Rosenberg. 1993. Freshwater biomonitoring using individual organisms, population, and species assemblages of benthic macroinvertebrates. Pages 40-158 in D. M. Rosenberg and V. H. Resh, eds., Freshwater Biomonitoring and Benthic Macroinvertebrates. Chapman Hall, New York, New York.

Jones, E. B.D. III, G. S. Helfman, J. O. Harper, and P. V. Bolstad. 1999. Effects of riparian forest removal on fish assemblages in southern Appalachia streams. Conservation Biology 13:1454-1465.

Jones, J. A., F. J. Swanson, B. C. Wemple, and K. U. Snyder. 2000. Effects of roads on hydrology, geomorphology, and disturbance patches in stream networks. Conservation Biology 14:76-85.

Judy, R. D., Jr., P. N. Seeley, T. M. Murray, S. C. Svirsky, M. R. Whitworth, and L. S. Ischinger. 1984. 1982 National Fisheries Survey, Volume I. Technical report: initial findings. U. S. Fish and Wildlife Service, FWS-OBS-84/06, Washington, D.C.

Kaller, M.D., and K. J. Hartman. 2004. Evidence of a threshold level of fine sediment accumulation for altering benthic macroinvertebrate communities. Hydrobiologia 518: 95-104.

King, R. R., K. T. Nunnery, and C. J. Richardson. 2000. Macroinvertebrate assemblage response to highway crossings in forested wetlands: implications for biological assessment. 2000. Wetlands Ecology and Management 8:243-256. 
King, D. L. and R. C. Ball. 1965. The influence of highway construction on a stream. Michigan State University, Agriculture Experiment Station, East Lansing. Research Report No. 19: $4 \mathrm{pp}$.

Lachance, S. and M. Dube. 2004. A new tool for measuring sediment accumulation with minimal loss of fines. North American Journal of Fisheries Management 24: 303-310.

Lamberti, G. A. and M. B. Berg. 1995. Invertebrates and other benthic features as indicators of environmental change in Juday Creek, Indiana. Natural Areas Journal 15:249-258.

Laronne, J. B., D. N. Outhet, P. A. Carling, and T. J. McCabe. 1994. Scour chain deployment in gravelbed rivers. Catena 22: 299-306.

Lemly, D. A. 1982. Modification of benthic insect communities in polluted streams: combined effects of sedimentation and nutrient enrichment. Hydrobiologia 87:229-245.

Lisle, T. E., and R. E. Eads. 1991. Methods to measure sedimentation of spawning gravels. United States Department of Agriculture, Forest Service, Pacific Southwest Research Station Berkley, CA, USA. Research Note PSW-411.

Magilligan, F. J. 1985. Historical floodplain sedimentation in the Galena River Basin, Wisconsin and Illinois. Annals of the Association of American Geographers 75:583-594.

McNeil, W. J. and W. H. Ahnell. 1964. Success of pink salmon spawning relative to size of spawning bed materials. U. S. Fish and Wildlife Service, Special Scientific Report Fisheries No. 469, Washington, D. C.

Minshall, G. A. 1984. Aquatic insect-substratum relationships. Pages 358-400 in Resh, V. H., and D. M. Rosenberg, eds. The Ecology of Aquatic Insects. Praeger Publishers, New York, USA. 
Neller, R. J. 1988. A comparison of channel erosion in small urban and rural catchments, Armidale, New South Wales. Earth Surface Processes and Landforms 13:1-7.

O’Conner, W. C. K., and T. E. Andrew. 1998. The effects of siltation on Atlantic salmon, Salmo salar L., embryos in the River Bush. Fisheries Management and Ecology 5:393401.

Platts, W. S., R. J. Torquemada, M. L. McHenry, and C. K. Graham. 1989. Changes in salmon spawning and rearing habitat from increased delivery of fine sediment to the South Fork Salmon River, Idaho. Transactions of the American Fisheries Society 118:274-283.

Rabeni, C. F. and M. A. Smale. 1995. Effects of siltation on stream fish and the potential mitigating role of the buffering zone. Hydrobiologia 303:211-219.

Richardson, E.V., and Davis, S.R. 2001. Evaluating scour at bridges. Fourth edition: Federal Highway Administration Hydraulic Engineering Circular No. 18, FHWA-IP-90-017.

Richter, B. D., D. P. Braun. M. A. Mendelson, and L. L. Master. 1997. Threats to imperiled freshwater fauna. Conservation Biology 11: 1081-1093.

Rosgen, D.L. 1996. Applied River Morphology. Wildland Hydrology Books, Pagosa Springs, Colorado, USA.

Scrivener, J. C., and M. J. Brownlee. 1989. Effects of forest harvesting on spawning gravel and incubation of chum (Oncorhynchus keta) and coho salmon (O. kisutch) in Carnation Creek, British Columbia. Canadian Journal of Aquatic Sciences 46:681-696.

Schueler, T. R. 2000. Comparison of forest, urban, and agriculture streams in North Carolina. Pages 103-106 in T. R. Schueler and H. K. Holland, eds. The Practice of Watershed Protection. Center for Watershed Protection, Ellicott City, Maryland.

Schumm, S. A. 1977. The Fluvial System. John Wiley and Sons, New York, New York, USA. 
Smith, M. E. and J. L. Kaster. 1983. Effect of rural highway runoff on stream benthic macroinvertebrates. Environmental Pollution 32:157-170.

Sweka, J. A., and K. J. Hartman. 2001. Influence of turbidity on brook trout reactive distance and foraging success. Transactions of the American Fisheries Society 130:138-146.

Trimble, S. W. 1997. Contribution of stream channel erosion to sediment yield from an urbanizing watershed. Science 278:1442-1444.

Urbana, M. A., and B. L. Rhoads. 2003. Catastrophic human-induced change in stream-channel planform and geometry in and agricultural watershed, Illinois, USA. Annals of the Association of American Geographers 93:783-796.

U. S. EPA (United States Environmental Protection Agency). 1990. National water quality inventory: 1988 report to Congress. EPA Report 440490003, Washington, D.C.

U. S. EPA (United States Environmental Protection Agency). 1994. National water quality inventory: 1992 report to Congress. EPA Report 841R94001, Washington, D.C.

U. S. EPA (United States Environmental Protection Agency). 1996. Quality Criteria for Water 1986. EPA 440/5-86-001. Office of Water Regulations and Standards, Washington, D.C.

U. S. EPA (United States Environmental Protection Agency). 1997. Monitoring Water Quality. EPA 841-B-97-003. Office of Water Regulations and Standards, Washington, D.C.

U.S. EPA (United States Environmental Protection Agency). 2000. A stream condition index for West Virginia wadeable streams, Region 3 Environmental Services Division. Prepared by Tetra Tech, Inc. July 21, 2000. 
Ward, A., D. Mecklenburg, J. Mathews, D. Farver. 2002. Sizing stream setbacks to help maintain stream stability. American Society of Agricultural Engineers Meeting Paper No. 022239. St. Joseph, Michigan:ASAE.

Waters, T. F. 1995. Sediment in streams: sources, biological effects, and control. American Fisheries Society, Monograph 7, Bethesda, Maryland.

Wellman, J. C., D. L. Combs, and S. B. Cook. 2000. Long-term impacts of bridge and culvert construction or replacement on fish communities and sediment characteristics of streams. Journal of Freshwater Ecology 15(3):317-328.

Wesche, T. A., D. W. Reiser, V. R. Hasfurther, W. A. Hubert, and Q. D. Skinner. 1989. New technique for measuring fine sediment in streams. North American Journal of Fisheries Management 9:234-238.

West Virginia Department of Transportation. 2002. Corridor H: West Virginia Division of Highways, West Virginia Department of Transportation. www.wvcorridorh.com.

Wohl, N. E. and R. F. Carline. 1996. Relations among riparian grazing, sediment loads, macroinvertebrates, and fishes in three central Pennsylvania streams. Canadian Journal of Fisheries and Aquatic Sciences 53:260-266.

Wohl, E. E. 2000. Mountain Rivers. American Geophysical Union Press, Washington, D.C.

Wohl, E. E. 2006. Human impacts to mountain streams. Geomorphology 79 (2006) 217-248.

Wolman, M. G. 1967. Cycle of Sedimentation and Erosion in Urban River Channels. Geografiska Annaler 49(A): 385-395.

Wolman, M. G. 1987. Sediment movement and knickpoint behavior in a small piedmont drainage basin. Geografiska Annaler. Series A, Physical Geography 69(1):5-14. 
Wood, P. J. and P. D. Armitage. 1997. Biological effects of fine sediment in the lotic environment. Environmental Management 21:203-217. 


\section{Chapter 2 - A New Sampler Design for Measuring Sedimentation in Streams ${ }^{1}$}

${ }^{1}$ This chapter is written in the style of the North American Journal of Fisheries Management and is published as -

Hedrick, L.B., S.A. Welsh, and J.D. Hedrick. 2005. A new sampler design for measuring sedimentation in streams. North American Journal of Fisheries Management 25: 238-244. 


\begin{abstract}
Sedimentation alters aquatic habitats and negatively affects fish and invertebrate communities, but is difficult to quantify. To monitor bed load sedimentation, we designed a sampler with a 10.16-cm PVC coupling and removable sediment trap. We conducted a trial study of our samplers in riffle and pool habitats upstream and downstream of highway construction on a first-order Appalachian stream. Sediment samples were collected at three 6week intervals, dried, and separated into 5 size classes with nested sieves (US Standard Sieve No. 4, 8, 14, and 20). Downstream sediment accumulated in size classes 1, 2, and total amount accumulated was significantly greater during all three sampling periods $(P \leq 0.05)$. Size class 3 and class 4 had significantly greater amounts of sediment for the first two sampling periods $(P \leq$ 0.005) at the downstream site. Differences between upstream and downstream sites narrowed during the 5-month sampling time period. This likely reflects changes in site conditions including the addition of more effective sediment control measures after the first six week period of the study. The sediment sampler design allowed for long-term placement of traps without continual disturbance of the streambed, and was successful at providing repeat measures of sediment at paired sites.
\end{abstract}




\section{Introduction}

Stream sedimentation can occur as a natural process, and is necessary for bank and bar formation. However, excessive stream sedimentation resulting from anthropogenic land disturbances, such as gravel mining (Brown et al. 1998), agriculture (Crawford and Lenat 1989; Dennehy et al. 1998; Wasler and Bart 1999), forestry practices (Beschta 1978; Scrivener and Brownlee 1989; Eaglin and Hubert 1993), and construction of roads (King and Ball 1965; Beschta 1978; Platts et al. 1989) can be detrimental. Sedimentation alters community composition, and decreases survival, population size, and reproductive success of fishes (Scrivener and Brownlee 1989; Rabeni and Smale 1995; Jones et al. 1999), amphibians (Corn and Bury 1989; Welsh and Ollivier 1998) and benthic invertebrates (King and Ball 1965; Cline et al. 1982; Henley et al. 2000). Understanding the effects of land disturbances on aquatic organisms requires monitoring (often long-term) and measurement of sedimentation. Most sediment-monitoring approaches, however, are difficult, time consuming and expensive for use in repeat-sampling designs and long-term studies with frequent measurements of sediment.

Traditional techniques for measuring sediment composition in streams include core sampling (McNeil and Anhell 1964; Platts et al. 1989; Wellman et al. 2000) and visual estimation along transects (Platts et al. 1989; Eaglin and Hubert 1993). Core sampling is labor and equipment intensive, and disturbs a portion of the streambed during each use (Berkman and Rabeni 1987; Platts et al. 1989). Core sampling is usually used for a single or annual measurement of sediment, but is not an effective method for repeated sampling over a long time interval (e.g., monthly sampling) due to labor intensiveness and cost. The Whitlock-Vibert box, originally designed for incubation of various species of trout eggs, is another method to monitor sedimentation (Wesche et al. 1989; Garrett and Bennett 1996; and Clarke and Scruton 1997). 
However, these box samplers allow loss of sediment during retrieval from the streambed, and require disturbance of the streambed during each deployment.

Our objectives were to 1) design an inexpensive sampler that collects multiple sediment samples over long time periods, 2) to use the new sampler in a trial study to monitor roadconstruction sediments in Sauerkraut Run, a first-order Appalachian stream, and 3) to conduct an in-stream comparison study of the sampler to Whitlock-Vibert boxes (Wesche et al. 1989).

\section{Sampler Design}

Our sediment sampler consisted of two parts, a base and a trap. The base was constructed from 10.16-cm (4-in) schedule 40 PVC coupling with a height of $9.53 \mathrm{~cm}$ (3.75 in). The top half of the coupling was ground out using a $115-\mathrm{mm} \times 6-\mathrm{mm} \times 22.2-\mathrm{mm}$ (4.5-in x 0.25-in x 0.75-in) metal grinding wheel attached to a $0.33 \mathrm{hp}, 1,725 \mathrm{rpm}$, electric motor. This was done to allow the trap to slide freely in and out of the base. The trap was constructed by fitting (with silicon) a 10.16-cm (4 in) insert cap onto a 5-cm piece of 10.16-cm (4 in) schedule 40 PVC pipe (Figure 1).

During sampler deployment, the base was embedded in the substrate with the base top flush with the substrate. Next, the trap, filled with 12 to $25 \mathrm{~mm}$ diameter white gravels, was inserted into the base (Figure 1). White gravels were used because they were inexpensive, and made the samplers easily identifiable from the surrounding substrate. When retrieved, white gravels that had been previously placed in the samplers could be removed, allowing us to determine the amount of larger substrate that had settled in the traps. At subsequent sampling events, the trap was removed and replaced, but the base remained embedded in the streambed. 
The two-part design allows users to disturb the streambed only once at the onset of deployment, and prevents accidental addition or loss of sediment during deployment or retrieval.

\section{Methods}

Sauerkraut Run, a tributary of the Lost River located in Hardy County, West Virginia, was the site of our initial trial test with the sediment samplers. Construction of a four-lane highway across the stream began in May 2002. Before our study began, a construction crew placed a culvert and earthen bridge in Sauerkraut Run. The culvert was located approximately $150 \mathrm{~m}$ upstream from the confluence of Sauerkraut Run with the Lost River, and $100 \mathrm{~m}$ upstream from a bridge crossing for state route 55 . The bankfull width at the upstream site was approximately $8.2 \mathrm{~m}$, and the stream cross sectional area was $4.4 \mathrm{~m}^{2}$. The bankfull width at the downstream site was approximately $5.5 \mathrm{~m}$, and the stream cross sectional area was $2.4 \mathrm{~m}^{2}$. Sauerkraut Run had a slope of 0.02 .

We placed 12 sediment samplers $250 \mathrm{~m}$ upstream from the construction site, and 12 samplers $70 \mathrm{~m}$ downstream from the construction site. There was a limited stream reach between the construction site and the confluence of Sauerkraut Run with the Lost River (150 m). Therefore, the samplers were placed $70 \mathrm{~m}$ downstream of the site, and upstream of the current bridge crossing. The upstream site was chosen ( $250 \mathrm{~m}$ upstream from construction) because it was an undisturbed section of stream with a good riparian zone, and a dirt road paralleling Sauerkraut Run veered away from the stream at this point. Six samplers were placed in riffle and six in pool habitat. Samplers were placed randomly wherever excavation to a depth $0 \mathrm{f} 10 \mathrm{~cm}$ could be done without removing large cobble and boulder material that would have caused a substantial disturbance of the streambed. Samplers in the riffle section were placed along the 
thalweg to prevent dewatering during low flows. At the end of three 6-week periods (31 August 2002, 11 October 2002, and 21 December 2002), we removed and replaced sediment traps, and emptied sediments into watertight containers for processing in the lab (Figure 1). We measured stream flow (cfs, Marsh-McBirney flow meter), and water depth (mm) at each sampler location. During one 6-week period Whitlock-Vibert boxes anchored to rebar and filled with gravels between 12 to $25 \mathrm{~mm}$ in diameter were buried adjacent to sediment traps at the upstream Sauerkraut Run site (for detailed methods see Wesche et al. 1989). The 12 Whitlock-Vibert boxes were collected along with the sediment samplers.

In the laboratory, we removed white gravels greater than $12 \mathrm{~mm}$ in diameter from the samples. We allowed the remaining sediments to settle and removed clear water. We dried sediment samples at $75{ }^{\circ} \mathrm{C}$ for 36 to $48 \mathrm{~h}$ until a constant weight. We sieved each sample (US Standard Sieve No. 4, 8, 14, and 20) into five size classes (class 1: greater than $4.70 \mathrm{~mm}$; class 2: 2.28 to $4.70 \mathrm{~mm}$; class 3: 1.40 to $2.28 \mathrm{~mm}$; class $4: 0.98$ to $1.40 \mathrm{~mm}$; and class 5: less than 0.98 $\mathrm{mm}$ ). Sediment for each size class was weighed to the nearest $0.0001 \mathrm{~g}$ (Sargent-Welch, SWA 200-DR). The five size classes were summed to represent a sixth (total) size class.

We compared the amount of sediment accumulated in samplers placed upstream and downstream, and the percent of material accumulated in samplers and Whitlock-Vibert boxes. Analysis of variance (ANOVA) was used to determine significant differences in the amount of sediment accumulated by site, and gear type $($ alpha $=0.05)$.

\section{Results}

We collected sediment samples three times throughout the study period. Average stream discharge at the time of sampler collections in August, October, and December was 0.028, 0.003, 
and $0.15 \mathrm{~m}^{3} / \mathrm{s}$, respectively. The average depth of riffle samplers at time of collection for the three 6-week periods ranged from 45 to $203 \mathrm{~mm}$, and average velocity at depth of samplers ranged from 0.12 to $0.45 \mathrm{~m} / \mathrm{s}$ (Table 1). The average depth of pool samplers at time of collection ranged from 172 to $351 \mathrm{~mm}$, and average velocity at depth of samplers ranged from 0.006 to $0.15 \mathrm{~m} / \mathrm{s}$ (Table 1).

Of the 36 samples that could be collected per site, 29 samples were used for analysis from the upstream Sauerkraut Run site, and 24 samples from the downstream site. The remaining samples were unusable due to local scour or inability to locate the sampler. We deployed samplers during low stream flow, and localized scour during high flow flushed seven of the sediment traps. Samples from flushed traps were collected but were not used in analysis. The study stream experienced high bed load movement, and 12 samplers were buried in depositional areas. Buried samplers were found at a later date. However, we did not use samples collected from traps in buried samplers in analysis.

There was a significantly greater amount of material accumulated at the downstream site during all three sampling periods for size class 1 , class 2 , and total $(P \leq 0.05$; Figure 2$)$. Size class 3 and class 4 had significantly greater amounts of sediment for the first two sampling periods $(P \leq 0.005)$ at the downstream site. However, during the December sampling period, the difference was not significant between upstream and downstream sites for class $3(P=0.06)$ and class $4(P=0.18)$. The amount of material accumulated in size class 5 was not significantly different between upstream and downstream sites during October $(P=0.54)$ and December $(P=$ $0.06)$.

Twelve Whitlock-Vibert boxes were collected in October 2002 along with the 12 sediment samples at the upstream site on Sauerkraut Run. The Whitlock-Vibert boxes were 
larger, and could hold a greater volume of sediment. Therefore we compared the percent of material accumulated in each size class. Sediment samplers collected in riffles $(P=0.0001)$ and pools $(P=0.0055)$ had a greater mean percentage of material accumulated in size class 1 than the adjacent Whitlock-Vibert boxes (Figure 3). The percent of material accumulated in class 3 $(P=0.0004)$ and class $4(P=0.0022)$ was greater in the Whitlock-Vibert boxes in riffles, and there was no difference in the amount of sediment accumulated in class $2(P=0.626)$ and class 5 $(P=0.462)($ Figure 3$)$. The mean percent of material accumulated in class 3 was significantly greater in the Whitlock-Vibert boxes for pool samples $(P=0.0166)$, all other size classes were not significantly different (Figure 3).

\section{Discussion}

Our sampling device was designed for long term monitoring of paired sites in streams impacted by road construction. We found our sediment sampler was effective for this purpose. This invention allows users to monitor temporal changes in sediment, where the streambed is disturbed only once during initial deployment, limiting impacts on the study. Core sampling and the Whitlock-Vibert box methods disturb the streambed when retrieving or replacing samplers.

The base does not require additional anchoring as needed for Whitlock-Vibert boxes (Wesche et al. 1989). During the three six week periods, no sampler bases were lost, although some samples collected from traps were unusable for analysis due to localized scouring or becoming buried. After our initial trial, we added an anchoring device to the base. The anchoring device eliminated the possibility of pulling both the trap and base out of the streambed. This could happen if the trap became bound in the base due to small sediment filling in interstitial spaces between the trap and the base. The anchoring device was added to the base 
by drilling a $34.9 \mathrm{~mm}\left(1 \frac{3}{8} \mathrm{in}\right)$ hole through the bottom half of the coupling, and sliding a 25.4 $\mathrm{cm}$ piece of $2.54 \mathrm{~cm}$ (1 in) PVC through the hole (Figure 1).

We were unable to use 19 samples in analysis because the trap either was flushed, or the sampler was buried. Given hydrologic variability of headwater streams, researchers should compensate for expected sample losses through increasing the number of samplers. To increase recovery of samplers, researchers should photograph sampler locations and flag stream banks adjacent to samplers. We tied pink flagging to the piece of 10 -in PVC pipe inside the base and let it flow downstream of the sampler (Figure 1). This enabled us to find the samplers when we returned to the stream after 6-weeks.

Higher sedimentation was expected downstream of construction areas. Data supported differences between upstream and downstream areas, in part, because of a large effect size between upstream and downstream sample means. Differences between upstream and downstream sites narrowed during the 5-month sampling time period (Figure 2). There is graphically a decreasing trend for amount of sediment accumulated in class 1 , class 2 , and total for the downstream site. This likely reflects changes in site conditions during the five-month period. Effective sediment fencing was not constructed until after the first six-week period, and probably caused the large effect size between upstream and downstream sediment weights during the first sampling period. This large effect size allowed inference from relatively small sample sizes (i.e., three repeated measures on twelve samplers from each site). If these samplers are used for sedimentation studies without point-sources, or for longer-term studies that include pre-, during, and post-construction, then detection of tapering effect sizes will require larger sample sizes. 
The material accumulated in size class 1 (greater than $4.7 \mathrm{~mm}$ ) was significantly greater in the sediment samplers than in Whitlock-Vibert boxes. The largest of the openings on the Whitlock-Vibert boxes were $3.5 \mathrm{~mm}$ x $13 \mathrm{~mm}$, limiting the infiltration of larger sediment into the box. In contrast, the open design of our sediment sampler allowed all sizes of material to collect in the trap. The mean percentage of sediment in size class 3 was significantly greater in Whitlock-Vibert boxes in both pools and riffles, and the mean percentage of sediment in size class 4 was significantly greater in Whitlock-Vibert boxes in riffles. We physically buried the Whitlock-Vibert boxes in the streambed, and infiltration of material in these size classes may have occurred during this process. It is possible that our sampler filled up with larger substrate, and there was limited space for the addition of smaller substrate. The mesh limitations of the Whitlock-Vibert box may have allowed the box to capture a higher amount of smaller substrate (classes 3 and 4), possibly artificially overestimating the amount of small sediments.

The mean percentage of sediment accumulated in the size class less than $0.98 \mathrm{~mm}$ did not differ significantly between the Whitlock-Vibert boxes and our sediment samplers. Wesche et al. (1989) found that the mean percentage of fine sediment less than $0.85 \mathrm{~mm}$ did not differ significantly between Whitlock-Vibert boxes and McNeil core samples $(P \leq 0.05)$. Garrett and Bennett (1996) found similar results in increases of fine sediment less than $0.83 \mathrm{~mm}$ between Whitlock-Vibert boxes and surrounding gravels.

Our initial trial study was limited to a field test of our samplers. There are various aspects about the sampler design that have not yet been tested. It may be possible that the installation of a rigid structure in the streambed could create depositional conditions via reduced intragravel velocities. We attempted to minimize this effect by placing the sampler in a location where large gravel (close to the size of the sampler) had been excavated. In addition, our 
samplers had no openings "at-depth". We designed a sampler with "at-depth" openings created by drilling $6.35 \mathrm{~mm}$ holes in a $7 \mathrm{~cm}$ deep trap. However, we visually noticed sediment infiltrating into the trap during deployment, so we chose not to use this design in our trial study. These aspects of the sampler design need to be further tested in a laboratory setting. Also, experimental comparisons of our sampler design with the Whitlock-Vibert box and core sampling methods should be made.

\section{Management Implications}

Federal and state environmental regulations require sediment control measures during land development. To determine impacts from highway construction, however, managers need long-term sediment data, and a sampler design that quantifies sediment for time periods before, during, and after construction. Environmental impact studies are particularly needed for the Appalachian region, where sediment prevention from highway construction is difficult given mountainous areas, steep slopes, and cut and fill construction. Some sediment from construction enters streams, despite prevention efforts, such as fencing, hay bales, mulching, and ponds. Our sampler design is directly applicable to long-term evaluations of sediment prevention methods. Also, given the link between physical effects of stream sedimentation and biotic impacts (Waters 1995), long-term data collected from our sediment samplers could be used as covariates in studies linking sediment accumulation and changes in aquatic communities.

\section{Acknowledgements}

The West Virginia Division of Highways provided partial support for this research. Reference to trade names does not imply government endorsement of commercial products. 


\section{References}

Berkman, H. E. and C. F. Rabeni. 1987. Effects of siltation on stream fish communities. Environmental Biology of Fishes 18:285-294.

Beschta, R. L. 1978. Long-term patterns of sediment production following road construction and logging in the Oregon coast range. Water Resources Research 14:1011-1016.

Brown, A. V., M. M. Lytle, and K. B. Brown. 1998. Impacts of gravel mining on gravel bed streams. Transactions of the American Fisheries Society 127:979-994.

Clarke, K. D. and D. A. Scruton. 1997. Use of the Wesche method to evaluate fine-sediment dynamics in small boreal forest headwater streams. North American Journal of Fisheries Management 17:188-193.

Cline, L. D., R. A. Short, and J. V. Ward. 1982. The influence of highway construction on the macroinvertebrate and epilithic algae of a high mountain stream. Hydrobiologia 96:149159.

Corn, P. S. and R. B. Bury. 1989. Logging in western Oregon: Responses of headwater habitats and stream amphibians. Forest Ecology and Management 29:39-57.

Crawford, J. K. and D. R. Lenat. 1989. Effects of land use on the water quality and biota of three streams in the Piedmont province of North Carolina. U. S. Geological Survey. Water Resources Investigation Report 89-4007. Raleigh, North Ccarolina. 67 pp.

Dennehy, K. F., D. W. Litke, C. M. Tate, S. L. Qui, P. B. McMahon, B. W. Bruce, R. A. Kimbrough, and J. S. Heiny. 1998. Water Quality in the South Platte River Basin, Colorado, Nebraska, and Wyoming, 1992-1995. U. S. Geological Survey Circular 1167. 
Eaglin, G. S., and W. A. Hubert. 1993. Effects of logging and roads on substrate and trout in streams of the Medicine Bow National Forest, Wyoming. North American Journal of Fisheries Management 13:844-846.

Garrett, J. W. and D. H. Bennett. 1996. Evaluation of fine sediment intrusion into WhitlockVibert boxes. North American Journal of Fisheries Management 16:448-452.

Henley, W. F., M. A. Patterson, R. J. Neves, and A. D. Lemley. 2000. Effects of sedimentation and turbidity on lotic food webs: A concise review for natural resource managers. Reviews in Fisheries Science 8: 125-139.

Jones, E. B. D. III, G. S. Helfman, J. O. Harper, and P. V. Bolstad. 1999. Effects of riparian forest removal on fish assemblages in southern Appalachia streams. Conservation Biology 13:1454-1465.

King, D. L. and R. C. Ball. 1965. The influence of highway construction on a stream. Michigan State University, Agriculture Experiment Station, East Lansing. Research Report Number 19. 4 pp.

McNeil, W.F. and W.H. Ahnell. 1964. Success of pink salmon spawning relative to size of spawning bed materials. U. S. Fish and Wildlife Service Special Scientific ReportFisheries Number 469. Washington, D.C.

Platts, W. S., R. J. Torquemada, M. L. McHenry, and C. K. Graham. 1989. Changes in salmon spawning and rearing habitat from increased delivery of fine sediment to the South Fork Salmon River, Idaho. Transactions of the American Fisheries Society 118:274-283.

Rabeni, C. F. and M. A. Smale. 1995. Effects of siltation on stream fish and the potential mitigating role of the buffering zone. Hydrobiologia 303:211-219. 
Scrivener, J. C., and M. J. Brownlee. 1989. Effects of forest harvesting on spawning gravel and incubation survival of chum (Oncorhynchus keta) and coho salmon (O. kisutch) in Carnation Creek, British Columbia. Canadian Journal of Aquatic Sciences 46:681-696.

Wasler, C. A., and H. L. Bart, Jr. 1999. Influence of agriculture in in-stream habitat and fish community structure in Piedmont watersheds of the Chattahoochee River System. Ecology of Freshwater Fish 8 (4): 237-246.

Waters, T. F. 1995. Sediment in streams: sources, biological effects, and control. American Fisheries Society Monograph 7, American Fisheries Society, Bethesda, Maryland. 251 pp.

Wellman, J. C., D. L. Combs, and S. B. Cook. 2000. Long-term impacts of bridge and culvert construction or replacement on fish communities and sediment characteristics of streams. Journal of Freshwater Ecology 15:317-328.

Welsh, H. H. and L. M. Ollivier. 1998. Stream amphibians as indicators of ecosystem stress: A case study from California's redwoods. Ecological Applications 8:1118-1132.

Wesche, T. A., D. W. Reiser, V. R. Hasfurther, W. A. Hubert, and Q. D. Skinner. 1989. New technique for measuring fine sediment in streams. North American Journal of Fisheries Management 9:234-238. 
Table 1. Mean water depth $(\mathrm{mm})$ and stream velocity $(\mathrm{m} / \mathrm{s})$ at sampler locations in riffle and pool habitats at the time of sediment trap collections. Values in parentheses are standard deviations.

\begin{tabular}{|c|c|c|c|c|c|}
\hline & Date & $\begin{array}{l}\text { Riffle sampler depth } \\
(\mathrm{mm})\end{array}$ & $\begin{array}{l}\text { Riffle sampler velocity } \\
(\mathrm{m} / \mathrm{s})\end{array}$ & $\begin{array}{l}\text { Pool sampler depth } \\
(\mathrm{mm})\end{array}$ & $\begin{array}{l}\text { Pool sampler velocity } \\
(\mathrm{m} / \mathrm{s})\end{array}$ \\
\hline \multirow[t]{3}{*}{ Upstream } & 31 August 2002 & $45(17)$ & $0.25(0.13)$ & $214(34)$ & $0.006(0.001)$ \\
\hline & 11 October 2002 & $99(23)$ & $0.26(0.15)$ & $277(38)$ & $0.02(0.02)$ \\
\hline & 21 December 2002 & $203(46)$ & $0.29(0.24)$ & $335(92)$ & $0.15(0.13)$ \\
\hline \multirow[t]{3}{*}{ Downstream } & 31 August 2002 & $87(29)$ & $0.25(0.06)$ & $172(40)$ & $0.04(0.03)$ \\
\hline & 11 October 2002 & $144(35)$ & $0.12(0.12)$ & $225(49)$ & $0.05(0.03)$ \\
\hline & 21 December 2002 & $170(27)$ & $0.45(0.20)$ & $351(37)$ & $0.10(0.08)$ \\
\hline
\end{tabular}


Figure 1. Original and amended sediment sampler designs and steps in deploying and retrieving the sampler.

Figure 2. Mean dry weight (g) and standard error bars of sediment accumulated in each size class during the three six-week periods at sites upstream and downstream from highway construction. Mean values with different letters are significantly different $(P<0.05)$.

Figure 3. Mean dry weight (g) and standard error bars of sediment accumulated per size class (class 1: greater than $4.70 \mathrm{~mm}$; class 2: 2.28 to $4.70 \mathrm{~mm}$; class 3: 1.40 to $2.28 \mathrm{~mm}$; class $4: 0.98$ to $1.40 \mathrm{~mm}$; and class 5 : less than $0.98 \mathrm{~mm}$ ) in a six-week period in sediment samplers and adjacent Whitlock -Vibert boxes. Mean values with different letters within class are significantly different $(P<0.05)$. There are no among class comparisons. 
Hedrick et al. Figure 1

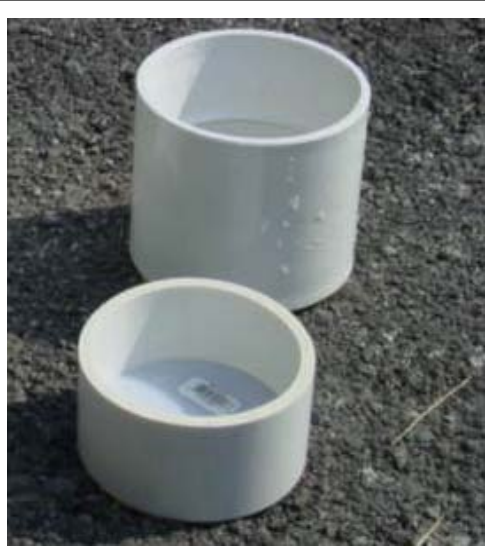

Step 1. Construct sampler - original design base constructed from $10.16-\mathrm{cm}$ union (height $=9.53 \mathrm{~cm}$ ), and trap constructed by fitting a $10.16-\mathrm{cm}$ insert cap onto a $5-\mathrm{cm}$ piece of $10.16-\mathrm{cm}$ pipe.

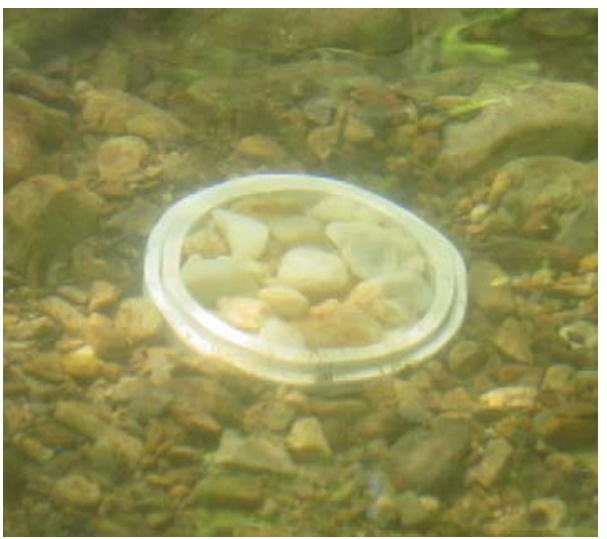

Step 3. Insert the sediment trap filled with gravels (12 to $25 \mathrm{~mm}$ ) into sampler base.

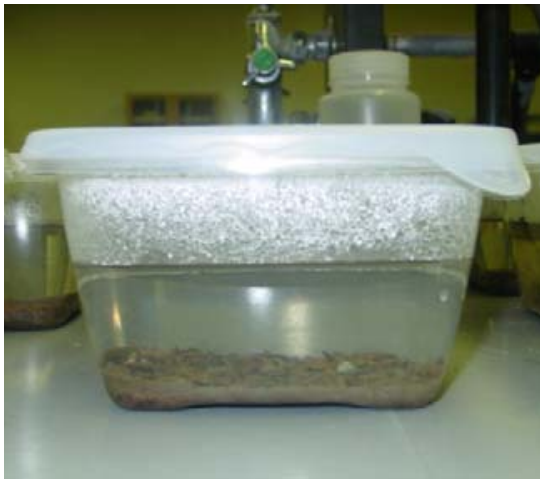

Step 4. Place sample in a water tight container and return to lab for processing.

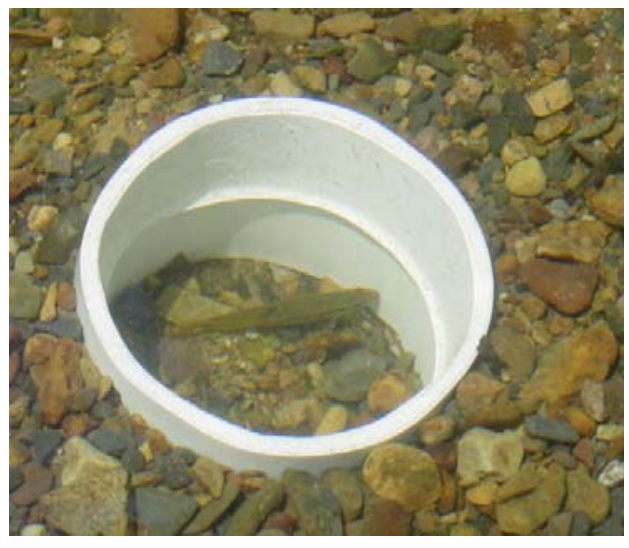

Step 2. Embed the sediment sampler base within stream substrate and flush with the streambed.

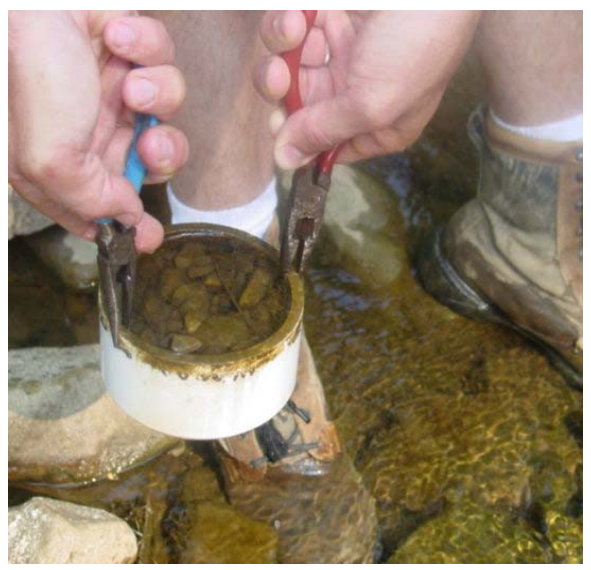

Step 4. After six weeks, return to sediment samplers. Using two pair of longnose pliers, remove sediment trap from base.

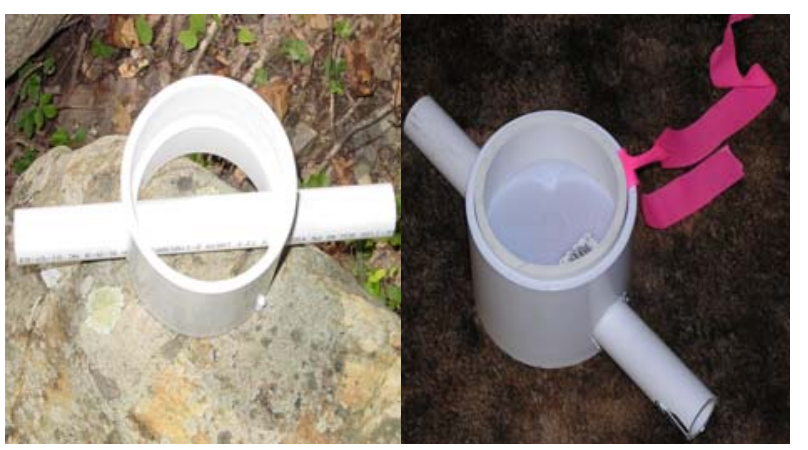

Modified sampler base with anchoring device constructed of a $25.4-\mathrm{cm}$ piece of $2.54-\mathrm{cm}$ schedule 40 PVC slid through $3.49-\mathrm{cm}$ hole in bottom half of base. 
Hedrick et al. Figure 2
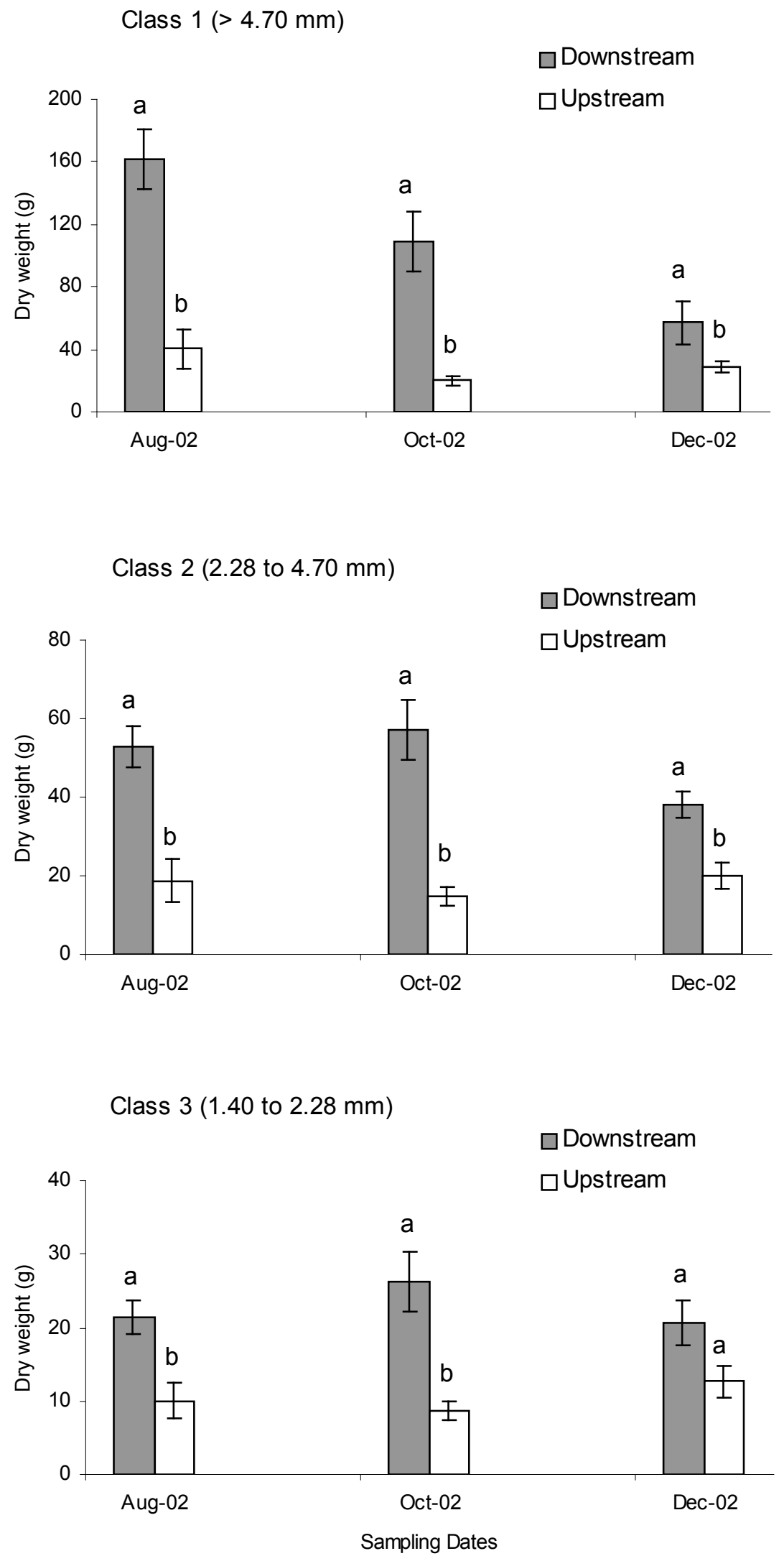
Hedrick et al. Figure 2
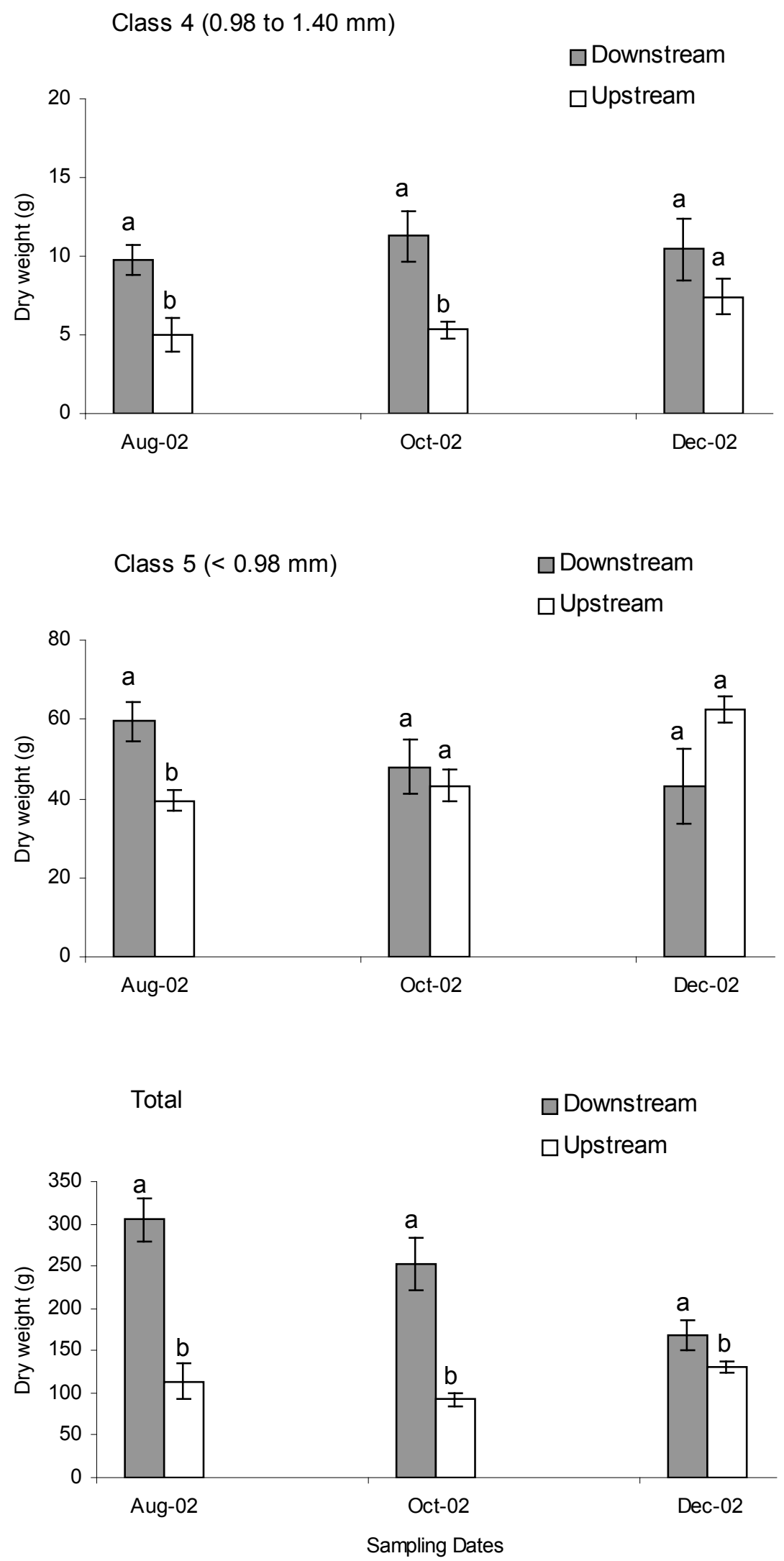
Riffle Samples

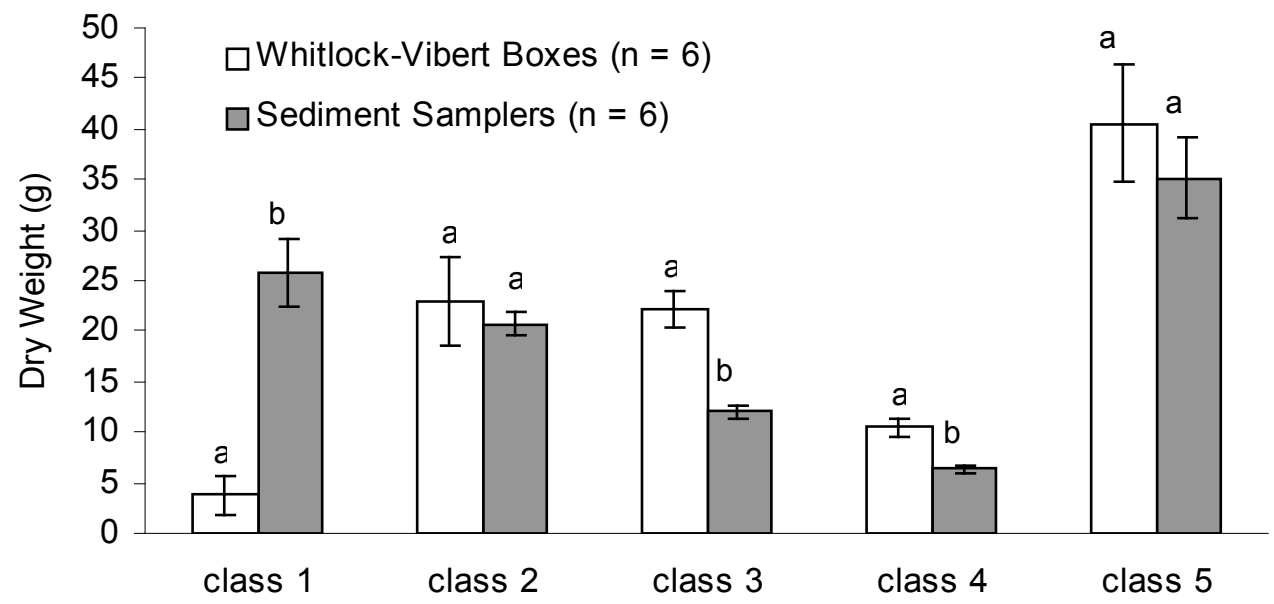

Pool Samples

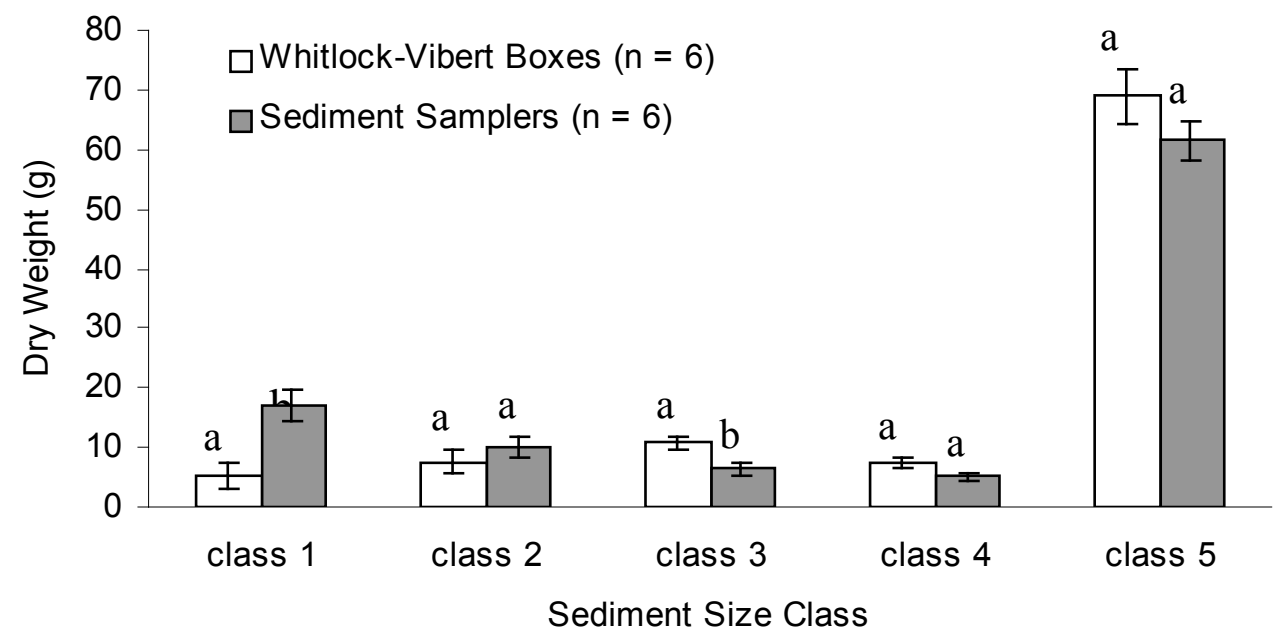




\section{Chapter 3 - Evaluation Of A New Sediment Sampling Device ${ }^{1}$}

${ }^{1}$ This chapter is written in the style of the Proceedings of the Annual Conference of the Southeastern Association of Fish and Wildlife Agencies, and is published as -

Hedrick, L. B., S. A. Welsh, J. T. Anderson, and J. D. Hedrick. In press. Evaluation of a new sediment sampling device. Proc. Annu. Conf. Southeast. Assoc. Fish and Wildl. Agencies : 


\begin{abstract}
$\underline{\text { Abstract }}$
A two-part sediment sampler (stationary base and removable trap) was designed for a long-term study of stream sedimentation associated with highway construction. Before the longterm study, a laboratory study in an experimental flume examined efficacies of our sampler and two other sediment samplers: a modified core sampler and Whitlock-Vibert boxes. Based on the flume experiment, the efficacy of our sediment sampler was consistent with that of core and Whitlock-Vibert samplers. The advantage of our two-part sediment sampler design is that it allows for repeated removal of sediment samples without continual disturbance of the streambed. Our sampler is designed for long term monitoring of streams impacted by sedimentation and not for characterization of stream substrate composition.
\end{abstract}

Key Words: flume experiment, rivers/streams, sediment, sediment traps, Whitlock-Vibert box

Proc. Annu. Conf. Southeast. Assoc. Fish and Wildl. Agencies : -

Sediments are one of the most common and geographically-widespread pollutants of stream systems (Judy et al. 1984; USEPA 1990; Richter et al. 1997). Although sedimentation is a natural process, stream systems are often negatively affected by anthropogenic sediment inputs from gravel mining (Brown et al. 1998), agriculture (Crawford and Lenat 1989; Dennehy et al. 1998; Wasler and Bart 1999), forestry practices (Beschta 1978; Scrivener and Brownlee 1989; Eaglin and Hubert 1993), and construction of roads (King and Ball 1965; Beschta 1978; Platts et al. 1989). Excessive stream sedimentation from anthropogenic land disturbances alters community composition, and decreases survival, population size, and reproductive success of fishes (Scrivener and Brownlee 1989; Rabeni and Smale 1995; Jones et al. 1999), amphibians 
(Corn and Bury 1989; Welsh and Ollivier 1998) and benthic invertebrates (King and Ball 1965;

Cline et al. 1982; Henley et al. 2000). Quantitative measures of stream sedimentation are useful to monitor and study anthropogenic impacts on stream biota; however, efficacies of sampling methods are not fully understood.

Stream sedimentation is measurable with multiple sampling methods. Traditional techniques for characterizing sediment composition in streams include core sampling (McNeil and Ahnell 1964; Platts et al. 1989; Wellman et al. 2000), the shovel method (Grost et al. 1991; Hames et al. 1996), and visual estimation along transects (Platts et al. 1989; Eaglin and Hubert 1993). Core sampling disturbs a portion of the streambed during each use (Berkman and Rabeni 1987; Platts et al.1989), and is usually used for single or annual measurements of sediment, as it is not effective for repeated sampling over long time intervals (e.g., monthly sampling) due to labor intensiveness and cost. The shovel method costs less than core sampling (Grost et al. 1991), but also results in heavy samples, and disturbs the substrate during each sampling event. To reduce labor and cost, several techniques for trapping sediment were developed (Wesche et al. 1989; Lachance and Dube 2004; Hedrick et al. 2005), but relatively few studies have addressed sampling efficacies among traditional and trap samplers (see Wesche et al. 1989).

We developed a sediment trap sampler with a two-part design, a stationary base and removable trap (Hedrick et al. 2005). Initially, we ran trial field tests with our sediment sampler and Whitlock-Vibert (W-V) boxes during a six week period (Hedrick et al. 2005). However, due to the unique design of our sampler, and the limited scope of the comparison trial, more information was needed to determine the effectiveness of our sediment sampler, and how it compares to other methods of sediment trapping. The objective of this study was to use a laboratory flume to test for differences in the amount of deposited sediment collected in our 
sediment sampler compared to a gear that samples the stream substrate (corer) and one that traps sediment (W-V boxes).

\section{Methods}

\section{Sampler Design}

Our sediment sampler consisted of two parts, a base and a trap. The base was constructed from 10.16-cm (4-in) schedule 40 PVC coupling with a height of $9.53 \mathrm{~cm}$ (3.75 in). The top half of the coupling was ground out to allow the trap to slide freely in and out of the base. The trap was constructed by fitting a 10.16-cm (4-in) insert cap onto a 5 -cm piece of 10.16-cm (4 in) schedule 40 PVC pipe (Figure 1; for details on sampler design see Hedrick et al. 2005). During sampler deployment in a stream, the base is embedded in the substrate with the base top flush with the substrate, and then the trap is then inserted into the base. At subsequent sampling events, the trap is removed and replaced, but the base remains embedded in the streambed. The two-part design allows users to disturb the streambed only once at the onset of deployment, and prevents accidental addition or loss of sediment during deployment or retrieval.

\section{Flume experiments}

We ran two experiments (each with three trials) to test differences between the amount of fine material (sand particles $<0.85 \mathrm{~mm}$ in diameter) accumulated in our sediment sampler versus core samplers (experiment 1), and our sediment sampler versus $\mathrm{W}-\mathrm{V}$ boxes (experiment 2 ). The wooden experimental flume measured $2.4 \mathrm{~m} \times 0.6 \mathrm{~m} \times 0.6 \mathrm{~m}$. For each experiment, the flume was filled to a depth of $12.7 \mathrm{~cm}$ with gravel (Figure 2), and all traps were filled with 12 to 25 
mm diameter gravels. Two water recirculating pumps created flows that averaged $0.51 \mathrm{~m}$ per second (range 0.45 to $0.55 \mathrm{~m}$ per second; 1.47 to 1.80 feet per second).

The flume was visually divided into six blocks. For the first experiment, each section consisted of two rows and each row was assigned a random number. We embedded 18 of our sediment samplers into the gravel of the flume bed, six rows of three samplers each in the lowest numbered row of each block. We added 1.89 liters (two quarts) of fine material at the head of the flume over the top panel covering the water outflow, and the sand dispersed into the water column. Once all sand had been added, the pumps were left on for three additional minutes to allow sufficient flow to transport added material the length of the flume. After three minutes, pumps were turned off, and we removed the sampler traps, sieved rocks from the contents of the sampler traps, and placed the remaining sand in watertight containers for further processing. We collected 12 core samples using a modified core sampler, $10.16 \mathrm{~cm}$ in diameter and $15 \mathrm{~cm}$ in length (constructed out of thin walled 10.16-cm (4-in) PVC pipe). Two core samples were taken in the highest numbered row of each block. The core sampler was placed flush with the bottom of the flume, creating a seal. Rocks were removed and rinsed, and the remaining water and sand was siphoned out of the pipe and placed in a watertight container for further processing. After the sand settled, clear water was removed with a siphon. Samples were dried at $75{ }^{\circ} \mathrm{C}$ for 36 to $48 \mathrm{~h}$ until a constant weight. We weighed the amount of sand from each sample to the nearest $0.0001 \mathrm{~g}$ (Sargent-Welch, SWA 200-DR). After each trial we removed the gravel bed from the flume, and washed out the sand. Clean gravel was returned to the flume, and sediment sampler bases were repositioned in the same place as the previous trial. The three trials took place on 9 July, 18 July, and 2 August 2004. 
For the second experiment, we placed 12 sediment samplers and $12 \mathrm{~W}-\mathrm{V}$ boxes (for detailed methods see Wesche et al. 1989) side by side in the gravel flume bed. Each of he six blocks was assigned four slots. Two sediment samplers and two W-V boxes were randomly assigned a slot in each block. Following methods detailed above, fine material was added to the flume. At the end of each experiment, we removed traps and $\mathrm{W}-\mathrm{V}$ boxes from the flume, rinsed the gravels, and placed the sand from each sampler in a watertight container for further processing. Drying and weighing of material was the same for the sediment sampler and core sampler experiment. To begin subsequent experimental trials, we replaced the traps into sampler bases, and dug the $\mathrm{W}-\mathrm{V}$ boxes back into the gravel bed in the flume. The trials comparing the sediment samplers to W-V boxes were conducted on 14, 18 and 23 August 2004.

A randomized complete block ( $\mathrm{RCB}$ ) design with the block effect for experimental trial was used to compare differences in the mean amount of fine material accumulated within each type of samples during the three trials $(\mathrm{alpha}=0.05)$. If no block effect was detected then data from the three experimental trials were combined to determine differences in the amount of sediment accumulated between gear types within rows. Analysis of variance was used to compare sediment samplers in each row ( $\mathrm{n}=3$ per trial) with the surrounding core samples taken

( $\mathrm{n}=4$ per trial), and to compare sediment samplers and $\mathrm{W}-\mathrm{V}$ boxes from rows 1 through 6 ( $\mathrm{n}=2$ of each gear type per row per trial).

\section{Results}

The RCB design for the three trials comparing the sediment samplers to core samples indicated no significant block effect for experimental trial $(\underline{\mathrm{P}}=0.79)$, and no significant difference between sampling gear type $(\underline{\mathrm{P}}=0.22)$. The trials comparing sediment samplers to 
$\mathrm{W}-\mathrm{V}$ boxes indicated the same results, with no significant block effect for experimental trial $(\underline{\mathrm{P}}=$ $0.92)$ and no difference in the amount of material accumulated by gear type $(\underline{\mathrm{P}}=0.43)$. As expected, deposition decreased with distance from the sediment source for all samplers (our sediment samplers, core samplers, and $\mathrm{W}-\mathrm{V}$ boxes); hence, large variances resulted from differences between rows (Figure 3). The amount of fine material did not differ significantly between our sediment samplers and surrounding core samplers $(\underline{\mathrm{P}}>0.05$; Figure 4$)$. For

combined trials comparing sediment samplers to $\mathrm{W}-\mathrm{V}$ boxes, $\mathrm{W}-\mathrm{V}$ boxes had a significantly greater amount of fine material accumulated in row $2(\underline{\mathrm{P}}=0.007)$, however, in all other rows there were no significant differences $(\underline{P}>0.05$; Figure 4$)$.

\section{Discussion}

Our results indicate that our sediment sampling device can be used in place of core sampling and $\mathrm{W}-\mathrm{V}$ boxes in studies monitoring fine sediment accumulation. Based on experimental flume study of fine sediments less than $0.85 \mathrm{~mm}$ in diameter, the three methods were similar in measurements of sedimentation. Wesche et al. (1989) found that accumulation of fine sediment less than $0.85 \mathrm{~mm}$ did not differ significantly between $\mathrm{W}-\mathrm{V}$ boxes and McNeil core samples $(\underline{\mathrm{P}} \leq 0.05)$ in an experimental flume. Garrett and Bennett (1996) also found intrusion of fine sediment smaller than $0.83 \mathrm{~mm}$ to be similar in spawning gravel and $\mathrm{W}-\mathrm{V}$ boxes in a study on the North Fork of the Payette River, near McCall, Idaho.

The sediment sampling device was designed for long term monitoring of sites impacted by highway construction. We plan to take repeated measures of sediment accumulation at paired sites upstream and downstream from construction and ultimately correlate these with changes in the benthic macroinvertebrate community. Our design allows users to monitor temporal changes 
in sediment, where the streambed is disturbed only once during initial deployment, limiting impacts on the study. Core sampling and the W-V box methods disturb the streambed when retrieving or replacing samplers.

The sampling design does include installation of a rigid structure (without openings "at depth" or within the portion of the trap embedded in the substrate) into the stream bed. This does not appear to change the effectiveness of the sampler. We chose not to have openings "at depth" because during initial testing of various designs we visually noticed sediment infiltrating into the trap during deployment. Whitlock-Vibert boxes have openings at depth, and we visually noticed sediment being lost through these openings as the boxes were pulled from the substrate and through the water column in the experimental flume. Garret and Bennet (1996) found no significant difference in the amount of fines $(<0.83 \mathrm{~mm})$ collected between $\mathrm{W}-\mathrm{V}$ boxes wrapped in plastic screening and surrounding gravels, or between unwrapped $\mathrm{W}-\mathrm{V}$ boxes and surrounding gravels. Unwrapped boxes accumulated more fines than wrapped boxes, and the authors attributed this to a sand seal (sand particles bridging the openings of the mesh and preventing infiltration of fines). The open top design of our sampler prevents formation of a sand seal.

Our sediment sampling device was designed specifically to monitor impacts from highway construction on small streams in the Appalachian Region. It is useful for collection of sediment data in long-term studies, and to quantify sediment for time periods before, during, and after construction (or other anthropogenic contributors of stream sedimentation). Our design, with a stationary base and removable trap, minimizes labor necessary to collect a sediment sample every six weeks. In addition to monitoring sediment intrusion, long-term data from our sediment samplers will prove useful as covariates in models of sediment accumulation and changes in aquatic communities. 
Sediment trapping methods are useful in determining the amount of fine material accumulated over a time period. However, they do not characterize the current substrate, or document changes in coarser substrate over time. Repeated measures using core samples and the shovel method would be more beneficial for this use. These methods have been used in studies assessing the effects of substrate composition in redds on the survival and emergence of fishes, particularly salmonids (Grost 1991, Platts et al. 1989).

Alterations to the sediment sampler design can be made to adjust for local conditions. We were using the sampler in small first and second order streams in the Appalachians. Conditions in these streams did not require us to anchor the devices. Anchors could be added if samplers were used in streams with higher flows. The open top design does allow infiltration of multiple sizes of material. If the user was interested in a particular sediment size, screening could be placed over the top of the sampler. Screening may also prevent scouring of the samplers during high flow events. In our study area, stream beds have limited interstitial spaces in the substrate. Sediment deposition most often results from fines being transported across the surface of the substrate. Therefore, we do not believe that our sampler underestimates sediment infiltration by not having openings "at depth". The closed design also prevents addition of material to the sampler during deployment, and loss of material during retrieval.

\section{Acknowledgements}

We thank Dr. Kyle Hartman, West Virginia University Department of Wildlife and Fisheries for use of his mechanical screen shaker and scales. The West Virginia Division of Highways provided partial support for this research. Reference to trade names does not imply 
government endorsement of commercial products. The sediment sampler has U.S. patent number 6823749 (November 30, 2004).

\section{Literature Cited}

Berkman, H.E. and C.F. Rabeni. 1987. Effects of siltation on stream fish communities.

Environmental Biology of Fishes. 18:285-294.

Beschta, R.L. 1978. Long-term patterns of sediment production following road construction and logging in the Oregon coast range. Water Resources Research 14:1011-1016.

Brown, A.V., M.M. Lytle, and K.B. Brown. 1998. Impacts of gravel mining on gravel bed streams. Transactions of the American Fisheries Society 127:979-994.

Cline, L.D., R.A. Short, and J.V. Ward. 1982. The influence of highway construction on the macroinvertebrate and epilithic algae of a high mountain stream. Hydrobiologia 96:149159.

Corn, P.S. and R.B. Bury. 1989. Logging in western Oregon: Responses of headwater habitats and stream amphibians. Forest Ecology and Management 29:39-57.

Crawford, J.K. and D.R. Lenat. 1989. Effects of land use on the water quality and biota of three streams in the Piedmont province of North Carolina. U. S. Geological Survey. Water Resources Investigation Report 89-4007. Raleigh, North Ccarolina. 67 pp.

Dennehy, K.F., D.W. Litke, C.M. Tate, S.L. Qui, P.B. McMahon, B.W. Bruce, R.A. Kimbrough, and J.S. Heiny. 1998. Water Quality in the South Platte River Basin, Colorado, Nebraska, and Wyoming, 1992-1995. U. S. Geological Survey Circular 1167. 
Eaglin, G.S. and W.A. Hubert. 1993. Effects of logging and roads on substrate and trout in streams of the Medicine Bow National Forest, Wyoming. North American Journal of Fisheries Management 13:844-846.

Garrett, J.W. and D.H. Bennett. 1996. Evaluation of fine sediment intrusion into WhitlockVibert boxes. North American Journal of Fisheries Management 16:448-452.

Grost, R.T., W.A. Hubert, and T.A. Wesche. 1991. Field comparison of three devices used to sample substrate in small streams. North American Journal of Fisheries Management $11: 347-351$

Hames, D.S., B. Conrad, A. Plues, and D. Smith. 1996. Field comparison of the McNeil sampler with three shovel-based methods used to sample spawning substrate composition in small streams. Northwest Indian Fisheries Commission, Report TFW-AM-9-96-005.

Hedrick, L.B., S.A. Welsh, and J.D. Hedrick. 2005. A new sampler design for measuring sedimentation in streams. North American Journal of Fisheries Management 25:238-244.

Henley, W.F., M.A. Patterson, R.J. Neves, and A.D. Lemley. 2000. Effects of sedimentation and turbidity on lotic food webs: A concise review for natural resource managers. Reviews in Fisheries Science 8: 125-139.

Jones, E.B.D. III, G.S. Helfman, J.O. Harper, and P.V. Bolstad. 1999. Effects of riparian forest removal on fish assemblages in southern Appalachia streams. Conservation Biology $13: 1454-1465$.

Judy, R.D., Jr., P.N. Seeley, T.M. Murray, S.C. Svirsky, M.R. Whitworth, and L.S. Ischinger. 1984. 1982 National Fisheries Survey, volume I. Technical report: initial findings. U. S. Fish and Wildlife Service, FWS-OBS-84/06, Washington, D.C. 
King, D.L. and R.C. Ball. 1965. The influence of highway construction on a stream. Michigan State University, Agriculture Experiment Station, East Lansing. Research Report Number 19. $4 \mathrm{pp}$.

Lachance, S. and M. Dube. 2004. A new tool for measuring sediment accumulation with minimal loss of fines. North American Journal of Fisheries Management 24: 303-310.

McNeil, W.F. and W.H. Ahnell. 1964. Success of pink salmon spawning relative to size of spawning bed materials. U. S. Fish and Wildlife Service Special Scientific ReportFisheries Number 469. Washington, D.C.

Platts, W.S., R.J. Torquemada, M.L. McHenry, and C.K. Graham. 1989. Changes in salmon spawning and rearing habitat from increased delivery of fine sediment to the South Fork Salmon River, Idaho. Transactions of the American Fisheries Society 118:274-283.

Rabeni, C.F. and M.A. Smale. 1995. Effects of siltation on stream fish and the potential mitigating role of the buffering zone. Hydrobiologia 303:211-219.

Richter, B.D., D.P. Braun. M.A. Mendelson, and L.L. Master. 1997. Threats to imperiled freshwater fauna. Conservation Biology 11: 1081-1093.

Scrivener, J.C., and M.J. Brownlee. 1989. Effects of forest harvesting on spawning gravel and incubation survival of chum (Oncorhynchus keta) and coho salmon (O. kisutch) in Carnation Creek, British Columbia. Canadian Journal of Aquatic Sciences 46:681-696.

USEPA (United States Environmental Protection Agency). 1990. National water quality inventory: 1988 report to Congress. EPA Report 440490003, Washington, D.C.

Wasler, C.A., and H.L. Bart, Jr. 1999. Influence of agriculture in in-stream habitat and fish community structure in Piedmont watersheds of the Chattahoochee River System. Ecology of Freshwater Fish 8 (4): 237-246. 
Wellman, J.C., D.L. Combs, and S.B. Cook. 2000. Long-term impacts of bridge and culvert construction or replacement on fish communities and sediment characteristics of streams. Journal of Freshwater Ecology 15:317-328.

Welsh, H.H. and L.M. Ollivier. 1998. Stream amphibians as indicators of ecosystem stress: A case study from California's redwoods. Ecological Applications 8:1118-1132.

Wesche, T.A., D.W. Reiser, V.R. Hasfurther, W.A. Hubert, and Q.D. Skinner. 1989. New technique for measuring fine sediment in streams. North American Journal of Fisheries Management 9:234-238. 


\section{Figure Captions}

Figure 1. Original sediment sampler design consisting of a stationary base and removable trap (for details on manufacturing see Hedrick et al. 2005).

Figure 2. Wooden flume designed for sediment sampler experiments. Water source is located below the panel. Sediment was added to the panel and water was allowed to wash the sediment into the flume.

Figure 3. Mean amount of (A) sand accumulated in sediment samplers $(n=18)$ and removed with core samples $(n=12)$ and $(B)$ sand accumulated in sediment samplers $(n=12)$ and $W-V$ boxes $(n=12)$ from three trials in an experimental flume. Error bars indicate $95 \%$ confidence intervals.

Figure 4. Mean amount of sand accumulated in (A) sediment samplers $(n=9)$ per row and surrounding core samples $(n=12)$ and $(B)$ sediment samplers $(n=6)$ and $W-V$ boxes $(n=6)$ per row from three combined trials in an experimental flume. Error bars indicate $95 \%$ confidence intervals. 
Figure 1

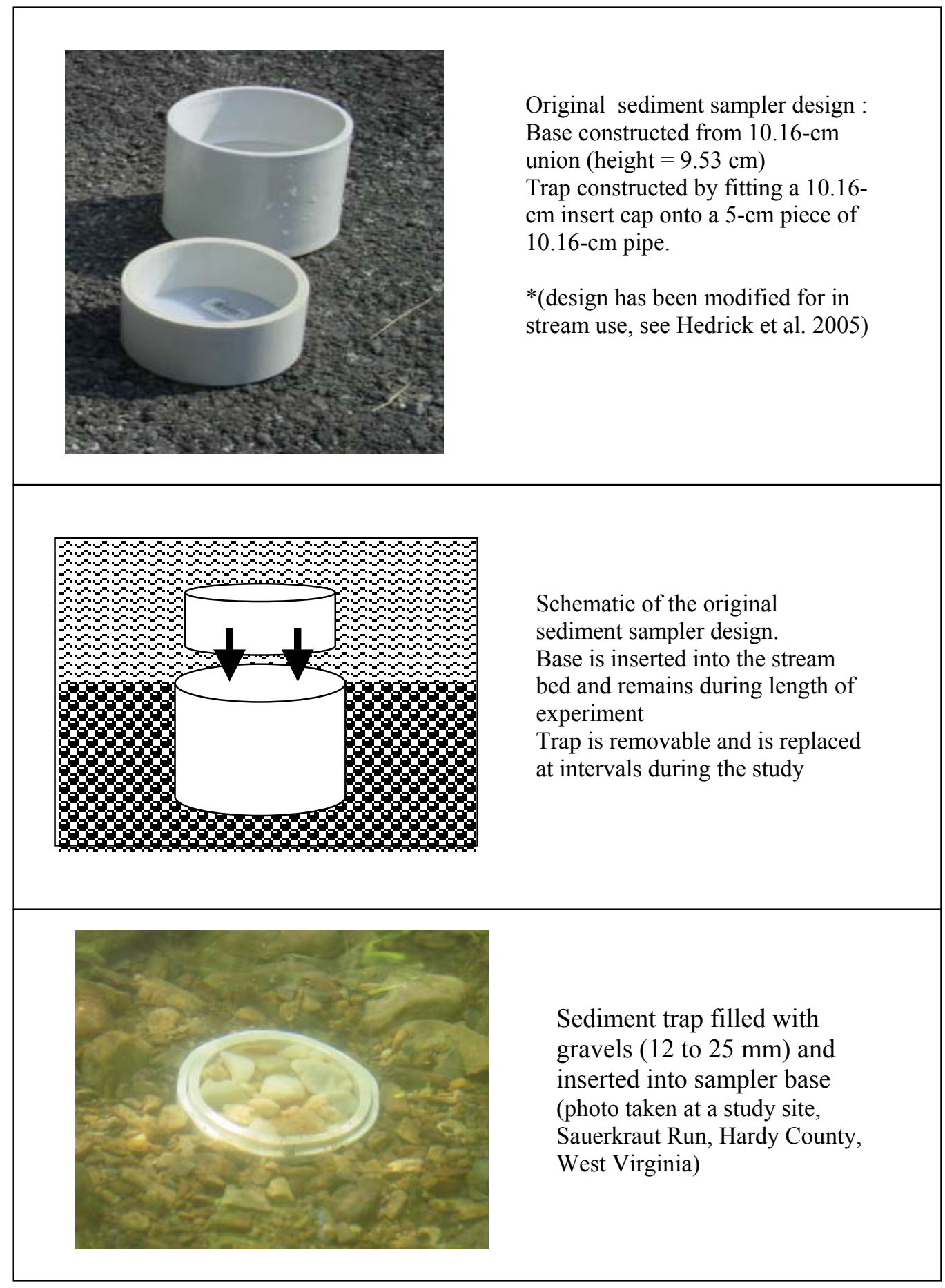


Figure 2

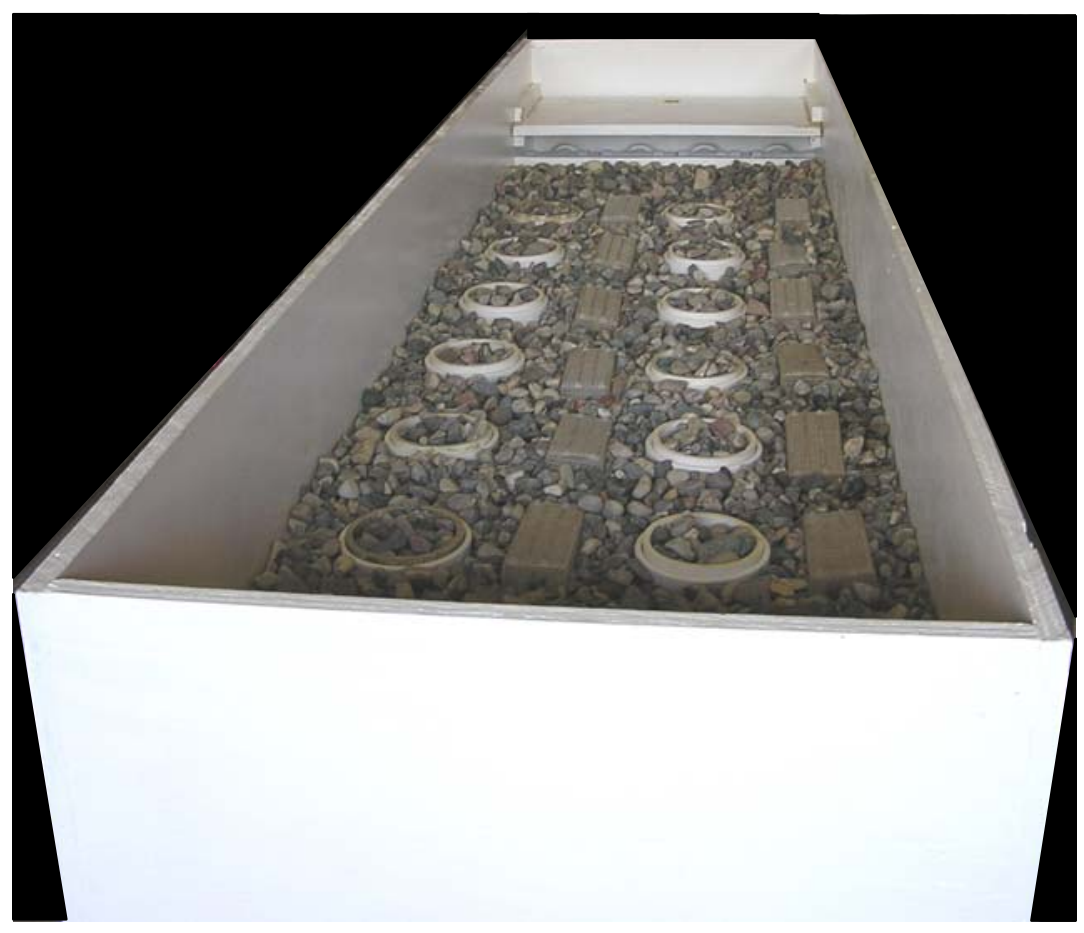


Figure 3

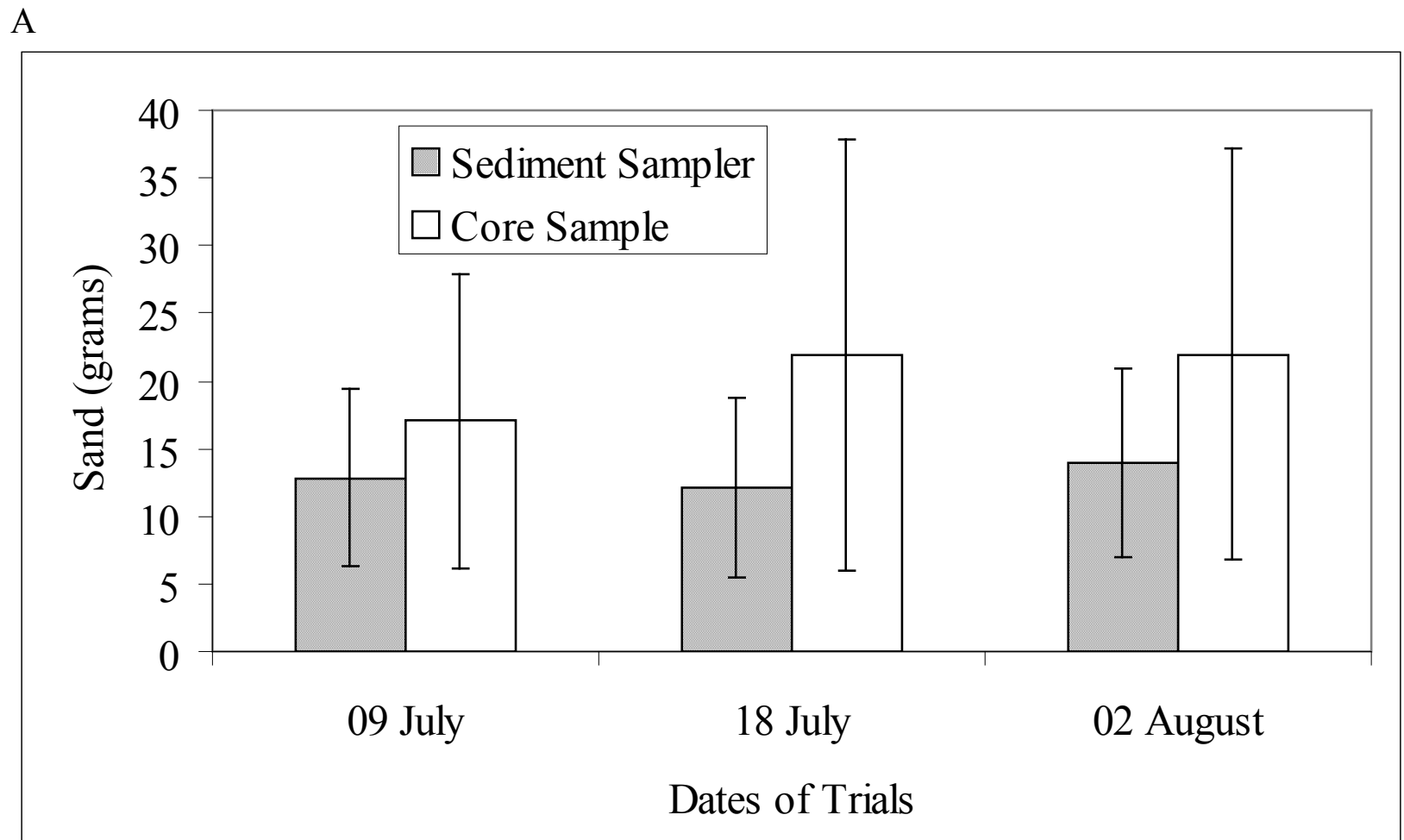

B

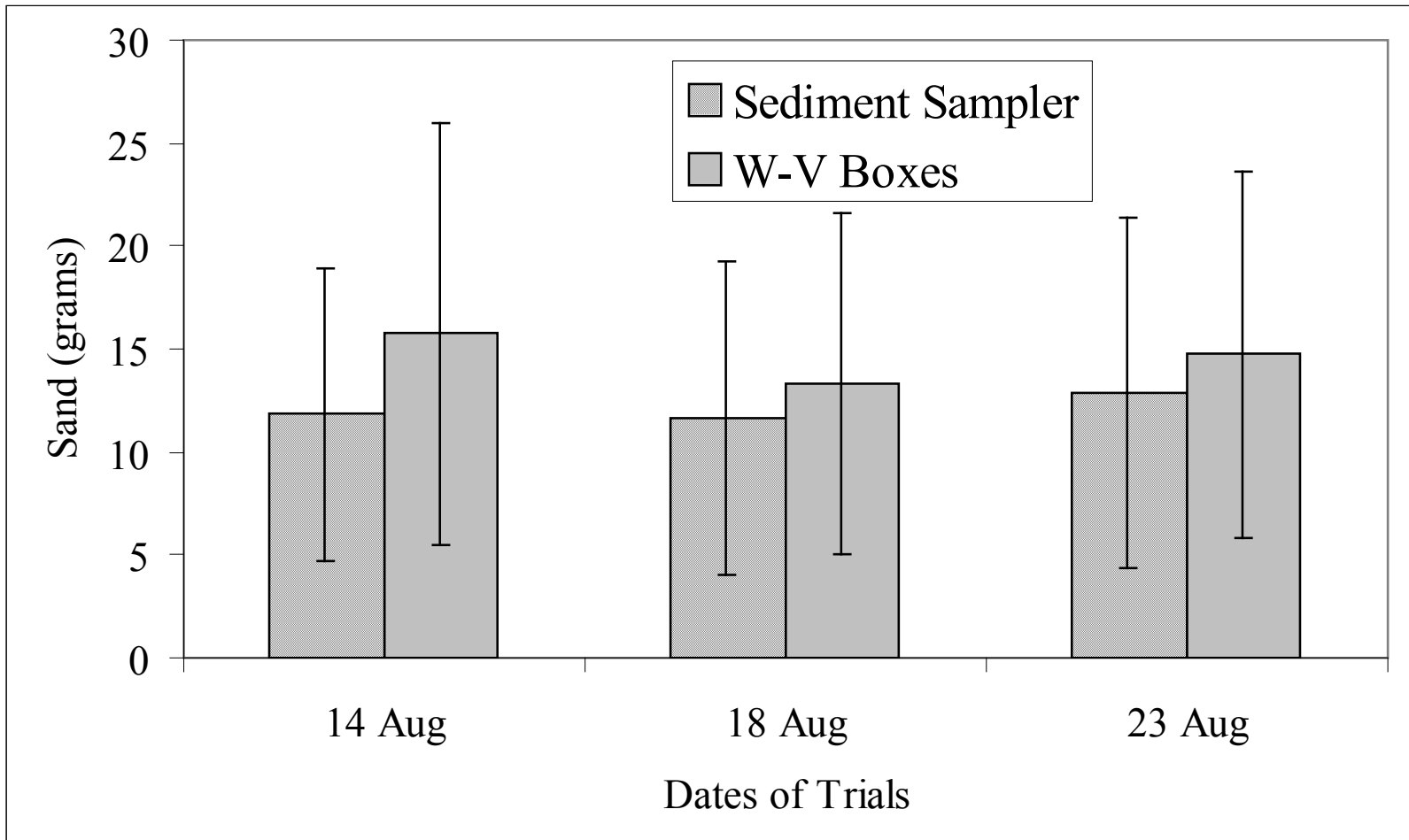


Figure 4

A

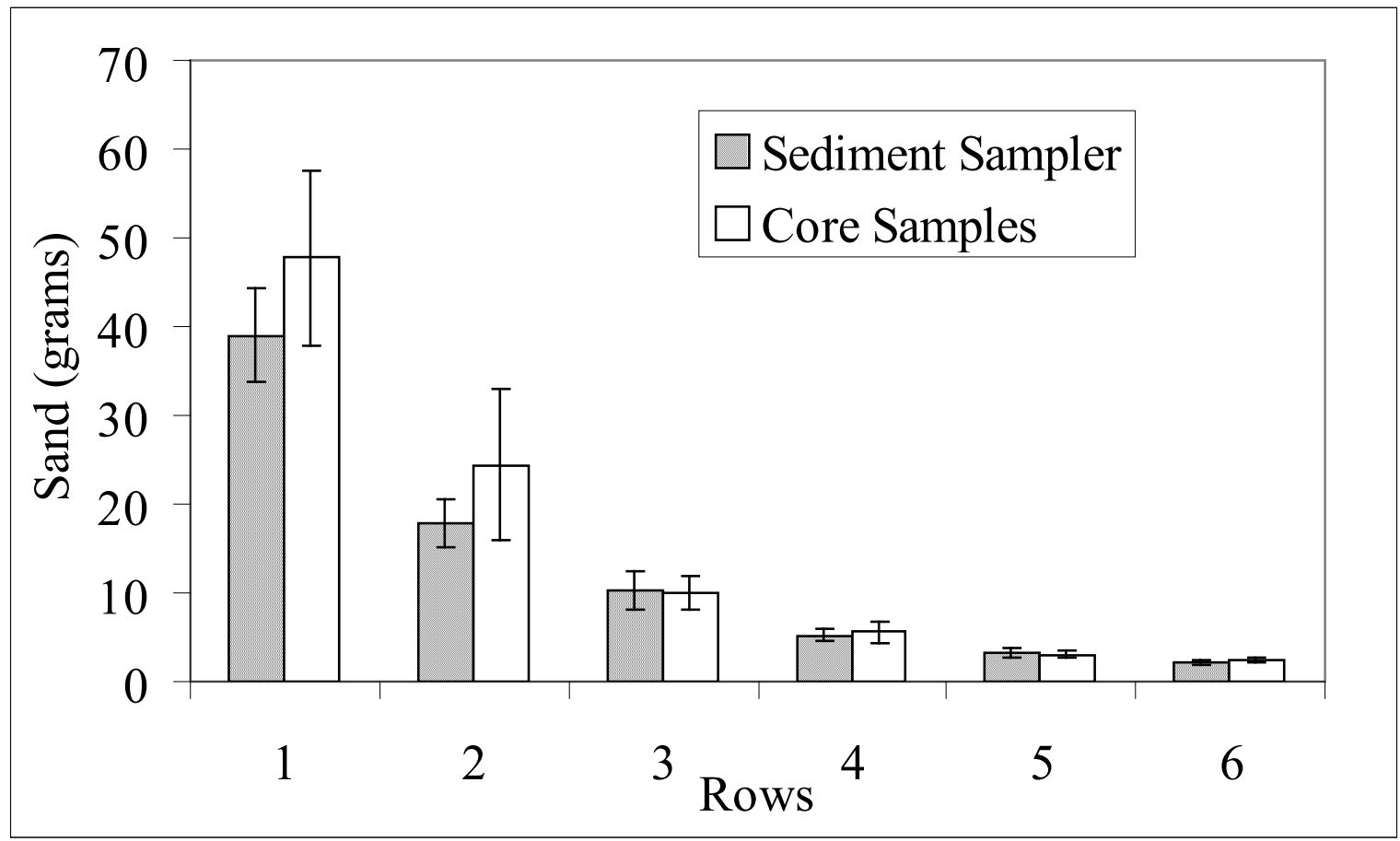

B

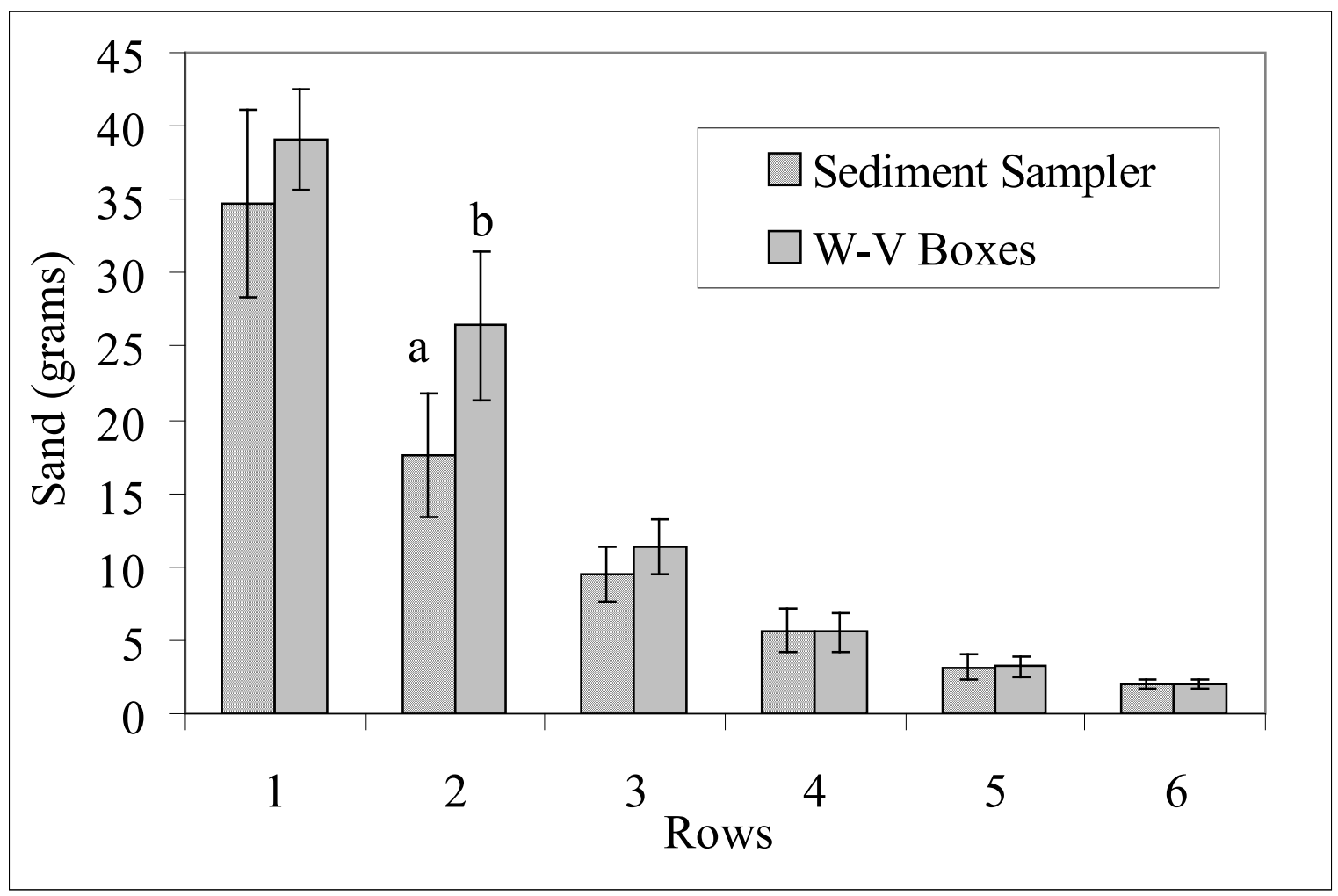




\title{
Chapter 4 - Effects of Highway Construction on Sediment and Benthic
}

\author{
Macroinvertebrates in Two Tributaries of the Lost River, West Virginia ${ }^{1}$
}

${ }^{1}$ This chapter written in the style of the Journal of Freshwater Ecology and is published as -

Hedrick, L.B., S. A Welsh, and J. T. Anderson. 2007. Effects of highway construction on sediment and benthic macroinvertebrates in two tributaries of the Lost River, West Virginia. Journal of Freshwater Ecology 22:561-569. 


\begin{abstract}
During a three-year study of two tributaries being crossed by a four-lane highway under construction in the eastern panhandle of West Virginia, we found little difference in the amount of fine sediment collected at upstream and downstream sites. The downstream site on one tributary collected significantly greater amounts of sediment in 2003, prior to installation of sediment fencing. Despite several episodic flow events that caused changes in the streambed, benthic macroinvertebrate metrics did not differ significantly annually or seasonally between sites or between streams. On-site controls effectively checked new sedimentation, and benthic macroinvertebrates were not significantly impacted.
\end{abstract}

\title{
Introduction
}

The Appalachian Development Highway System is a four-lane highway that, upon completion, will stretch from New York to Mississippi. Construction began in May 2000 on a $161 \mathrm{~km}$ long stretch of this highway through four counties in northeastern West Virginia. In West Virginia alone the highway will cross approximately 25 streams in 11 watersheds.

Although many studies have been conducted on the effects of road construction on aquatic communities (King and Ball 1965, Barton 1977, Beschta 1978, Chisholm and Downs 1978, Cline et al. 1982, Eaglin and Hubert 1993, King et al. 2000, Wellman et al. 2000), few have been related to highways built in mountainous areas. Most studies involved assessing effects of sedimentation or siltation. However, in a review of papers on the subject, Henley et al. (2000) pointed out that impacts often seem inconsistent. Therefore, our objectives were to compare sediment accumulated at sites upstream and downstream of the highway construction in 
the mountainous region of West Virginia, and compare the benthic macroinvertebrate communities upstream and downstream of construction.

The specific study sites were located on two first-order tributaries of the Lost River in Hardy County, West Virginia — Sauerkraut Run and an unnamed tributary of the Lost River, hereafter referred to a "Tributary Stream". Tributary Stream ran through a culvert beneath a valley fill that was used to create a suitable place for highway construction. The stream passed through the culvert, under the highway, and into a sediment pond. The upstream survey site on Tributary Stream was located approximately $400 \mathrm{~m}$ from the construction site, and the downstream sampling site was located $100 \mathrm{~m}$ from the construction area. A highway overpass bridge was constructed over Sauerkraut Run, and a temporary culvert was placed in the stream to create an earthen bridge for construction equipment use. The upstream survey site on Sauerkraut Run was located approximately $250 \mathrm{~m}$ from the construction site, and the downstream sampling site was located $70 \mathrm{~m}$ from the construction area. 


\section{Materials and Methods}

\section{Sediment sampling}

We began monitoring the two streams in July 2002. We collected sediment samples using the method described by Hedrick et al. (2005) with six sediment samplers at each upstream and downstream site. Every six weeks from July through December 2002, May through December 2003, and April through December 2004, we removed and replaced sediment traps. In the laboratory, sediments were allowed to settle, and clear water was removed with a siphon. Samples were dried at $75{ }^{\circ} \mathrm{C}$ to a constant weight. Each sample was sieved into five size classes $($ class $1=>4.70 \mathrm{~mm}$; class $2=>2.28$ to $4.70 \mathrm{~mm}$; class $3=>1.40$ to $2.28 \mathrm{~mm}$; class $4=0.85$ to $1.40 \mathrm{~mm}$; and class $5=<0.85 \mathrm{~mm}$ ), which were weighed to the nearest $0.1 \mathrm{mg}$. "Fines" were defined as sediment $<2.28 \mathrm{~mm}$ in diameter (Kaufmann et al. 1999).

We analyzed the data using a mixed-model methodology for repeated measures and a meta-analysis approach. The mixed-model methodology is a two-step process. Using the SAS PROC MIXED procedure and second order adjustment of Akaike's information criterion (Littell et al. 1996), we selected the appropriate covariance structure for data of each size class. Site and time period were included in the mixed model as fixed effects, and repeated measures were taken on the experimental unit (i.e., sample nested within site). Then the least-square mean of sediment in each size class from each site (upstream and downstream) and six-week period was estimated, and analysis of site and time interactions and trends across time was conducted. The SLICE option was used to test the site effect at each time period (Littell et al. 2002). We modeled the average flow during a six-week period and the maximum flow during a six-week period as covariates. Flow data was obtained from a USGS gauge located on a neighboring tributary of the Lost River. 
The meta-analysis on the sediment data collected from Sauerkraut Run and Tributary Stream was conducted using SAS PROC MEANS (Arthur et al. 2001). The first step in the analysis was to convert the results from the multiple observations into a common metric, for which we selected the effect size, $d$. The $d$ statistic was calculated as the difference between the means of the downstream and upstream sites divided by the pooled within-site standard deviation (Hunter and Schmidt 1990). The $d$ statistic provides a measure of the strength of a treatment or independent variable (i.e., different sampling locations). A positive $d$ value indicates that the downstream site had a greater effect on the dependant variable than the upstream site. A negative $d$ value indicates the reverse, and zero indicates no difference. We removed the variance attributed to sampling error from the total variance across $d$ and used that value to calculate the corrected standard deviation. A chi square test for homogeneity was used to test for the effects of moderator variables.

\section{Benthic macroinvertebrates}

We collected benthic macroinvertebrate samples every six weeks using a modified version of the single habitat protocol described by Barbour et al. (1999). A $500 \mu$ net with a $50 \mathrm{x}$ $30 \mathrm{~cm}$ sampling frame was placed in the streambed to collect invertebrates as they were dislodged from a hand-disturbed $0.25 \mathrm{~m}^{2}$ of riffle area immediately upstream of the net. Large rocks in this area had their surfaces rubbed into the water flowing into the net, and the substrate was then disturbed to a maximum depth of four centimeters. We composited four such samples to obtain a $1 \mathrm{~m}^{2}$ sample for each site. In the laboratory, samples were sub-sampled symmetrically, and macroinvertebrates were enumerated and identified according to Merritt and Cummins (1996) and Wiggins (1996). 
We calculated the West Virginia Stream Condition Index (WV-SCI), a multi-metric index developed specifically for West Virginia wadeable streams (U. S. EPA 2000). The WVSCI includes six normalized metrics using family level data — EPT (Ephemeroptera, Plecoptera, Trichoptera) taxa, total taxa, \% EPT, \% Chironomidae, $\%$ of the top two dominant taxa, and HBI (Hilsenhoff Family Biotic Index). The normalized metric scores range from 0 to 100 and are categorized as $>78-100=$ very good; $>68-78=$ good; $>45-68=$ fair; $>22-45=$ poor; and 0 $-22=$ very poor.

Benthic data were combined for each site by season, and analysis of variance (ANOVA) was used to determine significant differences $(\alpha=0.05)$ in WV-SCI scores between paired sites. The Shapiro-Wilks test for normality was used on data sets from sites to determine univariate normality. Linear regression was used to compare WV-SCI scores to the mean percent of sediment collected in each size class. A meta-analysis was also conducted on the benthic macroinvertebrate data.

\section{Results and Discussion}

\section{Sauerkraut Run sediment samples}

Appropriate covariance structure was autoregressive, and repeated measures analyses indicated significant $(p<0.05)$ site $\mathrm{x}$ time interaction for sediment in all size classes except size class 2. The average total amount of sediment collected upstream ranged from 39.4 to 214.7 grams; downstream ranged from 116.4 to 340.2 grams (Fig. 1). There was a significant $(p<$ 0.05) linear effect for sediment collected at the downstream site; however, trends did not apply to the upstream site, and the percentage of sediment collected per size class was consistent over time. In general, more sediment was collected at the downstream site, but there was little 
difference between the two sites in terms of percent composition of that sediment. Sediment fencing downstream was not constructed until October 2002 and resulted in significantly greater amounts of sediment collected downstream prior to this date.

Only eleven of the surveys of Sauerkraut Run were used in the meta-analysis because no samplers were recovered from the downstream site in December 2003. There was a large difference $(d=0.81)$ in the total amount of sediment collected upstream and downstream, with the downstream site collecting more sediment (in grams) overall (Table 1). There was a moderate difference $(0.20<d<0.50)$ in the percent of sediment collected in size classes 1,5 , and fines between the two sites. The chi-square values for percent sediment in size classes 3 and 4 were significant, indicating that a moderator variable could be present. Subsequently, metaanalysis with the inclusion of year as a moderator variable demonstrated that for both of these size classes the upstream site had more sediment collected in 2002 and 2003 than did the downstream site. However, in 2004, there was more sediment in these size classes at the downstream site.

Although we did not find average flow and maximum flow over a six-week period to be covariates, episodic flow events did affect the streambed and sediment collected. High flows during November 2002 created a scouring event downstream of the construction area, changing the morphology of the streambed at the downstream site. The total amount of sediment and percentages in each size class were very similar between sites the period of December 2002, and this was most likely due to movement and flushing of sediment by the higher flow in November. High spring flows in 2004 caused aggregation and destabilization of a gravel levee upstream of the downstream sampling site. Continual scouring of this stream reach and transport of the 
sediment downstream caused increases in the percent of sediment in classes 3 and 4 throughout the 2004 sampling season.

\section{Tributary Stream sediment samples}

Appropriate covariance structure was autoregressive, and repeated measures analyses indicated significant $(p<0.05)$ site $\mathrm{x}$ time interaction for sediment in all size classes except size class 1 . The average total amount of sediment collected upstream ranged from 44.0 to 228.1 grams; downstream ranged from 28.1 to 246.8 grams (Fig. 1). There were no significant linear or quadratic effects at either site. The downstream site collected a greater amount of total sediment and a higher percentage of sediment in class 1 . Eleven of the surveys of the Tributary Stream were used in the meta-analysis because no samplers were recovered from the upstream site in February 2003 or from the downstream site in December 2003 (Table 1). There was a moderate difference $(0.20<d<0.50)$ between the upstream and downstream sites in the percentage of sediment in size classes 1 and 5 and the total amount collected, with the downstream site having greater values. There was a large difference $(d>0.80)$ in the percent collected in size classes 3 and 4 , and a small difference $(d<0.20)$ in the percent collected for fines. The upstream site collected more in all of these size classes. The chi-square values were not significant for any of the size classes; thus there were no moderator variables involved.

Several episodic events contributed to the significant differences between upstream and downstream sites. When a severe rain event occurred in August 2003, freshly scraped road material from unrelated roadwork on an adjacent state road buried the samplers at the downstream site. Thus samplers were not collected in August 2003. Low summer flows affected the 2004 samples. The upstream reach of Tributary Stream was an intermittent channel, 
and lack of flow and flushing of sediment may have resulted in the higher percentages of size classes 3 and 4 upstream during the 2004 sampling season.

\section{Benthic Macroinvertebrates}

A total of 12 benthic macroinvertebrate samples was collected from sites on Sauerkraut Run, and 14 samples were collected from sites on Tributary Stream. Analyses were conducted on both seasonal and annual sample means. Samples were designated as spring and fall for seasonal analyses. Because the summer of 2003 was a period when the upstream site of Tributary Stream was dry, summer comparison with the downstream site was not possible.

The WV-SCI index was not significantly different $(\mathrm{p}<0.5)$ annually or seasonally between upstream and downstream sites on Sauerkraut Run or Tributary Stream. Samples collected downstream on Sauerkraut Run and downstream and upstream on Tributary Stream ranged from fair ( $>45$ to 68 ) to very good ( $>78$ to 100 ). Samples collected upstream on Sauerkraut Run ranged from good (> 68 to 78 ) to very good (Table 2). There were no seasonal differences between streams. Annually there was only a difference between upstream sites during 2003, but the 2003 data included summer samples and the upstream site on Tributary Stream had very low flow and was dry during several sampling events.

Benthic macroinvertebrate WV-SCI was positively related to increasing percentages of class 5 sediment $\left(r^{2}=0.635\right)$ and fines $\left(r^{2}=0.505\right)$ at the downstream sites. The WV-SCI score was negatively related to the total amount of sediment collected $\left(r^{2}=0.448\right)$.

Four seasons of benthic macroinvertebrate data were used in the meta-analysis - fall 2002, spring 2003, fall 2003, and spring 2004. There was a moderate difference $(0.20<d<0.50)$ 
in WV-SCI scores between upstream and downstream sites, with upstream having higher scores (Table 2). Upstream sites had more sensitive taxa.

In general, highway construction had little impact on the benthic macroinvertebrate populations in Sauerkraut Run and Tributary Stream. Annually and seasonally, there was little difference in the WV-SCI metric scores between upstream and downstream sites. Because only one composite benthic macroinvertebrate sample was collected at each site on each date, there was no variance by date. However, individual samples provided some insight into relations between benthic macroinvertebrate metrics and sediment deposition.

The WV-SCI scores from samples collected downstream in Sauerkraut Run in July and October 2002 indicated benthic macroinvertebrate communities in "fair" biotic condition. These samples were collected prior to sediment fencing at the construction site and during a time period when sediment percentages in class 1 and total sediment were significantly greater at the downstream site. Sauerkraut Run was frozen over in March 2003. The low WV- SCI scores in April 2003 were most likely due to scouring of the streambed during a high spring runoff flow event following ice melt. The other downstream WV-SCI score below the "good" category was in December 2003 when there was an episode of high flow due to unusually heavy rainfall. Approximately two feet of bed material were removed, and the wetted width increased from 1.98 $\mathrm{m}$ to $4.27 \mathrm{~m}$.

The upstream site on Tributary Stream was intermittent, and there were four sampling events where benthic macroinvertebrate samples could not be collected due to extremely low flow. A poor WV-SCI value in February 2002 was due to limited flow and ice on the stream. Fair scores in July and September 2003 were related to aggradation of the streambed when gravel and sediment from a nearby existing state road washed into the stream. 
During the three-year study, benthic macroinvertebrate communities remained in good biotic condition. When an event occurred that affected the communities, recovery was evident within a short period of time. Our findings were consistent with other studies concerning the impacts of road construction and sediment on benthic macroinvertebrates. Cline et al. (1982) evaluated the response of a high elevation Rocky Mountain stream to highway construction over a three-year period. They found that suspended solids and sediment increased at the impacted study sites during construction, but assessment values at impacted sites approached reference site levels within two weeks after construction ended. Although the density of benthic macroinvertebrates at impacted sites was lower than reference sites during and immediately following construction, within one year after construction ended, values were comparable to reference sites.

Chisholm and Downs (1978) monitored benthic macroinvertebrates at four sites on Turtle Creek, a stream impacted by the construction of another stretch of highway in West Virginia. Diversity and abundance decreased during the construction of the highway; however, repopulation and diversification of disturbed and newly created reaches of Turtle Creek occurred quickly. Within about one year the disturbed stream had a benthic macroinvertebrate community similar to that in the control stream.

We found that complete removal of the streambed such as the degradation in December 2003 did not have a long term effect on the benthic macroinvertebrate community. Barton (1977) found similar results in a study concerning highway construction across Halon Creek, a small stream in Ontario. At one monitoring site the streambed was completely removed during culvert construction. After completion, the riffles were replaced, and within a year species composition and abundance were similar to pre-construction. 
We did not find a strong linear relationship between benthic macroinvertebrate metrics and percentages of sediment. We hypothesized that an increase in fine sediment would cause a decline in benthic macroinvertebrate density and sensitive taxa. However, there was actually a positive relationship between finer classes of sediment and the WV-SCI score (Table 3). We did find a negative relationship between the percentage of sediment in size class 1 and the total amount of sediment and the WV-SCI score. These results were contrary to other studies that found a change in community composition and a decrease in sensitive taxa (Barton 1977, Kaller and Hartman 2004). In Halon Creek, sediment deposition increased following culvert construction during a stream rechannelization phase, the majority of the sediment influx was related to sandy material used for backfill around the construction site, and there was a decrease of ephemeropterans and an increase in dipterans (Barton 1977). Kaller and Hartman (2004) found a decrease in EPT taxa richness in Appalachian streams where fine substrate particles $(<0.25 \mathrm{~mm})$ exceeded $0.8-0.9 \%$ of riffle substrate composition. However, our study did not evaluate classes of sediment any smaller than $<0.85 \mathrm{~mm}$. Further analysis of smaller classes may have indicated different relationships between the benthic macroinvertebrate community and fine sediment.

Highway construction impacts were lessened by the use of construction erosion controls at the sites we monitored. Although greater total amounts of sediment were documented at the downstream reaches, these were not harmful to the benthic macroinvertebrate communities in the long term. Successful recolonization and recruitment of the benthic macroinvertebrates from unaffected stream reaches were most likely the reasons for the continued high WV-SCI scores at the downstream sites. Chisholm and Downs (1978) attributed the successful recovery of Turtle 
Creek to tributary inflow and benthic macroinvertebrate drift from unaltered reaches as well as good management practices such as bank recontouring and reseeding.

\section{Acknowledgements}

We thank Kyle Hartman, West Virginia University Division of Forestry and Natural Resources for use of his mechanical screen shaker and scales. The West Virginia Division of Highways provided partial support for this research. Jim Hedrick, Will Ravenscroft, and Seth Lemly provided invaluable help in field collections and laboratory work. Reference to trade names does not imply government endorsement of commercial products.

\section{Literature Cited}

Arthur, W., Jr., W. Bennett Jr., and A. I. Huffcutt. 2001. Conducting meta-analysis using SAS. Lawernce Erlbaum Associates, Inc., Malwah, New Jersey, USA.

Barbour, M.T., J. Gerritsen, B.D. Snyder, and J.B. Stribling. 1999. Rapid bioassessment protocols for use in streams and wadeable rivers: periphyton, benthic macroinvertebrates and fish, Second Edition. EPA 841-B-99-002. U.S. Environmental Protection Agency, Office of Water, Washington, D.C.

Barton, B. A. 1977. Short-term effects of highway construction on the limnology of a small stream in southern Ontario. Freshwater Biology 7: 99-108

Beschta, R. L. 1978. Long-term patterns of sediment production following road construction and logging in the Oregon coast range. Water Resources Research 14:1011-1016. 
Chisholm, J. L. and S. C. Downs. 1978. Stress and recovery of aquatic organisms as related to highway construction along Turtle Creek, Boone County, West Virginia. U.S. Geological Survey Water Supply Paper 2055, Washington, DC.

Cline, L. D., R. A. Short, and J. V. Ward. 1982. The influence of highway construction on the macroinvertebrate and epilithic algae of a high mountain stream. Hydrobiologia 96:149159.

Eaglin, G. S. and W. A. Hubert. 1993. Effects of logging and roads on substrate and trout in streams of the Medicine Bow National Forest, Wyoming. North American Journal of Fisheries Management 13:844-846.

Edmunds, Jr., G. F., S. L. Jensen, and L. Berner. 1976. The mayflies of North and Central America. North Central Publishing Company, St. Paul, Minnesota, USA.

Hedrick, L.B., S.A. Welsh, and J.D. Hedrick. 2005. A new sampler design for measuring sedimentation in streams. North American Journal of Fisheries Management 25: 238244.

Henley, W. F., M. A. Patterson, R. J. Neves, and A. D. Lemley. 2000. Effects of sedimentation and turbidity on lotic food webs: A concise review for natural resource managers. Reviews in Fisheries Science 8: 125-139.

Hunter, J. E. and F. L. Schmidt. 1990. Methods of meta-analysis: correcting error and bias in research findings. Sage, Newbury Park, California, USA.

Kaller, M.D. and K. J. Hartman. 2004. Evidence of a threshold level of fine sediment accumulation for altering benthic macroinvertebrate communities. Hydrobiologia 518: 95-104. 
Kaufmann, P. R., P. Levine, E. G. Robinson, C. Seeliger, and D. V. Peck. 1999. Quantifying physical habitat in wadeable streams. EPA/620/R-99/003. U. S. Environmental Protection Agency, Washington, D. C.

King, D. L. and R. C. Ball. 1965. The influence of highway construction on a stream. Michigan State University, Agriculture Experiment Station, East Lansing. Research Report Number 19. 4 pp.

King, R. R., K. T. Nunnery, and C. J. Richardson. 2000. Macroinvertebrate assemblage response to highway crossings in a forested wetlands: implications for biological assessment. 2000. Wetlands Ecology and Management 8:243-256.

Littell, R. C., G. A. Miliken, W. W. Stroup, and R. D. Wolfinger. 1996. SAS system for mixed models. SAS Institute, Inc. Cary, North Carolina.

Littell, R. C., W. W. Stroup, and R. J. Freund. 2002. SAS for linear models, Fourth Edition. SAS Institute, Inc. Cary, North Carolina.

Merritt, R.W. and K.W. Cummins (eds.). 1996. An introduction to the aquatic insects of North America (3rd ed.). Kendall/Hunt Publishing Co., Dubuque, Iowa.

Rosgen, D. L. 1996. Applied river morphology. Wildland Hydrology, Pagosa Springs, Colorado.

Southeast Regional Climate Center. 2004. Available at www.sercc.com

U.S. EPA (United States Environmental Protection Agency). 2000. A stream condition index for West Virginia wadeable streams, Region 3 Environmental Services Division. Prepared by Tetra Tech, Inc. July 21, 2000. 
U.S. EPA (United States Environmental Protection Agency). 2005. National management measures to control nonpoint source pollution from urban areas. November 2005, EPA841-B-05-004.

Wellman, J. C., D. L. Combs, and S. B. Cook. 2000. Long-term impacts of bridge and culvert construction or replacement on fish communities and sediment characteristics of streams. Journal of Freshwater Ecology 15:317-328.

Wiggins, G. B. 1996. Larvae of the North American caddisfly genera (Trichoptera). University of Toronto Press, Toronto, Canada. 
Table 1. Results of the meta-analysis of Sauerkraut Run and Tributary Stream, Lost River, West Virginia. A positive $d$ value indicates that the downstream site collected a higher percentage of sediment. A* indicates significant chi-square values at $p=0.05$.

\begin{tabular}{lccccc}
\hline & \multicolumn{2}{c}{ Sauerkraut Run } & & \multicolumn{2}{c}{ Tributary Stream } \\
\cline { 2 - 3 } \cline { 5 - 6 } Sediment & & & & & \\
Size Class & 0.49 & & & & \\
\% Size 1 $(>4.70 \mathrm{~mm})$ & -0.13 & 13.28 & & -0.51 & 8.97 \\
\% Size 2 $(>2.28$ to $4.7 \mathrm{~mm})$ & -0.16 & $28.54^{*}$ & & -1.10 & 16.14 \\
\% Size 3 $(>1.40$ to $2.28 \mathrm{~mm})$ & -0.12 & $23.71^{*}$ & & -0.95 & 13.61 \\
\% Size 4 $(0.85$ to $1.40 \mathrm{~mm})$ & -0.45 & 13.34 & & 0.36 & 17.15 \\
\% Size 5 $(<0.85 \mathrm{~mm})$ & -0.46 & 9.92 & & -0.11 & 16.65 \\
\% Fines $(<2.28 \mathrm{~mm})$ & 0.81 & 12.26 & & 0.47 & 13.12 \\
Total $(\mathrm{g})$ & & & &
\end{tabular}


Table 2. Mean seasonal West Virginia Stream Condition Index (WV-SCI) for benthic macroinvertebrates at upstream and downstream sites in Sauerkraut Run and Tributary Stream, Lost River, West Virginia.

\begin{tabular}{lccccc}
\hline Location & \multicolumn{2}{c}{ Sauerkraut Run } & & \multicolumn{2}{c}{ Tributary Stream } \\
\cline { 2 - 3 } \cline { 5 - 6 } Sampling period & WV-SCI & SE & & WV-SCI & SE \\
\hline Downstream & & & & \\
$\quad$ Fall 2002 & 62.73 & 7.29 & & 60.10 & 0.54 \\
Spring 2003 & 79.19 & 3.30 & & 70.44 & 0.04 \\
Fall 2003 & 82.83 & 0.83 & & 49.30 & 2.77 \\
Spring 2004 & 71.22 & 4.42 & & 76.95 & 4.49 \\
& & & & & \\
Upstream & & & & & \\
Fall 2002 & 71.97 & 6.33 & & 59.35 & 7.37 \\
Spring 2003 & 79.64 & 4.27 & & 70.97 & 1.41 \\
Fall 2003 & 87.79 & 4.85 & & 56.18 & 0.00 \\
Spring 2004 & 77.83 & 6.33 & & 72.66 & 4.30 \\
\hline
\end{tabular}


Table 3. Regression coefficients associated with linear regression analysis of benthic macroinvertebrate WV-SCI scores and sediment data from Sauerkraut Run and Tributary Stream, Lost River, West Virginia.

\begin{tabular}{lccccc}
\hline \multirow{2}{*}{$\begin{array}{l}\text { Sediment } \\
\text { size class }\end{array}$} & \multicolumn{2}{c}{ Sauerkraut Run } & & \multicolumn{2}{c}{ Tributary Stream } \\
\cline { 2 - 3 } \cline { 5 - 6 } \% & Downstream & Upstream & & Downstream & Upstream \\
\hline \% Size 1 & 0.340 & 0.033 & & 0.071 & 0.006 \\
\% Size 2 & 0.166 & 0.022 & & 0.150 & 0.554 \\
\% Size 3 & 0.004 & 0.085 & & 0.056 & 0.012 \\
\% Size 4 & 0.132 & 0.054 & & 0.001 & 0.045 \\
\% Size 5 & 0.635 & 0.007 & & 0.202 & 0.127 \\
\% Fines & 0.505 & 0.003 & & 0.001 & 0.055 \\
Total (g) & 0.448 & 0.050 & & 0.008 & 0.001 \\
\hline
\end{tabular}


Figure 1. The percent of fine sediment and total amount of sediment collected at upstream and downstream sites on Sauerkraut Run and Tributary Stream. Vertical bars indicate plus and minus one standard error; $\mathrm{a} *$ indicates significant difference between sites $(p \leq$ $0.05)$. 


\section{Figure 1.}

\section{Sauerkraut Run}
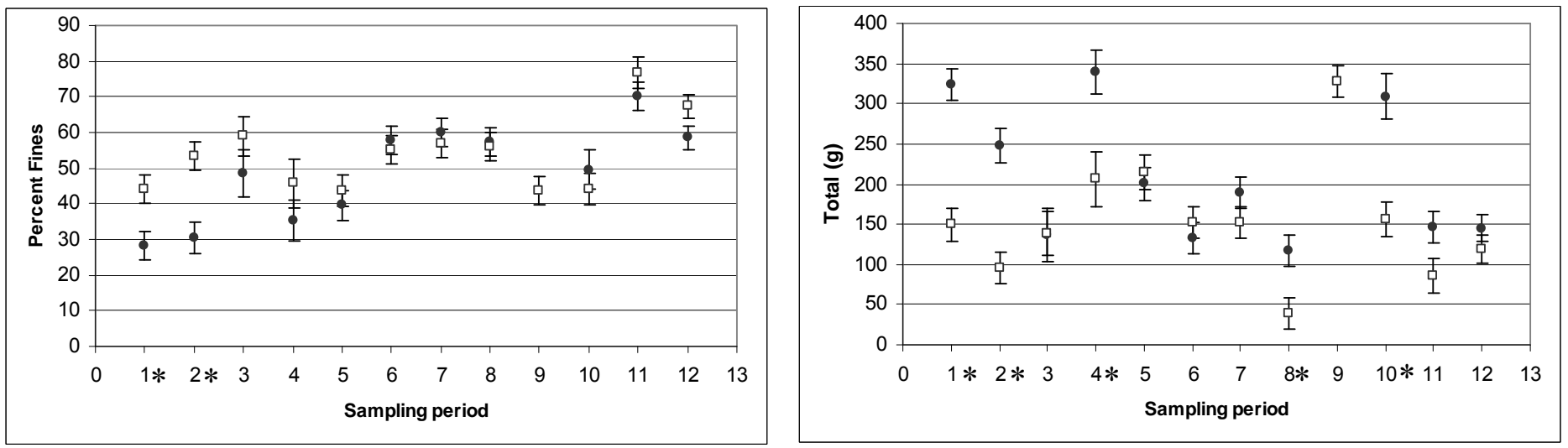

\section{Tributary Stream}
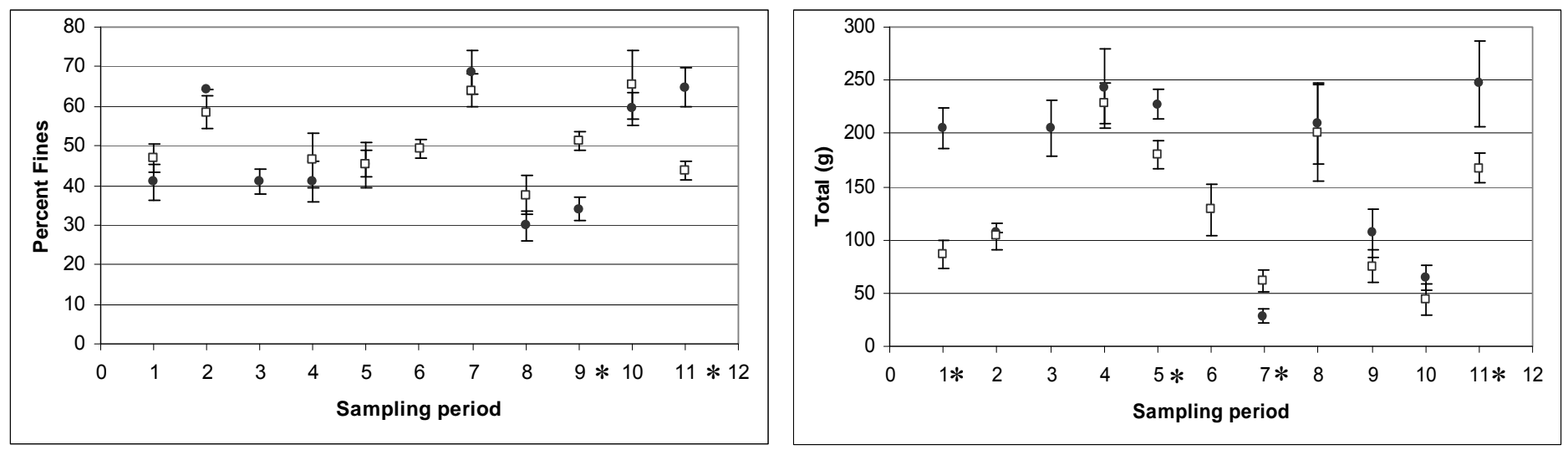


\section{Chapter 5 - Influences of High Flow Events on a Stream Channel Altered by Construction of a Highway Bridge - A Case Study ${ }^{1}$}

${ }^{1}$ This chapter is formatted in the style of the Annals of the Association of American Geographers 


\begin{abstract}
Impacts of highway construction on streams in the central Appalachians are a growing concern as new roads are created to promote tourism and economic development in the area. Alterations to the streambed of a first order stream, Sauerkraut Run, Hardy County, West Virginia (USA) during construction of a highway overpass included placement and removal of a temporary culvert, straightening and regrading of a section of stream channel, and armorment of a bank with a gravel berm. We surveyed longitudinal profiles and cross sections in a reference reach and the altered reach of Sauerkraut Run from 2003 through 2007 to measure changes in the streambed. During the four-year period, three high flow events changed the streambed downstream of construction including channel widening and aggradation and then degradation of the streambed. Upstream of construction, at the gravel berm, bank erosion was documented. The reference section remained relatively unchanged. Knowledge gained by documenting channel changes in response to natural and anthropogenic variables can be useful for managers and engineers involved in highway construction projects.
\end{abstract}

Key words: Highway construction; longitudinal profile; stream channel alteration 


\section{Introduction}

Natural channels are achieved by allowing a stream to develop a stable dimension, pattern and profile. In a stable system, the streambed neither aggrades nor degrades, and its sediment load is consistently transported (Schumm 1977, Allen 1995). Channel instability occurs when a streambed is degraded by scouring processes, or excessive sediment deposition leads to aggradation (Rosgen 1996). Wolman (1967) initially categorized stages of stream channel change in response to urbanization. The first stage is equilbrium and stream channel stability. As development and construction begin in the second stage, sediment delivery rates increase leading to channel aggradation. The third stage is an urban landscape with increased areas of impervious surfaces leading to decreased sediment inputs and channel degradation due to flashy discharg and low sediment yield (Wolman 1967). Subsequent studies on effects of urbanization indicate that stream channels respond to early stages of construction by an increase in sediment influx resulting from erosion of exposed, unvegetated channel banks (Urban and Rhoades 2003) and the land surface due to recontouring and leveling (Wohl 2000). Enlargement of the floodplain can occur as sediment material that the stream can not carry is deposited as floodplain alluvium (Graf 1975). Response to increased urbanization includes channel widening (Hammer 1972, Grabel and Harden 2006, Colosimo and Wilcock 2007), channel incision (Booth 1990, Doyle et al. 2000), erosion of unarmored banks, and aggradation of the streambed (Hess and Johnson 2001, Grabel and Harden 2006, Colosimo and Wilcock 2007).

Road construction along stream corridors alters the structure, function, and stability of stream channels (King and Ball 1965, Albanese and Matlack 1998). Road crossings such as bridges and culverts can influence stream hydraulics and sediment transport (Duck 1985, Johnson 2002, Johnson 2006). Bridges can either be single span, with no pillars in the stream, or 
multiple span, with one or more pillars in the stream. Pillars in the stream alter the natural flow regime and cause scouring upstream, and deposition downstream. Bridges and culverts often restrict flow across the floodplain due to high embankments or approaches to the bridge or culvert. A stream channel that was straightened and constricted with steep banks may not allow flow to cross into the floodplain. The importance of the floodplain is to dissipate the energy of flows exceeding the effective discharge (Ward et al. 2002). If a culvert is present, the water can back up upstream creating localized channel widening. If the flow is forced to remain in the channel instead of intercepting the floodplain, it will increase the sheer stress and velocity, resulting in bank erosion and bank failure, and streambed degradation (Graf 1975, Richardson and Davis 2001, Johnson 2002). Roads that cross a stream at mid slope and bridge spans built on cut and fill material can be sources for debris flows. Debris flows are rapid movements of soil, sediment, and organic matter down steep stream channels. Heavy rain events can trigger landslides of the fill material, and if near a stream, can result in a debris flow. Debris flows can move downstream, encounter a road or culvert, and either continue movement of fill downstream or deposit it. The major impact of debris flows is movement and rearrangement of sediment. Debris flows mainly occur during floods and are most severe on small, steep stream segments (Jones et al. 2000). If the stream can not carry the sediment load, it may be deposited on the floodplain, creating new areas, and enlarging current areas by vertical accretion (Graf 1975). The stability of a stream is associated with a balance between variables such as width, depth, velocity, slope, sediment volumes and sediment sizes. Changes in a streams dimension, pattern, and profile due to changes in these variables can result in deteriorated water quality (US EPA 1994, Trimble 1997), reduction in quality and diversity of habitat and negative impacts on the aquatic communities (Rabeni and Smale 1995; Jones et al. 1999), and land loss through 
erosion (Hammer 1972, Rosgen 1996). Monitoring a stream over time can be used to determine if the stream is aggrading, degrading, or laterally eroding, and can provide information on the response of a stream to alteration. This article presents a case study of a first order stream that was altered by channelization, placement and then removal of a culvert, and creation of a gravel berm in association with construction of a highway overpass. During construction of a highway overpass across the stream, four periods of high flows were documented. We present data collected from a reference reach upstream of construction, and an altered reach within and downstream of the construction. Response of the streambed to construction activity and high flow events was documented.

\section{Site Description}

Sauerkraut Run, a tributary to the Lost River, is located in the eastern panhandle of West Virginia (Figure 1). This first order stream is paralleled by a rural road and is culverted in several locations. Sauerkraut Road was included into the state highway system by legislative action in the 1930s. Prior to that, it was maintained by the county as a dirt and gravel road. In 1999, it was surface treated with asphalt, and the downstream most section was channelized.

Construction over Sauerkraut Run began in April 2002, and a temporary culvert was placed across the stream for heavy machinery and construction crews. Streamside vegetation was cleared along a $100 \mathrm{~m}$ stretch within the construction zone, and a gravel berm was created to direct the stream flow through this channelized reach.

During this study, Sauerkraut Run experienced four high flow events. Flow was obtained from a USGS gauge located on Waites Run, a neighboring tributary of the Lost River. There was a high correlation $\left(r^{2}=0.98\right)$ between flow data collected on site and data obtained from the 
USGS gauge. High flows during November 2002 created a scouring event downstream of the culvert, changing the morphology of the streambed. The eastern panhandle of West Virginia received 7.5 to $10 \mathrm{~cm}$ of total precipitation between September 19 and 21, 2003 (Southeast Regional Climate Center, www.sercc.com) as a result of Hurricane Isabel's influence, and in December 2003, a third period of high flow was recorded. During the first week of September 2004, heavy rains and high flows resulting from the effects of Hurricane Frances caused Sauerkraut Run to reach flood stage. The stream washed out many of the state crossings, and ran over the road in several places. The West Virginia Division of Highways repaired the road and stabilized culverts during the week of September 6-10, 2004. They also removed the temporary culvert.

\section{Methods}

We surveyed a longitudinal profile of Sauerkraut Run during July 2004, October 2004, November 2005, and March 2007. The survey covered $670 \mathrm{~m}$ of stream length, beginning one channel unit upstream from the most upstream cross section, at the head of a pool, and continuing to the State Route 55 bridge located downstream from highway construction. The longitudinal profile consisted of a reference reach (approximately $330 \mathrm{~m}$ ) and an altered reach (approximately $337 \mathrm{~m}$; Figure 2). We surveyed the longitudinal profile with an engineering level and survey (stadia) rod, and established permanent bench marks where necessary along the stream to enable the surveyor to view the rod throughout the length of the profile. At the beginning of each channel unit (head of riffle, head of run, head of pool), features including left bank full, left edge of water, thalweg, water surface, right edge of water, and right bank full, were surveyed. 
We established four cross sections on Sauerkraut Run, two in each of the reaches: a reference reach upstream of construction, and an altered reach downstream of construction. Reference Reach 1 cross section was located upstream from a permanent culvert on Sauerkraut Run; Reference Reach 2 cross section was located at an upstream site with unaltered banks of native vegetation; Altered Reach 1 cross section was located upstream from the site of a temporary culvert (removed in September 2004) at a reinforced gravel stream bank; and Reference Reach 2 cross section was located downstream from the temporary culvert. We originally surveyed cross sections in 2003 , and resurveyed them in 2004,2005 , and 2007 . We took distance and elevation readings at $0.305 \mathrm{~m}$ intervals, at obvious breaks in the slope, and at major features associated with the stream, including bankfull, edge of water, thalweg, and any bar formations. At each monumented cross section, a permanent bench mark (a piece of $1.25 \mathrm{~cm}$ diameter rebar driven into the ground) was established on a stable site above the bank full channel, and elevations were referenced to the local benchmark.

Changes over time in cross sections determine vertical stability of the streambed, and differences over time in the longitudinal profile document changes in stream length, gradient, riffle frequency, and maximum pool depth. We determined the change in cross sectional area $(\triangle \mathrm{A})$ as scour or degradation (a negative value) or as fill or aggradation (a positive value). We also used four indices described by Olson-Rutz and Marlow (1992) to assess changes in stream cross sections: net percent change in area, absolute percent change in area, width/depth ratio, and Gini coefficient.

Net percent change in area $(\Delta \mathrm{A} \%)$ quantifies the net change in cross-sectional area of a transect. It can be a positive or negative value depending on whether the channel is experiencing aggradation and degradation. However, if erosion in one part of the channel equals the amount 
of deposition in another, the value could approach zero, indicating little change in the stream channel. The absolute percent change in area $(|\Delta \mathrm{A} \%|)$ quantifies cumulative channel change $((|\Delta \mathrm{A} \%|)=$ erosion + deposition $)$, and represents the total amount of streambed material movement between two surveying date. The width/depth ratio $(\mathrm{w} / \mathrm{d})$ is a relative index of channel shape. Width is the total distance across the channel and depth is the mean depth of the channel. Channels with high w/d ratios tend to be shallow and wide, and those with low w/d ratios tend to be narrow and deep. The Gini coefficient $(\mathrm{G})$ describes changes to channel crosssectional shape. The direction and magnitude of change in the Gini coefficient over time describes whether a channel is becoming wider and shallower or narrower and deeper in response to management or natural events. Wide flat channels have low $\mathrm{G}$ values, and deep narrow channels have G values near 1. When the Gini coefficient is calculated from pre- and post-treatment scenarios, the difference (diff) in $\mathrm{G}$ (Gdiff = Gpost - Gpre) describes the direction of channel change. Positive differences indicate the channel is becoming deeper and narrower. Negative differences indicate the channel is becoming shallower and wider (Olson-Rutz and Marlow 1992).

Measurements must be taken at identical points along the transect to compare different dates. Data collected were aligned at $0.305 \mathrm{~m}$ intervals, and any points missing were extrapolated using distance and depth from closest known points on either side. Data may have become misaligned in the field when important features, such as gravel bars, were surveyed in at smaller increments than $0.305 \mathrm{~m}$.

Stream cross section measurement dates were given a designation of Post High Flow or Normal Flow. Post high flow designation meant that a high flow event occurred during the time period between the two sampling events, otherwise a designation of normal flow was used. Flow 
data were obtained from a USGS gauge located on Waites Run, a neighboring tributary of the Lost River. We compared stream cross sectional area, and other indices ( $\Delta \mathrm{A} \%$ and $|\Delta \mathrm{A} \%|)$ for Post High Flow and Normal Flow cross sections at reference and altered locations using analysis of variance (ANOVA).

At three of the cross sections (reference, upstream, and downstream) three metal-link scour chains were established across the stream (Lisle and Eads 1991; Laronne et al. 1994). The chains were installed vertically in the streambed: a duckbill anchor attached to a $0.6-\mathrm{m}$ long section of galvanized chain was driven into the streambed with a drive rod. We removed extra exposed chain with a pair of metal cutters so that only two links remain exposed. One scour chain was placed near the right edge, one near the center of the stream, and one near the left edge of the stream. Locations of the scour chains were surveyed in as features in the monumented cross sections. Scour was monitored by counting the number of chain links exposed after a highflow event. We measured fill by determining the thickness of the sediment layer deposited on top of the originally exposed links. Scour chains also can be used to detect scour-before-fill. When a streambed is first scoured it will expose some links that will lie horizontally. If the streambed is then subjected to sediment deposition, those links will be buried.

\section{Results}

\section{Longitudinal Profile}

Within the $330 \mathrm{~m}$ reference reach there was a braided section approximately $61 \mathrm{~m}$ in length and located at $223 \mathrm{~m}$. This section had three channels: a right, left, and mid channel. During the first two surveys in August and September 2004, most water flowed down the middle channel. In November 2005 most of the flow was down the channel on river right. The reaches 
upstream and downstream of the braided channel had degraded approximately 0.1 to $0.3 \mathrm{~m}$ and the middle channel was closed due to a debris jam. The channel on river right was approximately 0.3 to $0.6 \mathrm{~m}$ lower in elevation than the middle channel. In March 2007 we surveyed the center channel again. A gravel bar and snag pile had closed off the right channel, and most of the stream flow was traveling down the center channel. The length of the middle channel was classified as a long riffle in August 2004. When it was surveyed again in September 2004, we noted several small pools. In 2007 the middle channel was again classified as one continuous riffle and the channel thalweg had aggraded approximately $0.6 \mathrm{~m}$ (Figure 2).

The altered reach of Sauerkraut Run from the gravel berm downstream to the State Route 55 bridge (330 to $677 \mathrm{~m}$ ) went through several changes during the 4 years of the study (Figure 2). The culvert was removed in September 2004. Upstream of the culvert was a long straight channelized riffle section. Once the culvert was removed, the riffle section upstream remained at the same elevation, however, downstream the thalweg aggraded (Figure 2), as a result of artifical regrading of the stream channel with removal of the culvert. The scour pool located below the culvert was filled. Our survey in November 2005 indicated that the long riffle section was forming several small pools, and the entire altered reach degraded between 0.3 to 0.6 meters. A small pool was formed at the bed in the stream below the removed culvert. More degradation (about $0.3 \mathrm{~m}$ ) occurred upstream of the previous culvert between 2005 and 2007, and a deep pool was scoured out at the bend downstream of the removed culvert similar to the pool surveyed in July 2004. 


\section{Cross sectional surveys}

Three cross sectional surveys were taken at Reference Reach 1 and Altered Reach 1, and five were taken at Reference Reach 2 and Altered Reach 2. Two survey periods were designated as high flow: the period between October 18, 2003 and February 22, 2004 and the period between June 11, 2004 and September 26, 2004. The discharge on Waites Run was $4.90 \mathrm{~m}^{3}$ per second on December 11, 2003. The average for December 2003 was $1.03 \mathrm{~m}^{3}$ per second. Discharge on Waites Run was $7.05 \mathrm{~m}^{3}$ per second on September 9, 2004, $2.89 \mathrm{~m}^{3}$ per second on September 9, 2004 and 4.16 on September 18, 2004. Average for September 2004 was $1.12 \mathrm{~m} 3$ per second. Reference 2 and Altered 2 were measured on February 22, 2004 and all cross sections were surveyed on September 26, 2004. Data from cross section measurements were separated into four categories: Reference Normal Flow $(\mathrm{n}=5)$, Reference Post High Flow $(\mathrm{n}=$ 3), Altered Normal Flow $(\mathrm{n}=5)$, and Altered Post High Flow $(\mathrm{n}=3)$.

There was little change in cross sectional area post high flow events at Reference Reach 1 and 2 (Figure 3), slight aggradation took place. There was little to no change in $\mathrm{w} / \mathrm{d}$ or in channel shape $\left(\mathrm{G}_{\mathrm{diff}}\right)$. Cross section surveys taken post high flow in the altered reach indicated more cross sectional area change. Altered Reach 1 had a moderate amount of net percent change $(\Delta \mathrm{A} \%)$; however, the absolute amount of aggradation and degradation was greatest at this site

(Figure 4). Altered Reach 2 experienced degradation during each high flow event (Figure 4). Despite changes in area, w/d and channel form (G) did not change a lot over time. Reference Reach 1 and Altered Reach 1 were characterized by deeper, narrow channels and higher G coefficients. Reference Reach 2 and Altered Reach 2 were more shallow and wide (Figure 3 and 4). The Altered Post High Flow cross sections had a significantly greater change in area, $\Delta \mathrm{A} \%$ and $|\Delta \mathrm{A} \%|$ (Table 1), all other treatments were similar regardless of flow events. 


\section{Scour Chains}

Scour chain were only relocated at the reference cross section in September 2004. Of the three chains placed across the stream, only two were located. The chains were buried under 1 $\mathrm{cm}$ of gravel. However, when uncovered, three links were exposed indicating scour before deposition. The third had been buried under a gravel bar, and could not be found. Scour chains at other cross sections have been buried by gravel bars, or in the case of the downstream cross section, were located under very large boulder substrate. We attempted to find scour chains that had been buried under gravel bars with a metal detector, and were unsuccessful. We did not attempt to relocate scour chains again after September 2004.

\section{Discussion}

We did not begin morphological surveys of Sauerkraut Run until October 2003. However, monitoring of sedimentation of the stream took place between July 2002 and December 2004 (Hedrick et al. 2007). Removal of streamside vegetation and re-grading of the mountain slopes to create the overpass increased runoff into Sauerkraut Run during beginning stages of construction. The downstream site accumulated significantly greater amounts of sediment in 2003, prior to installation of sediment fencing (Hedrick et al. 2007). Although measurements were not taken, changes to the streambed downstream of the culvert were photo documented in 2002 and 2003. The streambed was dominated by cobble and boulder substrate in spring 2002. A high flow event in November 2002 moved the large alluvial material and degraded the streambed (Figure 5). In September 2003, heavy rain related to effects of a hurricane created a high flow event that aggraded the streambed and deposited a gravel bar on 
river right (Figure 5). This gravel bar was surveyed in the first cross section conducted in October 2003.

Channel aggradation is a common scenario in early stages of road construction and urbanization (Hammer 1972, Graf 1975, Gregory et al. 1992). Urban and Rhoades (2003) compared channelized to natural stream reaches of the Embarrass River in Illinois. Stream cross sections were surveyed in stream reaches before and after channelization, and before and after a sustained bankfull flow. They found most channel segments were stable. The greatest influence on the change in channel location throughout the Embarrass watershed was straightening of the channel, and main channel response was characterized by slight net aggradation. This was attributed to an increase in sediment influx resulting from erosion of exposed, unvegetated channel banks. Grabel and Harden (2006) studied the impacts of human induced changes to the channel of Second Creek, in Knoxville, Tennessee. Changes included deliberate channel realignment, and channelization of some reaches through culverts and cement lined channels. The entire watershed has been urban for about 60 years, however new projects, including highway construction, rebuilding and repairing portions of the channel are continually taking place. In a four year study from 1997 to 2001, they found no upstream-downstream trend of erosion or deposition, however, cross sections indicated a downstream trend of increasing width and area. Channel widening resulting from bank erosion was the dominant accommodation to higher volume peak flows in Second Creek. Erosion was restricted to unarmored banks, and aggradation most often occurred in cement culverts and concrete lined channels. Channel widening has been documented by studies done in a variety of areas and levels of urbanization. Hammer (1972) found an original increase in sediment followed by increase in discharge, downcutting and channel widening in an urbanizing watershed in eastern Pennsylvania. Pizzuto 
et al. (2000) also studied streams in Pennsylvania. Paired urban and rural catchments did not differ in slope of bed or mean bankfull depth. However, bankfull width was larger for urban channels. Similar results were found by Hollis and Luckett (1976) in southeast England, Neller (1988) in New South Wales in Australia, and Henshaw and Booth (2000) in Puget Sound in Washington.

The channel changes in Sauerkraut Run were related to high flow events. Major degradation of the downstream channel and increased bankfull depth occurred between October 18, 2003 and February 20, 2004, following a period of high flow in December 2003. Discharge on Waites Run, a neighboring stream in Lost River watershed with a USGS gauge, was $4.90 \mathrm{~m}^{3}$ per second on December 11, 2003. The average for December was $1.03 \mathrm{~m}^{3}$ per second.

Between 11 June 2004 and 26 September 2004 the stream bank on the left of the mid cross section site located at the armored gravel berm was severely eroded. This should have widened the stream channel, however, deposition of a gravel bar on the right side actually caused the streambed to become entrenched. The armored bank on the right side of the downstream cross section also was eroded, causing channel widening. Stream channel changes resulted from high flows due to the effects of Hurricane Frances. Stream discharge on Waites Run was measured at $7.05 \mathrm{~m}^{3}$ per second on 8 September 2004 and $2.89 \mathrm{~m}^{3}$ per second on 9 September 2004. Little change was documented at the reference cross section (a small amount of deposition was noted), and no change occurred at the upstream cross section. In the reference reach of Sauerkraut Run the stream is connected to its floodplain and not constricted by artificial stream banks. Entrenchment continued at the mid cross section site, and thalweg depth increased between September 2004 and November 2005. 
Similar results were found by Robinson and Barry (2001) who conducted a series of cross-sectional surveys on streams on the Wenatchee National Forest prior to flooding during winter of 1995 to 1996, and then resurveyed post flooding. The Duechesne River in Utah responded to a period of flooding between 1981 and 1987 with channel widening and bed aggradation of gravel bed channels (Gaumen et al. 2006). In another study in the central Appalachians, Hicks et al. (2005) found that a brief flash flood produced significant channel change in the small catchment of Saul's Run, West Virginia.

Nelson et al. (1996) described changes to urban stream channels located in the Piedmont Region of Pennsylvania and Maryland following high flow from Hurricane Agnes in 1972. In the Patuxent River basin in Maryland channel widening, removal of all but the coarsest material in the streambed, and destruction of the floodplain vegetation took place. In other areas, such as the Conestoga Basin in southeastern Pennsylvania and Dead Run in Baltimore County, Maryland, little change to stream cross sections was noted (Nelson et al. 1996). Western Run, in north-central Baltimore, also experienced channel widening during Hurricane Agnes. However, within one year of the flood, channel cross-sections were rapidly recovering back to pre-flood dimensions (Costa 1974). Streams dominated by bedrock outcrops and coarse bed and bank material such as the Conestoga Basin, Dead Run (Nelson et al. 1996) and Gilmore Creek, southeastern Australia (Page et al. 2007) experienced less channel incision and stream widening during high flow periods.

Changes in the streambed can impact the health and habitat available for fish and benthic maroinvertebrates. Aggradation and excessive stream sedimentation can alter community composition and abundance of aquatic biota (Rabeni and Smale 1995; Jones et al. 1999), decreases reproductive success and survival of fishes (Scrivener and Brownlee 1989; O'Conner 
and Andrew 1998), decreases survival of benthic macroinvertebrates due to deposition of silt on the gills (Lemly 1982) and impact feeding performance of fishes (Sweka and Hartman 2001). Degradation of the streambed can eliminate current habitat and change the composition of the stream substrate. Abundances of benthic macroinvertebrates generally increase across the particle series of sand-gravel-pebble-cobble. However, a more functional relation can be made between invertebrate abundance and substrate heterogeneity. Abundances are least in homogeneous sand or silt, or in large boulders and bedrock. A mixture of gravel, pebbles, and cobble provide the best habitat for benthic macroinvertebrate abundance (Brusven and Prather 1974, Minshall 1984).

Hedrick et al. (2007) calculated the West Virginia Stream Condition Index (WV-SCI) scores for benthic macroinvertebrate samples collected on Sauerkraut Run. The WV-SCI is a multi-metric index developed specifically for West Virginia wadeable streams (U. S. EPA 2000), and includes six normalized metrics using family level data — EPT (Ephemeroptera, Plecoptera, Trichoptera) taxa, total taxa, \% EPT, \% Chironomidae, \% of the top two dominant taxa, and HBI (Hilsenhoff Family Biotic Index). The normalized metric scores range from 0 to 100 and are categorized as $>78-100=$ very good; $>68-78=$ good; $>45-68=$ fair; $>22-45=$ poor; and 0 - 22 = very poor. The WV-SCI scores from samples collected downstream of construction in July and October 2002 indicated benthic macroinvertebrate communities in "fair" biotic condition. These samples were collected prior to sediment fencing at the construction site and during a time period when sediment accumulation was significantly greater at the downstream site (Hedrick et al. 2007). The WV-SCI scores increased to "good" following implementation of sediment control, however, scores of "fair" were recorded again in December 2003 following the 
episode of high flow and scouring of the stream bed. The WVSCI scores from samples collected upstream remained good to very good throughout the study.

Unlike many other studies involving streams impacted by road construction and urbanization, Sauerkraut Run has not been affected by many of the factors associated with urbanization that follow post construction. With the exception of the area within the construction zone, which was straightened and had streamside vegetation removed (Figure 6), the stream riparian area was relatively unharmed. There was no increase in impervious surfaces and currently no increase in the residential homes along the stream. Without further impacts, the streambed in the altered reach may continue to stabilize and habitat in the form of pool and riffle complexes should form. Streams altered by incision and channelization tend to degrade until the critical bank height is exceeded and the bank fails. This increases channel width and sediment load. However, over time, the stream will move toward a new equilibrium and incision will cease (Fischenich and Morrow 2000, Henshaw and Booth 2000). Most stable reaches are associated with the return or colonization of natural vegetation or when degradation is halted because the substrate becomes coarse enough to prevent further incision. Henshaw and Booth (2000) found that streams in developed and developing watersheds in the Puget Sound area, Washington, stabilized within 10 years. Some streams stabilized in as little as 3 years if land use remained constant. However, bank armorment and disconnection of Sauerkraut Run may continue to create a sediment imbalance, forcing the stream to erode still exposed banks during periods of high flow.

Sauerkraut Run responded to effects of road construction, including channelization and disruption of the floodplain, with a variety of changes varying from aggradataion, entrenchment and channel widening, and bed lowering. On a study of Monks Brook catchment, England, 
Gregory et al. (1992) found that channel response to urbanization varied from vertical erosion to lateral erosion to combinations of the two. The adjusting stream channel changes were not equal along the entire length of affected channel. Channel adjustment due to human activity may be of different kinds and spatially discontinuous, and variability can occur along the length of the channel that is changing as a result of urbanization. Even small changes in imperviousness associated with construction can cause increases in severe channel stability (Bledsoe and Watson 2001). Changes such as increases in width, and bed lowering in the downstream altered reach of Sauerkraut Run were similar to changes found in other studies involving road construction. Knowledge of how streams in the Appalachian area respond to urbanization will be useful to managers and engineers throughout the remainder of the highway project currently underway and other construction projects in the future.

\section{Acknowledgements}

This research was funded in part by the West Virginia Division of Highways. We thank Dr. Steve Kite, West Virginia University, Department of Geology, for assistance in manuscript preparation, and Jim Hedrick, West Virginia Division of Natural Resources, for invaluable help in field collections. Thanks to Kerry Bledsoe, Dr. Pat Mazik, and Dr. Todd Petty and for review of the manuscript. Reference to trade names does not imply endorsement of commercial products by the U.S. government. 


\section{Literature Cited}

Allen, J. D. 1995. Stream Ecology: Structure and Function of Running Waters. Chapman and Hall, Oxford, Great Britian.

Bledsoe, B. P. and C. C. Watson. 2001. Effects of urbanization on channel instability. Journal of the American Water Resources Association 37:255-270.

Booth, D. B. 1990. Stream-channel incision following drainage-basin urbanization. Water Resources Bulletin 26: 407-417.

Brusven, M. A. and K. V. Prather. 1974. Influence of stream sediment on distribution of macrobenthos. Journal of Entomological of Society British Coloumbia 71:25-32.

Costa, J.E. 1974. Response and recovery of a Piedmont watershed from Tropical Storm Agnes, June 1972. Water Resources Research 10:106-112.

Doyle M.W., J. M. Harbor, C. F. Rich, and A. Spacie. 2000. Examining the effects of urbanization on streams using indicators of geomorphic stability. Physical Geography 21(2): 155-181.

Duck, R. W. 1985. The effect of road construction on sediment deposition in Loch Earn, Scotland. Earth Surface Processes and Landforms 10:401-406.

Fischenich, J.C. and J. V. Morrow. 2000. Reconnection of floodplains with incised channels," EMRRP Technical Notes Collection (ERDC TN-EMRRP-SR-09), U.S. Army Engineer Research and Development Center, Vicksburg, MS.

Gaeuman, D., J. C. Schmidt, and P. R. Wilcock. 2005. Complex channel responses to change in stream flow and sediment supply on the lower Duchesne River, Utah. Geomorphology 64:185-206. 
Grabel, J. L., and C. P. Harden. 2006. Geomorphic response of an Appalachian valley and ridge stream to urbanization. Earth Surface Processes and Landforms 31: 1707-1720

Graf, W. L. 1975. The impact of suburbanization on fluvial geomorphology. Water Resources Research 11: 690-692.

Gregory, K. J., R. J. Davis, and P. W. Downs. 1992. Identification of river channel change due to urbanization. Applied Geography 12:299-318.

Hammer TR. 1972. Stream channel enlargement due to urbanization. Water Resources Research 8: $1530-1540$.

Hedrick, L.B., S. A Welsh, and J. T. Anderson. 2007. Effects of highway construction on sediment and benthic macroinvertebrates in two tributaries of the Lost River, West Virginia. Journal of Freshwater Ecology 22:561-569.

Henshaw, P. C. and D. B. Booth. 2000. Natural restabilization of stream channels in urban watersheds. Journal of the American Water Resources Association 36:1219-1236.

Hess, A. J., and P. A. Johnson. 2001. A systematic analysis of the constraints to urban stream enhancements. Journal of the American Water Resources Association 37:213-221.

Hicks, N.S., J. A. Smith, A. J. Miller, and P. A. Nelson. 2005. Catastrophic flooding from an orographic thunderstorm in the central Appalachians. Water Resources Research 41: DOI:10.1029/2005WR004129.

Hollis, G. E. and J. K. Luckett. 1976. The response of natural river channels to urbanization: two case studies from southeast England. Journal of Hydrology 30:351-363.

Johnson, P.A. 2000. Incorporating road crossings into stream and river restoration projects. Ecological Restoration 20:272-277. 
Johnson, P. A. 2006. Physiographic characteristics of bridge-stream interactions. River Research and Applications 22: 617-630.

Jones, E. B.D. III, G. S. Helfman, J. O. Harper, and P. V. Bolstad. 1999. Effects of riparian forest removal on fish assemblages in southern Appalachia streams. Conservation Biology 13:1454-1465.

Jones, J. A., F. J. Swanson, B. C. Wemple, and K. U. Snyder. 2000. Effects of roads on hydrology, geomorphology, and disturbance patches in stream networks. Conservation Biology 14:76-85.

Laronne, J. B., D. N. Outhet, P. A. Carling, and T. J. McCabe. 1994. Scour chain deployment in gravelbed rivers. Catena 22: 299-306.

Lemly, D. A. 1982. Modification of benthic insect communities in polluted streams: combined effects of sedimentation and nutrient enrichment. Hydrobiologia 87:229-245.

Lisle, T. E., and R. E. Eads. 1991. Methods to measure sedimentation of spawning gravels. United States Department of Agriculture, Forest Service, Pacific Southwest Research Station Berkley, CA, USA. Research Note PSW-411.

Minshall, G. A. 1984. Aquatic insect-substratum relationships. Pages 358-400 in Resh, V. H., and D. M. Rosenberg, editors. 1984. The ecology of aquatic insects. Praeger Publishers, New York, USA.

Neller, R. J. 1988. A comparison of channel erosion in small urban and rural catchments, Armidale, New South Wales. Earth Surface Processes and Landforms 13:1-7.

Nelson, P. A., J. A. Smith, and A. J. Miller. 2006. Evolution of channel morphology and hydrologic response in an urbanizing drainage basin. Earth Surface Processes and Landform 31:1063-1079. 
O’Conner, W. C. K., and T. E. Andrew. 1998. The effects of siltation on Atlantic salmon, Salmo salar L., embryos in the River Bush. Fisheries Management and Ecology 5:393401.

Olson-Rutz, K. M. and C. B. Marlow. 1992. Analysis and interpretation of stream channel cross-sectional data. North American Journal of Fisheries Management 12:22-61.

Page, K., P. Frazier, T. Pietsch, and R. Dehaan. 2007. Channel changes following European settlement: Gilmore Creek, southeastern Australia. Earth Surface Processes and Landform 32:1398-1411.

Pizzuto, J. E., W. C. Hession, and M. McBride. 2000. Comparing gravel-bed rivers in paired and rural catchments of southeastern Pennsylvania. Geology 28:79-82.

Rabeni, C. F. and M. A. Smale. 1995. Effects of siltation on stream fish and the potential mitigating role of the buffering zone. Hydrobiologia 303:211-219.

Richardson, E.V., and Davis, S.R. 2001. Evaluating scour at bridges. Fourth edition: Federal Highway Administration Hydraulic Engineering Circular No. 18, FHWA-IP-90-017.

Robinson, T. A., and J. Barry. 2001. Geomorphic survey of eastern Cascade streams before and after 1995-1996 floods. Forest Ecology and Management 143:57-64.

Rosgen, D.L. 1996. Applied River Morphology. Wildland Hydrology Books, Pagosa Springs, Colorado, USA.

Schumm, S. A. 1977. The Fluvial System. John Wiley and Sons, New York, New York, USA. Scrivener, J. C., and M. J. Brownlee. 1989. Effects of forest harvesting on spawning gravel and incubation of chum (Oncorhynchus keta) and coho salmon (O. kisutch) in Carnation Creek, British Columbia. Canadian Journal of Aquatic Sciences 46:681-696. 
Sweka, J. A., and K. J. Hartman. 2001. Influence of turbidity on brook trout reactive distance and foraging success. Transactions of the American Fisheries Society 130:138-146.

Trimble, S. W. 1997. Contribution of stream channel erosion to sediment yield from an urbanizing watershed. Science 278:1442-1444.

Urbana, M. A., and B. L. Rhoads. 2003. Catastrophic human-induced change in stream-channel planform and geometry in and agricultural watershed, Illinois, USA. Annals of the Association of American Geographers 93:783-796.

U.S. EPA (United States Environmental Protection Agency). 2000. A stream condition index for West Virginia wadeable streams, Region 3 Environmental Services Division. Prepared by Tetra Tech, Inc. July 21, 2000.

U. S. EPA (United States Environmental Protection Agency). 1994. National water quality inventory: 1992 report to Congress. EPA Report 841R94001, Washington, D.C.

Ward, A., D. Mecklenburg, J. Mathews, D. Farver. 2002. Sizing stream setbacks to help maintain stream stability. American Society of Agricultural Engineers Meeting Paper No. 022239. St. Joseph, Michigan:ASAE.

Wohl, E. E. 2000. Mountain Rivers. American Geophysical Union, Washington, D.C. 320 pp.

Wolman, M. G. 1967. Cycle of sedimentation and erosion in urban river channels. Geografiska Annaler 49(A): 385-395. 
Table 1. Stream cross sectional measurements associated with the Reference Reach and Altered Reach on Sauerkraut Run, Hardy County, West Virginia. $\Delta \mathrm{A}$ is the measured change in area, $\Delta \mathrm{A} \%$ is the change in percent of stream cross sectional area, $|\Delta \mathrm{A} \%|$ is the absolute value of the percent change in stream cross sectional area. Values with different letters within a column are significantly different $(\mathrm{p}<0.05)$.

\begin{tabular}{lcccc}
\hline & $\begin{array}{l}\text { Number of Cross } \\
\text { Sections Measured }\end{array}$ & $\Delta$ Area $(\mathrm{m})$ & $\Delta \mathrm{A} \%$ & $|\Delta \mathrm{A} \%|$ \\
\hline $\begin{array}{l}\text { Reference } \\
\text { Normal Flow }\end{array}$ & 5 & $0.86(0.23)^{\mathrm{a}}$ & $1.76(.47)^{\mathrm{a}}$ & $3.91(0.45)^{\mathrm{a}}$ \\
$\begin{array}{l}\text { Reference } \\
\text { Post High Flow }\end{array}$ & 3 & $0.53(0.31)^{\mathrm{a}}$ & $1.05(0.61)^{\mathrm{a}}$ & $4.88(0.76)^{\mathrm{a}}$ \\
$\begin{array}{l}\text { Altered } \\
\text { Normal Flow }\end{array}$ & 5 & $0.97(0.41)^{\mathrm{a}}$ & $1.99(1.02)^{\mathrm{a}}$ & $5.18(0.94)^{\mathrm{a}}$ \\
$\begin{array}{l}\text { Altered } \\
\text { Post High Flow }\end{array}$ & 3 & $5.98(1.98)^{\mathrm{b}}$ & $12.42(4.45)^{\mathrm{b}}$ & $24.14(7.08)^{\mathrm{b}}$ \\
\hline
\end{tabular}


Figure 1. Location of the Lost River watershed and Sauerkraut Run, a first order tributary of the Lost River, Hardy County, West Virginia, USA.

Figure 2. Longitudinal profile of Sauerkraut Run showing (A) the thalweg on the entire reach surveyed; (B) the thalweg of the reference reach; and (C) the thalweg of the altered reach from 2004 through 2007.

Figure 3. Stream cross sectional profiles of the reference reach before and after high flow events on Sauerkraut Run, Hardy County, West Virginia. $\Delta \mathrm{A} \%$ is the change in percent of stream cross sectional area, $|\Delta \mathrm{A} \%|$ is the absolute value of the percent change in stream cross sectional area, $w / d_{\text {pre }}$ is the width to depth ratio before high flow, w/d diff is the difference in the width to depth ratio before and after high flow, $\mathrm{G}_{\text {pre }}, \mathrm{G}_{\mathrm{post}}$, and $\mathrm{G}_{\mathrm{diff}}$ relate to the Gini coefficient.

Figure 4. Stream cross sectional profiles of the altered reach before and after high flow events on Sauerkraut Run, Hardy County, West Virginia. Notation is defined in Figure 3.

Figure 5. Photos of Altered Reach 2 on Sauerkraut Run indicating changes in stream bed. The white dot indicates the same tree in each photo. Photo 7-5-02 showing large alluvial material; photo 4-5-03 showing removal of that material following high flow; photo 1012-03 showing deposition of gravel bed; photo 12-21-03 showing removal of gravel bed following high flow. 
Figure 6. Photos of the temporary culvert placed in Sauerkraut Run in April 2002 and removed in September 2004. Arrows indicate location of culvert, black dot indicates the same rock in the photos. Photo 7-5-02 showing area upstream of culvert prior to vegetation removal; photo 10-18-03 showing area upstream of culvert after vegetation has been removed; photo 6-18-04 showing plunge pool downstream of culvert; photo 9-26-04 showing regarded section of stream following removal of culvert with plunge pool removed. 


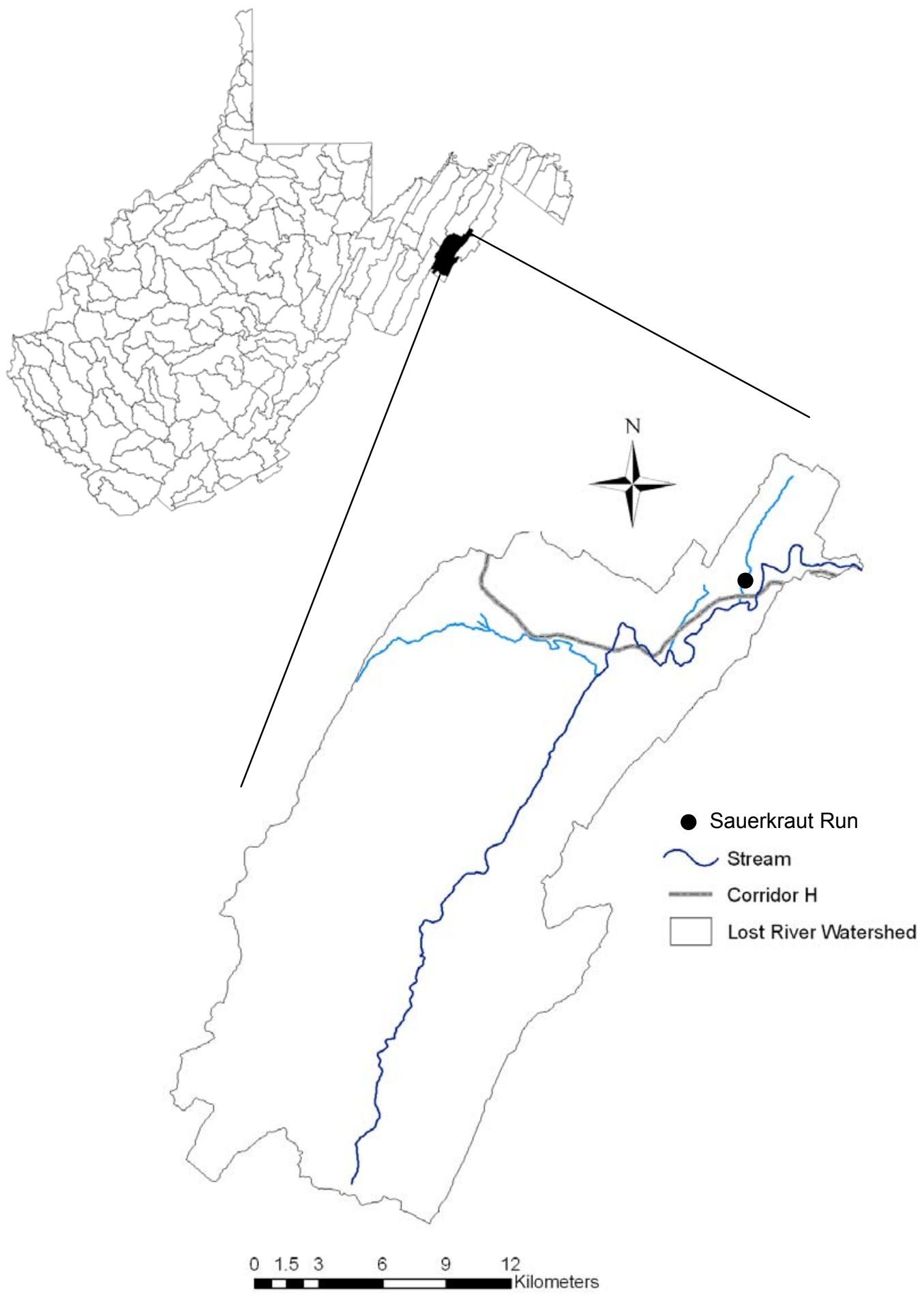


Figure 2

A

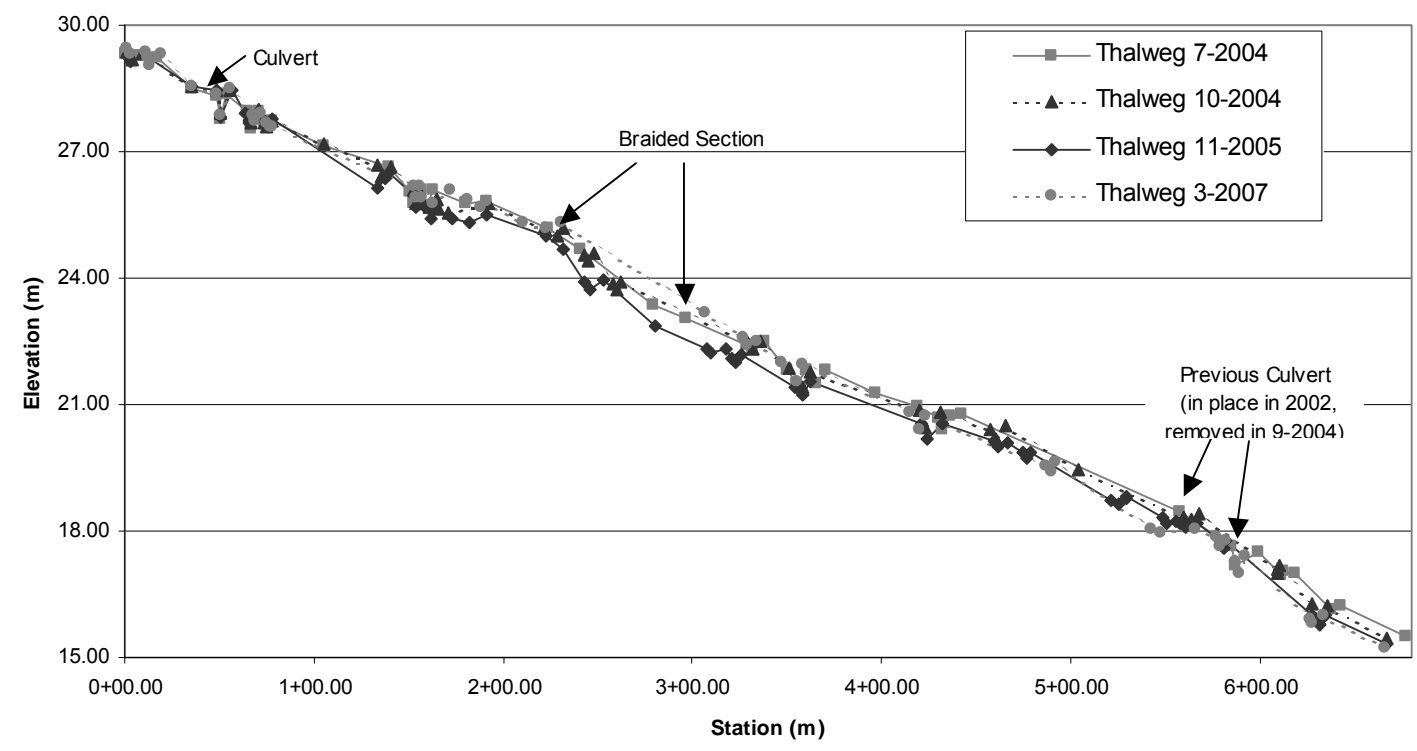

B

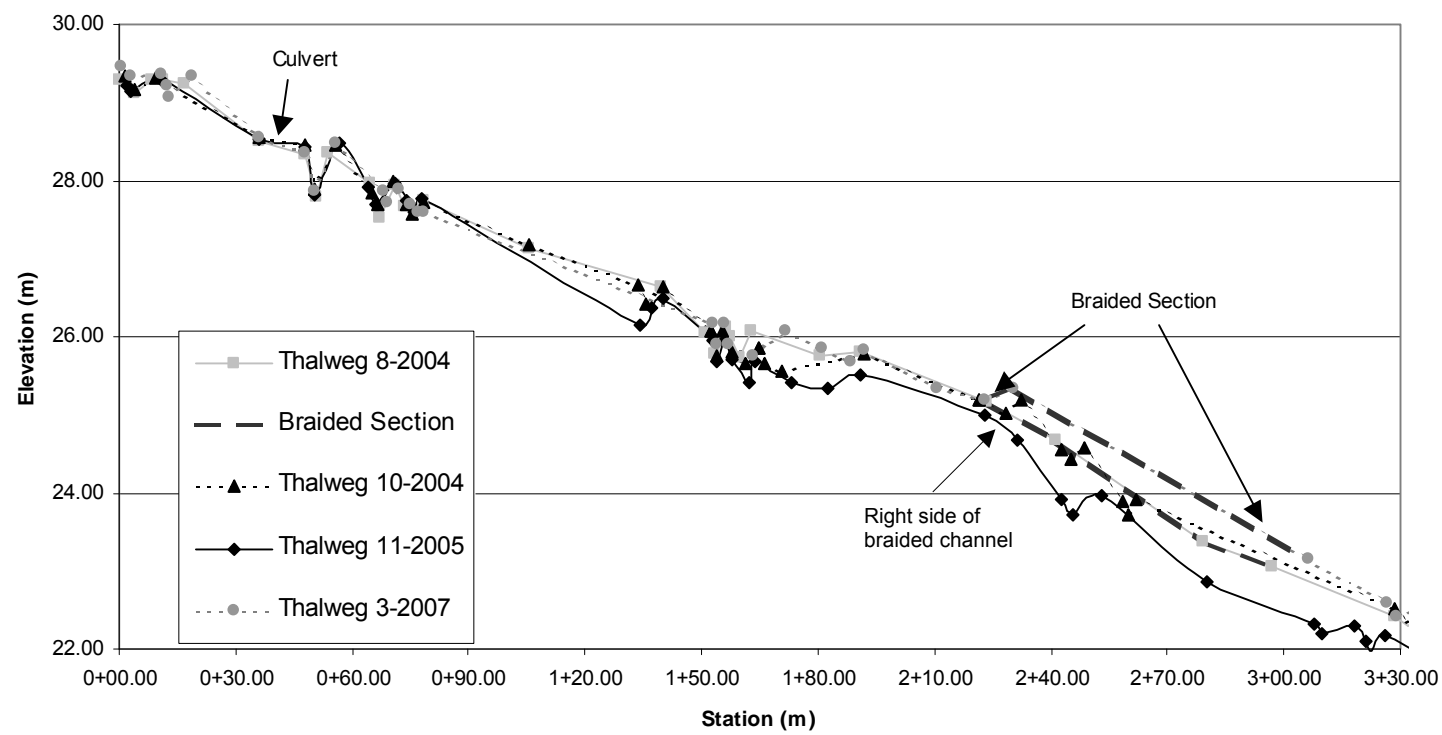

C

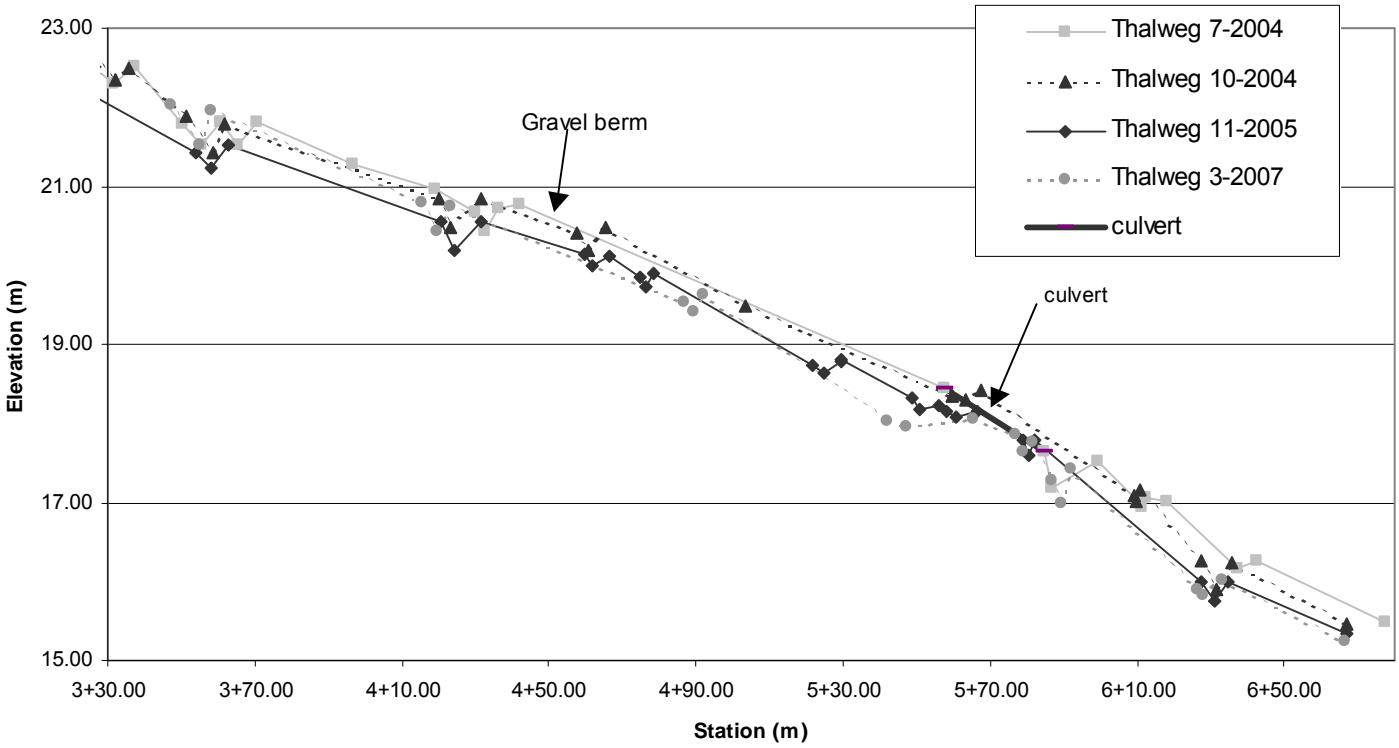


Figure 3.

\section{Reference Reach 1}

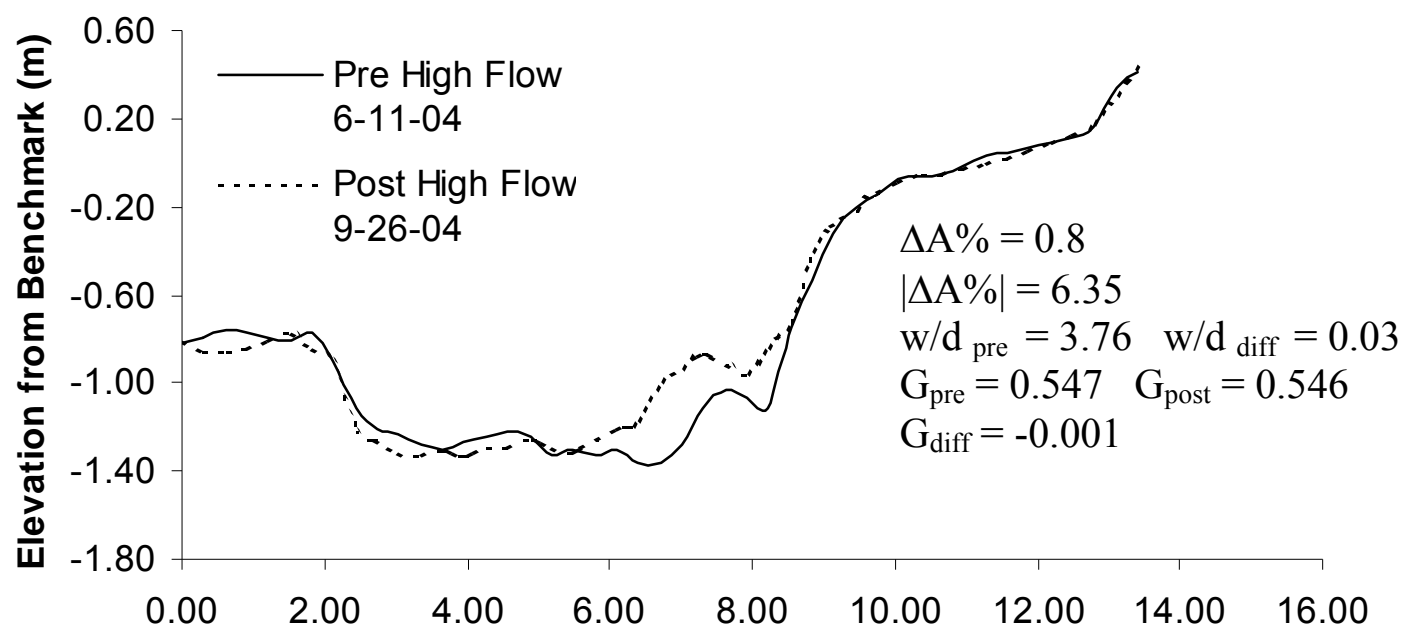

Reference Reach 2
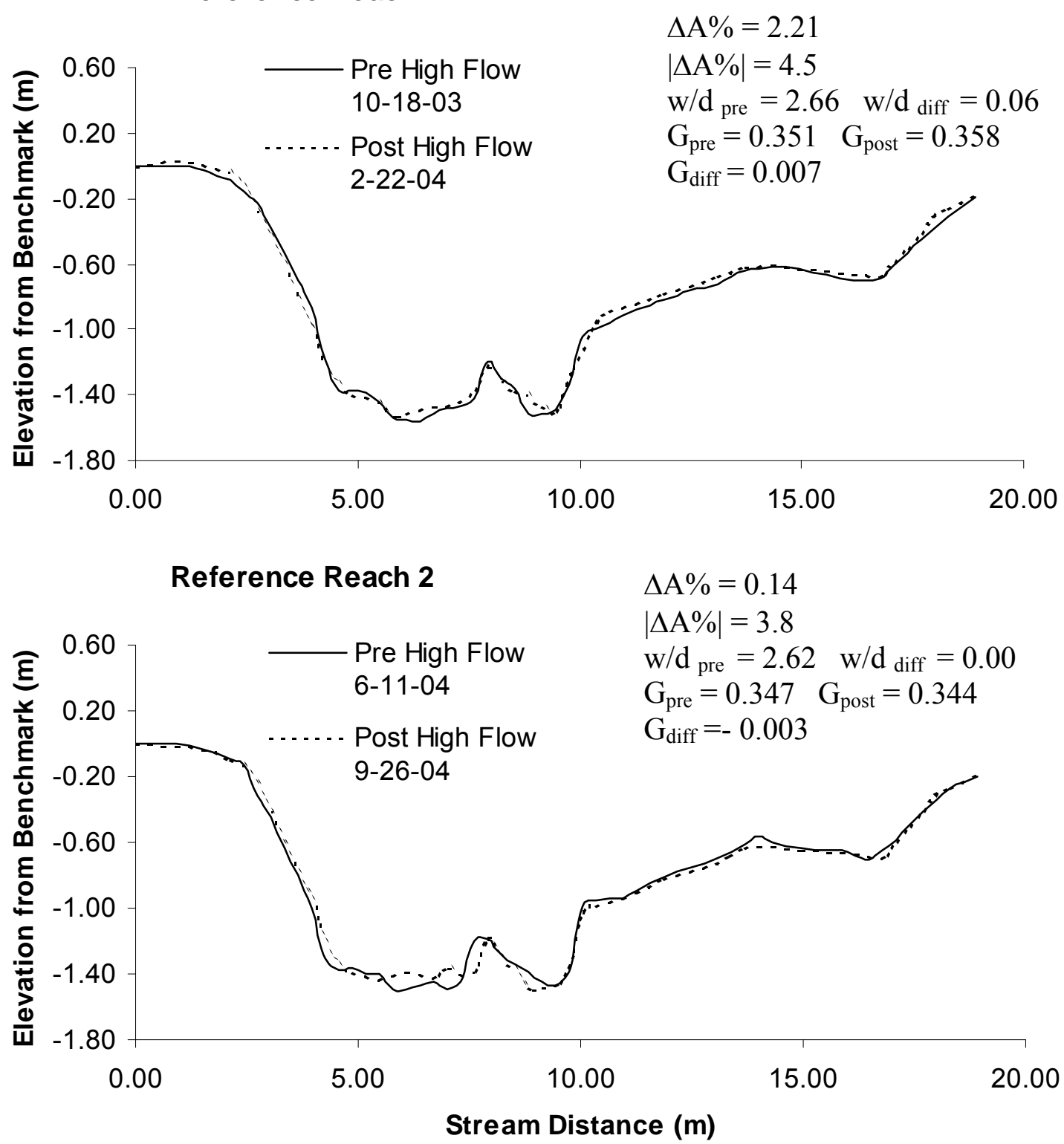
Figure 4.

Altered Reach 1

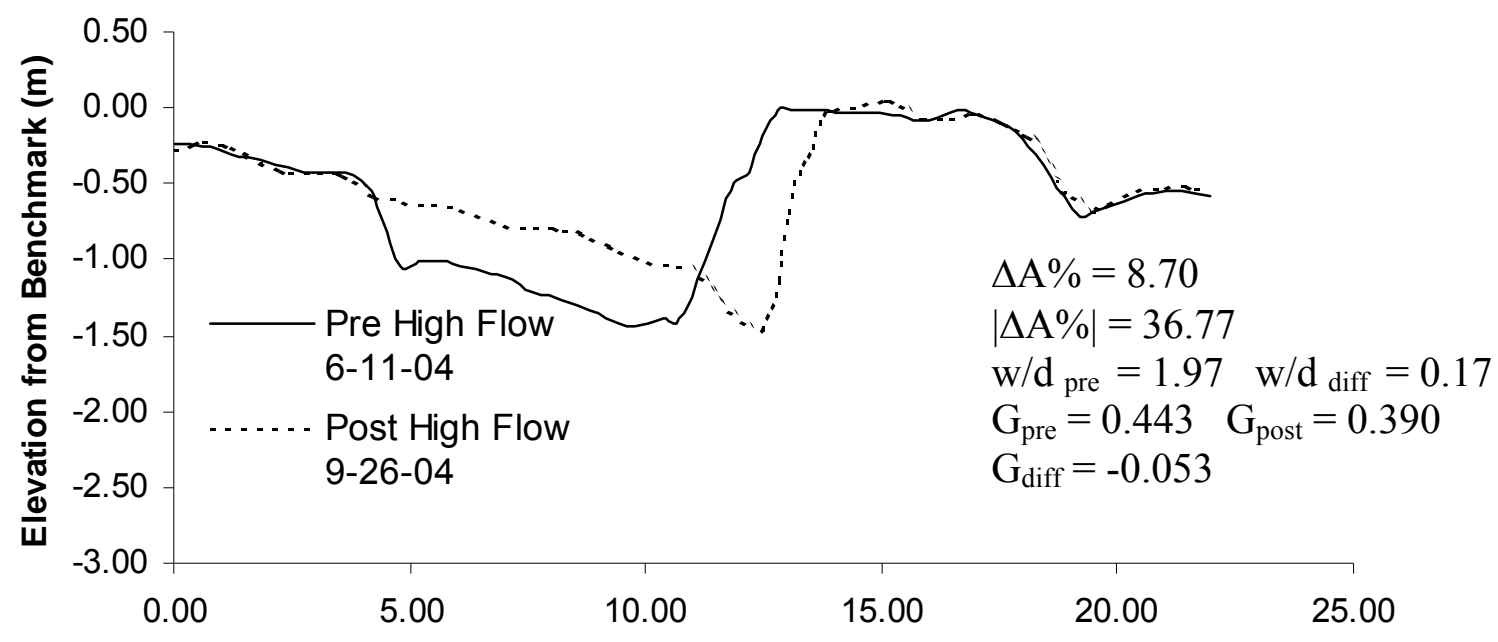

Altered Reach 2

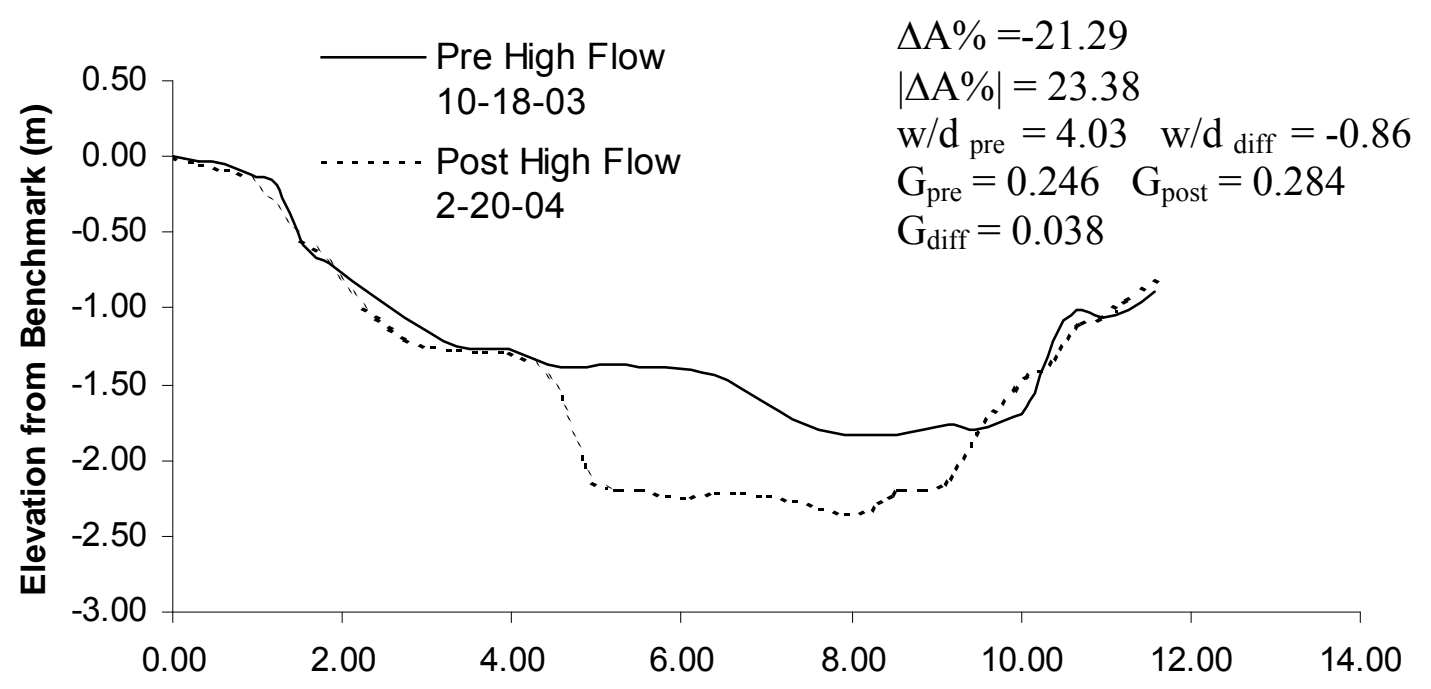

Altered Reach 2

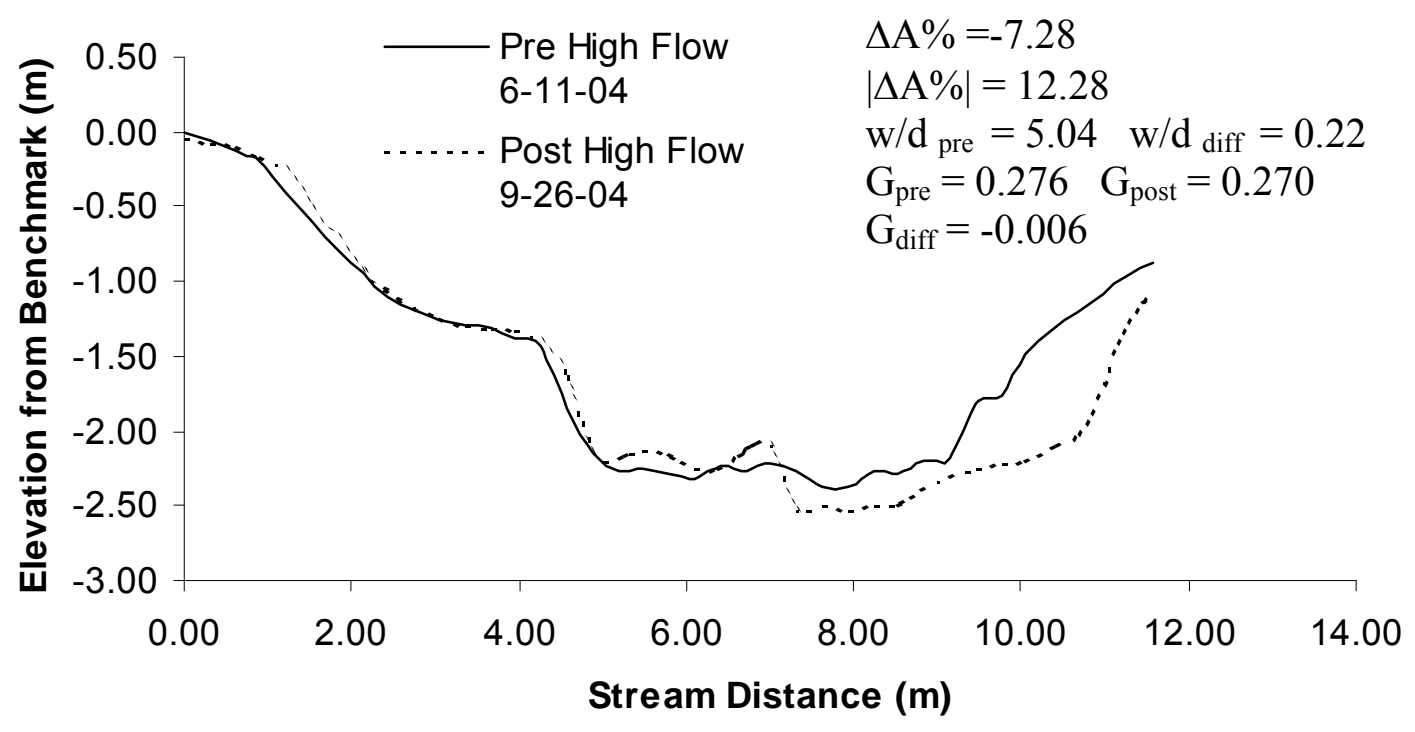


Figure 5

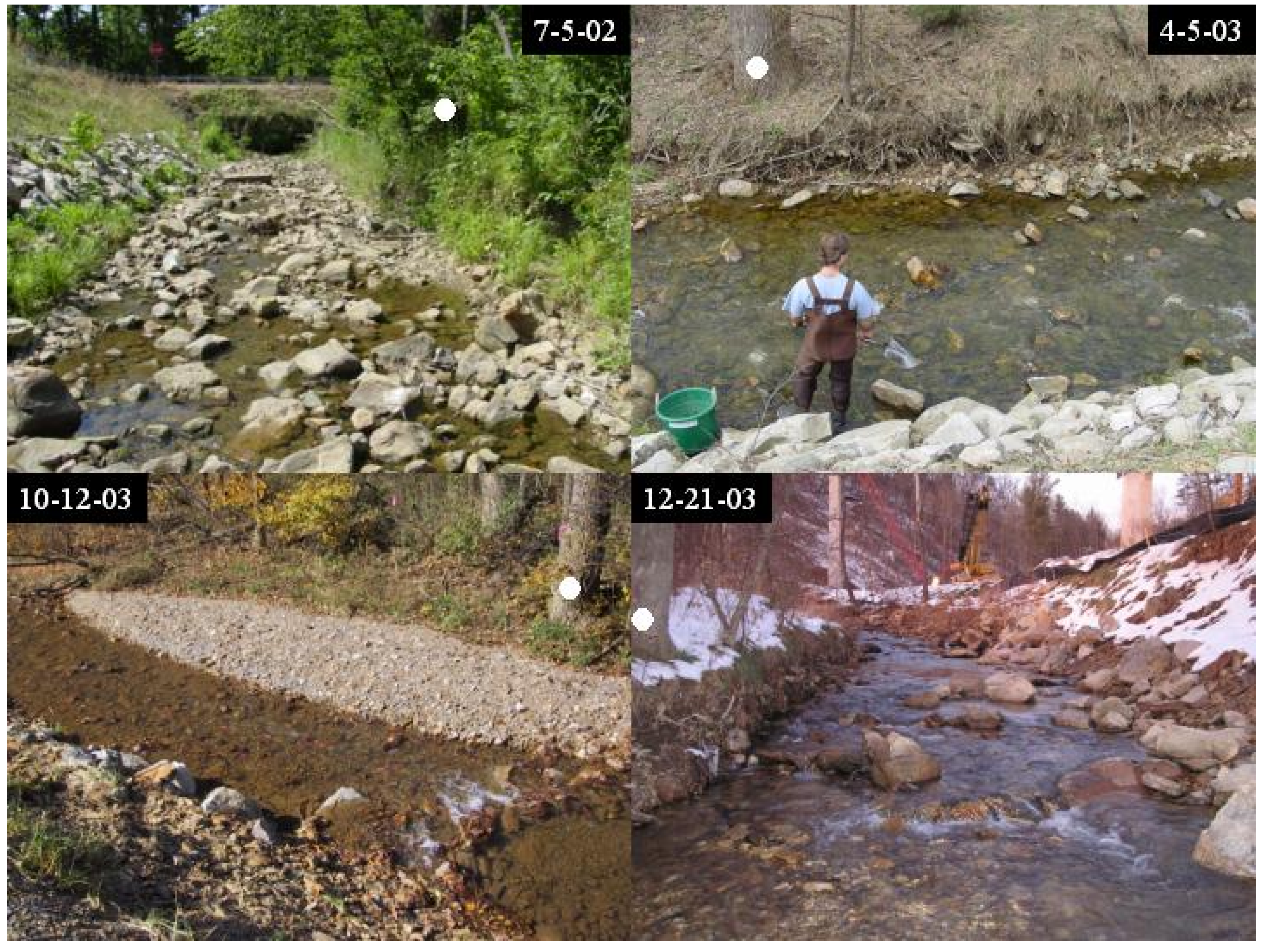




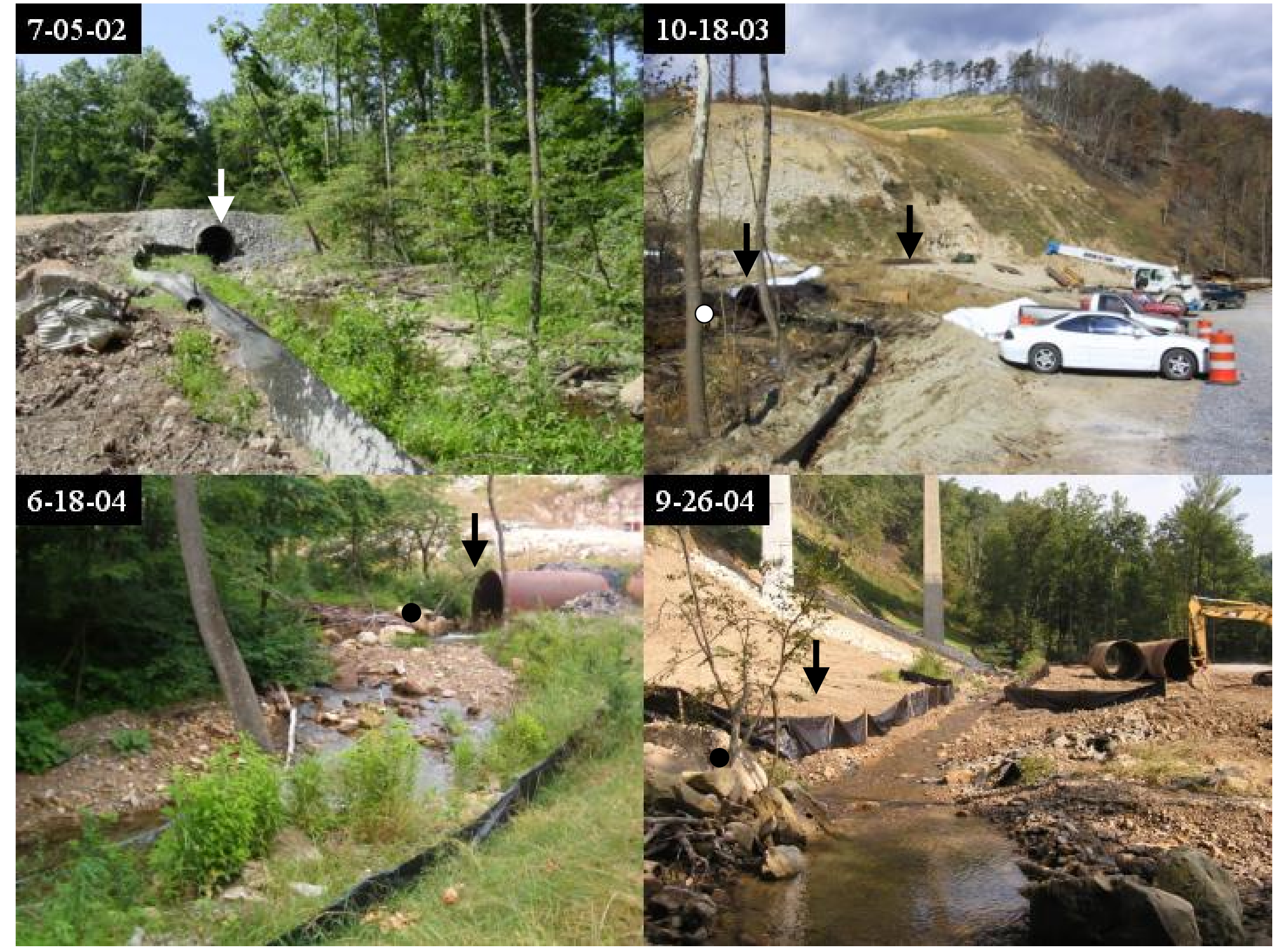


Chapter 6 - Response of benthic macroinvertebrate communities to highway construction in an Appalachian watershed 


\begin{abstract}
Highway construction in mountain area can result in sedimentation of streams, negatively impacting stream habitat and water quality. These impacts can affect the health of the biotic communities. We assessed the impacts of construction of a segment of Corridor $\mathrm{H}$, a four lane highway, in the Lost River watershed, West Virginia by monitoring benthic macroinvertebrate communities and water quality, before, during, and after highway construction at paired upstream and downstream sites from 1997 through 2007. Data analysis of temporal impacts of highway construction followed a Before-After-Control-Impact (BACI) study design. Highway construction impacts included an increase in stream sedimentation during the construction phase. This was indicated by an increase in turbidity and total suspended solids. Benthic macroinvertebrate metrics indicate a community more tolerant during, and after construction than in the period before construction. The percent of chironomidae and the Hilsenhoff Biotic Index (HBI) increased, while percent of Ephemeroptera, Plectoptera, and Trichoptera (EPT) decreased. Our 10-year study addressed short-term impacts of highway construction, and found that impacts were relatively minimal. A recovery of the number of EPT taxa collected after construction indicated that the benthic macroinvertebrate community may be recovering from impacts of highway construction. However, this study only addressed a period of three years before construction, three years during construction and four years post construction. Inferences can not be made concerning the long-term impacts of the highway, highway traffic, road runoff, and other factors associated with highway use. Continual monitoring of the watershed is necessary to determine if the highway has a continual impact on stream habitat, water quality, and biotic integrity.
\end{abstract}




\section{Introduction}

The impacts of road construction on abiotic and biotic components of stream systems have become a central focus of environmental impact studies on urban sprawl and development of rural lands (Paul and Meyer 2001, Angermeier et al. 2004). Construction-induced abiotic changes, such as an increase in sedimentation and a decrease in water quality, negatively impact biotic components, such as community composition of benthic aquatic macroinvertebrates (Barton 1977, Smith and Kaster 1983, Lamberti and Berg 1995). Although road construction impacts on streams can be short-term (Burns 1972, Cline et al. 1982, Barton 1977), a complete understanding of the impacts of road construction requires comparison of abiotic and biotic data among time periods before, during, and after the construction period (Underwood 1994).

Researchers have examined the effects of logging roads on streams in rural areas (Beschta 1978, Platts et al. 1989, Eaglin and Hubert 1993, Sugden and Woods 2007, Sheridan and Noske 2007), and on road construction and increased impervious surfaces on streams in urban areas (Wolman 1967, Hammer 1972, Booth 1990, Gregory et al. 1992, Colissimo 2007). Few studies have examined impacts of highway construction on small streams in rural areas, especially in the Appalachians (Chrisholm and Downs 1978, Cline et al. 1982). Road construction paralleling or bridging streams alters water chemistry (Helsel et al. 1979, Van Hessel et al. 1980, Wigington et al. 1983, Atkinson and Cairnes 1992, Johnson et al. 1997, Koryak et al. 2001) and stream flow (King and Tennyson 1984, Wellman et al. 2000), and increases stream sedimentation (Barton 1977, Beschta 1978, Cline et al. 1982, Eaglin and Hubert 1993, King et al. 2000). In mountainous areas of the Appalachians, roads often follow floodplain contours of stream valleys; hence, the intensity of construction impacts increases owing to the parallel proximity of roads and streams and the high number of bridge crossings. 
Road construction-induced increases of sediment in streams most commonly occur after periods of heavy rains (King and Ball 1965). Often sediment ponds or fencing do not adequately control sedimentation during heavy rain events (Barrett et al. 1995, Stevens et al. 2004, Hedrick et al. 2007). This can occur because storage capacity is inadequate, or proper overflow was not installed (Alexander et al. 1995). Highway construction creates a large amount of bare earth especially in mountainous areas where road elevation contours are maintained by mountain cuts and valley fill operations. However, unlike agriculture, which is a long-term land use, road construction projects are often short term, and site remediation can return sediment deposition and suspended solid levels back to pre-construction conditions (Barton 1977).

Stream sedimentation resulting from anthropogenic land disturbances can alter community composition and abundance of aquatic biota (Rabeni and Smale 1995; Jones et al. 1999), and decrease survival of benthic macroinvertebrates due to deposition of silt on the gills (Lemly 1982). A change in the community composition of benthic macroinvertebrates is often used as a bio-indicator of land disturbance-induced impacts on streams (Plafkin et al. 1989, Kerans and Karr 1994, Barbour et al. 1996). Benthic macroinvertebrates are useful as bioindicators of stream health because of several biological characters, such as a ubiquitous and ecologically diverse nature, a large number of taxa exhibiting a range of responses to environmental stressors (tolerant vs. intolerant taxa), and a sedentary nature (compared to fish) that allows for effective study of the extent of environmental degradation (Johnson et al. 1993). Comprehensive studies of road construction-induced environmental impacts on streams need to quantify abiotic and biotic stream conditions before, during, and after time periods of construction. A study of construction-induced impacts on streams was initiated with the planning and construction of Corridor H, a segment of the Appalachian Development Highway 
System that began in 2000 in the eastern panhandle of West Virginia. Once completed, this 158$\mathrm{km}$ segment of four-lane highway will cross 25 streams and 11 watersheds. We collected benthic macroinvertebrate, habitat, and water quality data before, during, and after construction of a section of Corridor $\mathrm{H}$ in the Lost River watershed. The objectives of this study were to determine if metric scores of benthic macroinvertebrate communities at sites upstream and downstream from construction differed prior to, during, and after road construction, and to relate changes in the benthic macroinvertebrate community to changes in water quality and habitat alteration.

\section{Study Site}

The Lost River located in Hardy County, West Virginia, has a $473-\mathrm{km}^{2}$ watershed (Figure 1), $22 \%$ of the land use is agriculture and $77 \%$ is forested land. A segment of Corridor H, a four lane highway, was constructed in the watershed between June 2000 and August 2003. We chose eight study sites along the highway alignment and sites were paired upstream and downstream of construction. Three sites were located on the main stem of the Lost River. Sites HC-1 and HC-1.5 were located downstream of construction, and site HC-2 was located upstream of construction and upstream from the confluence of Baker Run with the Lost River. Sites HC-3, HC-4, and HC-7 were located on Baker Run. Site HC-3 served as a cumulative downstream impact site, and site HC-4 was located downstream of construction and downstream of the confluence of Long Lick Run with Baker Run. Site HC-7 was located upstream of this confluence and of construction. Site HC-5 was located on Long Lick Run, upstream of construction, and site HC-6 was located on a tributary of Long Lick Run downstream of 
construction. Site HC-8 was located on a tributary of Long Lick Run that paralleled highway construction (Figure 1).

\section{Methods}

\section{Habitat}

At each site, we assessed habitat before, during and after periods of construction following the Rapid Bioassessment Protocols (RBP; Barbour et al. 1999). The RBP rates ten physical habitat parameters in three categories: epifaunal substrate/ available cover, embeddedness, velocity-depth combinations, sediment deposition, channel flow status, channel alteration, frequency of riffles, bank stability, bank vegetative protection, and riparian vegetation zone width. Habitat scores for each category range from 0 (poor) to 20 (optimal). Cumulative scores were used to evaluate habitat condition.

\section{Water Quality}

During preconstruction, water grab samples were collected every six weeks at the eight sites within the Lost River watershed. Samples were collected bi-monthly during construction, and four times a year post-construction. Water samples were collected bi-annually from Kimsey Run, a reference stream in a neighboring watershed. During collection of grab samples, water temperature $\left({ }^{\circ} \mathrm{C}\right), \mathrm{pH}$ and specific conductivity $(\mu \mathrm{s} / \mathrm{cm})$ were measured with a portable multiparameter YSI meter (Model 63, Yellow Springs Instruments, Yellow Springs, Ohio, USA), and turbidity (NTU) was measured with a portable turbidimeter (Model 2100P, HACH Company, Loveland, Colorado, USA). At each site, cross sectional flow was measured from stream-width transects with a portable flowmeter (Model 2000, Marsh-McBirney Inc., Frederick, Maryland, 
USA) following methods of Harrelson et al. (1994). In the laboratory, water samples were analyzed for total suspended solids $(\mathrm{mg} / \mathrm{L})$, iron $(\mathrm{mg} / \mathrm{L})$, calcium $\left(\mathrm{mg} / \mathrm{L}\right.$ as $\left.\mathrm{CaCO}_{3}\right)$, sulfate

$(\mathrm{mg} / \mathrm{L})$, chloride $(\mathrm{mg} / \mathrm{L})$, alkalinity $\left(\mathrm{mg} / \mathrm{L}\right.$ as $\left.\mathrm{CaCO}_{3}\right)$, acidity $\left(\mathrm{mg} / \mathrm{L}\right.$ as $\left.\mathrm{CaCO}_{3}\right)$, nitrate $(\mathrm{mg} / \mathrm{L})$, ammonia (mg/L) and phosphate (mg/L; APHA 1998).

\section{Benthic Macroinvertebrates}

We collected benthic macroinvertebrate samples every six weeks using a modified version of the single habitat protocol described by Barbour et al. (1999). A $500 \mu$ net with a $50 \times 30 \mathrm{~cm}$ sampling frame was placed in the streambed, and invertebrates were sampled from a $0.25-\mathrm{m}^{2}$ area of riffle immediately upstream of the net. Surfaces of large rocks were rubbed to dislodge invertebrates, and the substrate was disturbed to a maximum depth of four centimeters. We composited four $0.25 \mathrm{~m}^{2}$ samples to obtain a $1-\mathrm{m}^{2}$ sample for each site. In the laboratory, samples were sub-sampled symmetrically, and macroinvertebrates were enumerated and identified according to Peckarsky (1990), Merritt and Cummins (1996), and Wiggins (1996).

We counted the number of EPT (Ephemeroptera, Plecoptera, Trichoptera) taxa and total taxa, and calculated the percent of EPT, the percent of chironomidae, percent of the top two dominant taxa, and the modified Hilsenhoff Family Biotic Index (HBI; Hilsenhoff 1998). The modified HBI classifies individual taxa based on their tolerance or intolerance of various levels of pollution. The score is ranked from 0 to 10 with 10 being considered "very poor" and 0 being considered "excellent". 


\section{Study Design}

Our analysis of temporal impacts of highway construction followed a Before-AfterControl-Impact (BACI) study design (Underwood 1994). Paired sites were selected based on habitat similarity, and were located on the same stream and same or next stream order. Paired sites were located upstream (three sites) and downstream (five sites) of highway construction.

We collected benthic macroinvertebrate data during three time periods: three years before construction $(n=3)$, three years during construction $(n=5)$, and four years after construction $(n=8)$. Water quality data were also collected during the three construction time periods (before $\mathrm{n}=30$; during $\mathrm{n}=20$; after $\mathrm{n}=20$ ). Using data from multiple pairs of sites allowed for spatial replication within the watershed and addressed a common concern of pseudo-replication in simple BACI designs (Stewart-Oaten et al. 1986, Underwood 1994, Stewart-Oaten and Bence 2001).

\section{Analysis}

We tested the data for normality using the Shapiro-Wilks test (Sokal and Rohlf 1995), and for homogeneity of variances using the Levene test (Levene 1960, SAS Institute Inc., 1999, Montgomery 2004). We analyzed the benthic data using a mixed-model methodology for repeated measures, analysis of variance (ANOVA) and analysis of covariance (ANCOVA; Littell et al. 1996). Data for each metric were used to estimate several covariance structures (unstructured, compound symmetry, and autoregressive) using the SAS PROC MIXED procedure (Littell et al. 1996), and the appropriate covariance structure was selected with the second order adjustment of Akaike's information criterion (AICc). Construction time period (before, during, or after) and site type (upstream or downstream) were included in the mixed model as fixed effects, and repeated measures were taken on the experimental unit (i.e., site 
nested within type). After selection of covariance structure, we estimated the least-square means for each metric for each site type and construction time period. Using the appropriate model for covariance structure, we used ANCOVA to examine the effects of construction time period, site type, and construction time period $\mathrm{x}$ site type interactions on each metric. Each water quality variable was used as covariate in separate statistical models. The significance level of $\alpha=0.05$ was adjusted to $\alpha=0.0036$ using the Bonferroni correction (Johnson 1998). Analyses were conducted using SAS (SAS Institute Inc, 1999).

\section{Results}

The habitat scores were similar among sites $(\mathrm{p}>0.05)$, with all sites having optimal to sub-optimal epifaunal substrate and levels of embeddedness (less than $50 \%$ of gravel, cobble and boulder surrounded by fine sediment). Velocity/depth combinations varied, most sites had at least 3 of the combinations of slow-deep, slow shallow, fast-deep, and fast-shallow. Sites had adequate riparian zones and channel alteration was minimal. Little changes occurred during the construction phase at our monitoring sites. Most were located outside of construction zones and were not impacted by removal of streamside vegetation, or channelization. One site, HC-4, located downstream of a current county road bridge did undergo streambed change when a high flow event in September 2003 scoured the larger cobble alluvial material creating a gravel bar downstream and leaving the site dominated by coarse and fine gravel. Habitat variables were not used as covariates in our model since monitoring sites did not differ among or between site type or construction period.

Road construction influenced two water quality variables associated with sedimentation, Turbidity and TSS, as well as several other water quality variables. Turbidity and TSS were 
greater at downstream sites during the construction phase, and did not remain high following construction (Figure 2). Several other water quality parameters, including alkalinity, conductivity, sulfates, and calcium, were consistently higher at downstream sites (Figure 2). There was an increase in ammonia and iron during construction at the downstream site. Although some water quality variables were elevated at the downstream sites, they were not above the recommended ranges for aquatic life (Table 1). Chloride was reported higher than the recommended $11 \mathrm{mg} / 1$ (US EPA 1986) on several sampling dates (Figure 2), but not on average, or during the highway construction phase. We did not analyze the instantaneous measures of flow or use these flow data as a covariate in analysis. Instantaneous measurements of flow do not likely reflect elevation of water quality constituents that result from previous flow conditions. Mountain streams can be flashy with quick rises and falls in stage height (Johnes 2007), but we did not capture flow data during storm events.

For all analyses, data met assumptions of normality and homogeneity of variance. The best approximation of covariance structure for all metrics was the first order autoregressive (AR) model. This covariance structure suggests higher correlations between proximate times than for distant times (Littell et al. 1996). At the downstream sites, a significant construction time period effect $(\mathrm{p}<0.05)$ occurred for all metrics except the total number of taxa. The percent top 2 dominant taxa was significantly higher before construction (Table 2; Figure 3), and percent chironomidae was significantly higher after construction (Table 2; Figure 3). The percent of EPT decreased after construction, and the number of EPT taxa decreased during construction (Table 2; Figure 3). The HBI increased during construction and remained higher following construction, indicating that the biotic integrity of the community change from "excellent" $(0.00-$ $3.75)$ to "good" (4.25 to 5.00). 
There was no significant site type effect, however, there was a construction time period $\mathrm{x}$ site type effect for $\%$ chironomidae, EPT taxa, and HBI $(\mathrm{p}<0.05)$. For these three metrics, upstream sites scored poorer than downstream sites before construction. After construction, downstream sites scored poorer, with a higher percentage of chironomidae (a tolerant taxa), a higher HBI score, and a lower percentage of EPT taxa (Figure 2).

A significant covariate effect for turbidity, conductivity, total suspended solids (TSS), iron, sulfate, chloride, $\mathrm{pH}$, alkalinity, nitrate, ammonia, and phosphate $(\mathrm{p} \leq 0.0036)$ was detected at the downstream sites for HBI. Turbidity and TSS had a siginificant covariate effect on the number of EPT taxa, and percent of EPT ( $\mathrm{p} \leq 0.0036)$. There was no significant covariate effect on benthic macroinvetebrate metrics \% EPT, \% chironomidae, \% of the top two dominant taxa, and HBI at the upstream sites. Covariate effect on the number of EPT taxa at the upstream site for variables turbidity, $\mathrm{pH}$, conductivity, total suspended solids (TSS), calcium, sulfate, chloride, alkalinity, acidity, nitrate, ammonia, and phosphate was significant $(\mathrm{p} \leq 0.0036)$. Conductivity, TSS, acidity, calcium, sulfate, and ammonia had a significant $(\mathrm{p} \leq 0.0036)$ covariate effect on total number of taxa.

\section{Discussion}

Two water quality variables, turbidity and TSS, are directly associated with stream sedimentation and increased during construction of sites within the Lost River watershed. Mean values of turbidity and TSS are only reported for spring and fall (Figure 2), corresponding to our benthic macroinvertebrate sampling seasons. However, plots across all seasons indicate two additional spikes in turbidity and TSS during the construction phase in 2000 and 2001. An increase in turbidity, TSS, and stream sedimentation was expected given similar findings from 
previous studies (Burton et al. 1976, Barton 1977, Cline et al. 1982, Embler and Fletcher 1983, Downs and Appel 1986). Sedimentation and run off is an environmental concern at highway construction sites (US EPA 1990). Factors that affect sedimentation from construction projects include rainfall, road slope, drainage management, and the erodibility of the source area (such as cut-and-fill slope characteristics, and the degree of surfacing), and the amount of construction traffic (Sheridan and Noske 2007). We noticed spikes in turbidity and TSS during the construction phase instead of gradual change. Sedimentation was related to rainfall events, indicating that during much of the construction phase, management practices such as silt fencing and sediment ponds were adequate to control sedimentation.

Before the construction phase, several water quality variables including conductivity, alkalinity, iron, sulfates, and calcium were higher at the downstream sites versus the upstream sites. Our study paired sites in similar habitat and within similar stream order. However, the Lost River watershed is influenced by other human impacts. Although $22 \%$ of the watershed is in agriculture use, due to the alignment of the highway, our sites had a higher percentage of agriculture land use in a 30-m buffer zone along a 150-m stream reach (Hedrick, unpublished data). Sites varied from $50 \%$ to $100 \%$ agriculture riparian use. Watersheds and streams influenced by agriculture land use tend to have higher levels of nutrients, such a nitrogen and phosphorous (Crawford and Lenat 1989, Roth et al. 1999). Additionally, many "downstream" monitoring sites were located near, or crossed by, rural and county maintained roads. Site HC1.5 was downstream of construction, but also downstream of a current gravel road and bridge. Site HC-3 was downstream of a bridge crossing for State Route 55, and HC-4 was downstream of a rural bridge crossing over Baker Run. These sites were influenced by roads prior to construction of the highway. Conductivity is a measure of the amount of total dissolved solids or 
salts (TDS). Higher conductivity values at downstream sites can be related to influences from current roads, including inputs of de-icing salts, and influences from agriculture. Water draining agriculture fields typically has high levels of dissolved salts (US EPA 2006). Although differences existed between sites prior to construction, they did not impact our ability to detect changes related to construction at the downstream sites.

Additionally, chemical parameters were similar to other studies involving effects of road construction on water quality (Harned 1988, Barrett et al. 1995). Little change was noticed in most chemical water quality parameters upstream and downstream of construction. In a study of paired sites located in Danz Creek watershed, Travis County, Texas upstream and downstream of a Texas Department of Transportation project, Barrett et al. (1995) noticed a spike in iron during construction. The iron concentration was related to the concentration of suspended solids. A similar relation occurred for water samples from sites in the Lost River watershed in Fall 2002 (Figure 2).

Cleveland and Fashokunz (2006) monitored a pair of sites upstream and downstream of a temporary sediment control structure before, during and after highway construction in Harris County, Texas. Of the water quality parameters measured, only TSS and phosphates were significantly greater during construction times periods. The concentration of TSS was two times greater during non-storm flow events and six to ten times greater during stormwater events. After construction, TSS and phosphorous were similar to during construction values. Elevated nitrogen and phosphorous can result from run-off of fertilizer during and following site restoration (US EPA 2005)

Spikes in ammonia during Spring 2002 and Fall 2004 were related to high flow events due to heavy rains. During the first week of September 2004, heavy rains and high flows 
resulted from the effects of Hurricane Frances (Southeast Regional Climate Center, www.sercc.com). An increase in runoff from agricultural land, especially land with livestock and manure fertilizer, could influence ammonia levels in the water (US EPA 2006). We did not measure flow during and directly after these storm events, however, data from a local USGS stream gage located in the watershed indicate high flows. The maximum flow in Fall 2004 was $249 \mathrm{cfs}$, with an average flow of $12.1 \mathrm{cfs}$.

In Fall 2005, several water quality variables increased at the downstream sites, including conductivity, alkalinity, acidity, sulfates and chlorides. During Fall 2005, low amounts of precipitation resulted in low stream flows. Lack of flow and ability of the stream to dilute various chemicals (Johnes 2007) may have caused the elevated values. None of the water quality parameters tested in our study reached levels that limit aquatic fauna of streams.

Changes of some benthic macroinvertebrate metrics indicated construction effects on benthic macroinvertebrate communities at downstream sites. The percent of EPT taxa decreased over time, and the HBI and percent of chironomidae increased over time, indicating a more tolerant benthic macroinvertebrate community. This shift from intolerant to tolerant taxa is consistent with the results of other stream/land disturbance studies (Chrisholm and Downs 1978, Stepenuck et al. 2002, Wang and Kanehl 2003, Gage et al. 2004, Riley et al. 2005). In warm water streams in Wisconsin, levels of watershed urbanization were negatively correlated to EPT abundance and positively correlated to HBI (Stepenuck et al. 2002). In a study of urbanization impacts on coldwater streams, Wang and Kanehl (2003) also found an increase in HBI scores and a decrease in EPT abundance.

The number of total taxa was not significantly different at upstream and downstream sites or among time periods. Collecting similar number of taxa does not indicate similarity in the 
benthic macroinvertebrate communities among sites and time periods. The number of taxa can be similar, however, the tolerance of the taxa can differ among sites. In a study to document the effects of constructing a highway across Halon Creek, a small stream in Ontario, Barton (1977) found no appreciable differences in the total number of benthic macroinvertebrates although species composition changed. There was an increase in tolerant taxa and a decrease in sensitive taxa.

Although we documented a decrease in percent EPT and an increase in percent chironomidae, a post-construction increase in number of EPT taxa indicates partial recovery of the benthic macroinvertebrate population. In a study on another stream in the Lost River watershed, Hedrick et al. (2007) found that complete removal of the streambed, (i.e., degradation of 3-ft of bed material), did not have a long-term effect on the benthic macroinvertebrate community. In a study of highway culvert construction and riffle habitat restoration within a small stream in Ontario, Barton (1977) reported recovery of macroinvertebrate species composition and abundance within a year after streambed restoration. Cline et al. (1982) found that within one year post-construction, IBI values were comparable to reference sites on a high elevation Rocky Mountain stream. Repopulation and diversification of macroinvertebrate communities occurred quickly in disturbed and newly-created reaches of Turtle Creek, West Virginia (Chrisholm and Downs 1978). Within about one year, the benthic macroinvertebrate population of the disturbed stream was similar to that of the control stream (Chrisholm and Downs 1978). Tributary inflow and downstream drift of benthic macroinvertebrates from unaltered stream reaches contribute to successful recovery of benthic macroinvertebrate communities within disturbed stream reaches (Williams and Hynes 1976, Gray and Fisher 1981). 
Highway construction influenced water quality and benthic macroinvertebrates within the 10-year study period, but the magnitude of impact was minimal during our short-term study. During construction, the benthic macroinvertebrate communities declined in biotic integrity, but were still classified as "good" by HBI scores. Our study, however, examined short-term effects of highway construction, but long-term effects should also be considered (Angermeier et al. 2004). Further studies on long-term effects should include a focus on road runoff, such as deicing salts (Koryak et al. 2001) and elevated stream water temperatures (Roth et al. 1999). The stretch of Corridor $\mathrm{H}$ through the Lost River watershed is located in a rural setting, and impacts will likely increase with time as land use shifts gradually from rural to urban. Smith and Kaster (1983) found that runoff from roadways with light traffic density (7,000-8,000 vehicles per day) had only a minimal effect on macroinvertebrate populations. Our short-term study does not allow inference toward the long-term continual health of study streams, and long-term studies should monitor the increase in urbanization and its impacts on streams within the watershed.

\section{Acknowledgements}

We would like to thanks the West Virginia Division of Highways for providing partial support for this research. Jim Hedrick and Will Ravencroft were helpful in collecting data, and Brandon Keplinger and Seth Lemly identified benthic macoinvertenrate samples in the lab. Reference to trade names does not imply endorsement of commercial products by the U. S. government. 


\section{Literature Cited}

Alexander, J. L., R. A., Clay, and J. F. Ott. 1995. Protecting Water Quality: A field guide to erosion, sediment and stormwater best management practices for development sites in Missouri and Kansas. The St. Charles County Soil \& Water Conservation District, St. Charles, Missouri, \& the Dam and Reservoir Safety Program, Division of Geology and Land Survey, Missouri Department of Natural Resources, Rolla, Missouri.

American Public Health Association (APHA). 1998. Standard Methods for the Examination of Water and Wastewater, $20^{\text {th }}$ ed. Clersceri, L. S., Greenber, A. E., and Easton, A. D. (ed.), American Public Health Association, Washington, D.C.

Angermeier, P. L., A. P. Wheeler, and A. E. Rosenberger. 1994. A conceptual framework for assessing impacts of roads on aquatic biota. Fisheries 29:19-29.

Atkinson, R. B., and J. Cairns, Jr. 1992. Ecological risk of highways. Pages 237-262 in J. Cairns, Jr., B. R. Niederlehner, and D. R. Orvos, eds. Predicting ecosystem risk. Princeton Scientific, Princeton, New Jersey.

Barbour, M. T., J. Gerritsen, R. G. E. Griffith, R. Frydenborg, E. McCarron, J. S. White, and M. L. Bastian. 1996. A framework for biological criteria for Florida streams using benthic macroinvertebrates. Journal of the North American Benthological Society 15:185-211.

Barbour, M.T., J. Gerritsen, B.D. Snyder, and J.B. Stribling. 1999. Rapid Bioassessment

Protocols for Use in Streams and Wadeable Rivers: Periphyton, Benthic Macroinvertebrates and Fish, Second Edition. EPA 841-B-99-002. U.S. Environmental Protection Agency; Office of Water; Washington, D.C. 
Barrett, M. E., J. F. Malina, Jr., R. J. Charbeneau, and G. H. Ward. 1995. Effects of highway construction and operation on water quality and quantity in an ephemeral stream in the Austin, Texas area. Technical Report CRWR 262. Center for Research in Water Resources, Austin, Texas.

Barrett, M. E., J. E. Kearney, T. G. McCoy, J. F. Malina, R. J. Charbeneau, and G. H. Ward. 1995. An evaluation of the use and effectiveness of temporary sediment controls. Technical Report CRWR 261, Center for Research in Water Resources, The University of Texas at Austin, Austin, Texas.

Barton, B. A. 1977. Short-term effects of highway construction on the limnology of a small stream in southern Ontario. Freshwater Biology 7: 99-108.

Beschta, R. L. 1978. Long-term patterns of sediment production following road construction and logging in the Oregon coast range. Water Resources Research 14:1011-1016.

Booth, D. B. 1990. Stream-channel incision following drainage-basin urbanization. Water Resources Bulletin 26: 407-417.

Burns, J. W. 1972. Some effects of logging and associated road construction on Northern California streams. Transactions of the American Fisheries Society 101: 1-16.

Burton, T.M., R. R. Turner, and R. C. Harris. 1976. The impact of highway construction on a North Florida Watershed. Water Resources Bulletin 12:529-538.

Chirsholm, J. L., and S. C. Downs. 1978. Stress and recovery of aquatic organisms as related to highway construction along Turtle Creek, Boone County, West Virginia. U.S. Geological Survey Water Supply Paper 2055, Washington, DC. 
Cleveland, T. G., and A. Fashokunz. 2006. Construction-associated solid loads with a temporary sediment control BMP. Journal of Construction Engineering and Management 132:1122-1125.

Cline, L. D., R. A. Short, and J. V. Ward. 1982. The influence of highway construction on the macroinvertebrate and epilithic algae of a high mountain stream. Hydrobiologia 96:149159.

Colosimo, M. F., and P. R. Wilcock. 2007. Alluvial sedimentation and erosion in an urbanizing watershed, Gwynns Falls, Maryland. Journal of the American Water Resources 43: 499521.

Crawford, J. K., and D. R. Lenat. 1989. Effects of lan use on the water quality and biota of three streams in the Piedmont province of North Carolina. U. S. Geological Survey. Water Resources Investigation Report 89-4007. Raleigh, North Carolina.

Downs, S.C., and D. H. Appel. 1986. Progress report on the effects of highway construction on suspended-sediment discharge in the Coal River and Trace Fork, West Virginia 1975-81. USGS Water-Resources Investigations Report 84-4275.

Eaglin, G. S., and W. A. Hubert. 1993. Effects of logging and roads on substrate and trout in streams of the Medicine Bow National Forest, Wyoming. North American Journal of Fisheries Management 13:844-846.

Embler, P.F., and M. O. Fletcher. 1983. Effects of highway construction on stream turbidity and suspended solids: A case study. FHWA/SC-81/3. Federal Highway Administration, Washington, D.C. 
Gage, M. S., A. Spivaki, and C. J. Paradise. 2004. Effects of land use and disturbance on benthic insects in headwater streams draining small watersheds north of Charlotte, NC. Southeastern Naturalist 3:345-358

Gray, L. J., and S. G. Fisher. 1981. Postflood recolonization of macroinvertebrates in a lowland sonoran desert stream. American Midland Naturalist 106:249-257.

Gregory, K. J., R. J. Davis, and P. W. Downs. 1992. Identification of river channel change due to urbanization. Applied Geography 12:299-318.

Hammer, T.R. 1972. Stream channel enlargement due to urbanization. Water Resources Research 8: 1530-1540.

Harned, D.A. 1988. Effects of highway runoff on streamflow and water quality in the Sevenmile Creek Basin, a rural area in the piedmont province of North Carolina, July1981 to July 1982. USGS Water Supply Paper 2329.

Harrelson, C. C., C. L. Rawlins, and J. P. Potyondy. 1994. Stream channel reference sites: an illustrated guide to field techniques. Gen. Tech. Rep. RM-245. U. S. Department of Agriculture, Forest Service, Rocky Mountain Forest and Range Experiment Station. Fort Collins, Colorado.

Hartman, K. J., and J. P. Hakala. 2006. Relationships between fine sediment and brook trout recruitment in forested headwater streams. Journal of Freshwater Ecology 21:215-230.

Hedrick, L.B., S.A. Welsh, and J.D. Hedrick. 2005. A new sampler design for measuring sedimentation in streams. North American Journal of Fisheries Management 25:238-244.

Hedrick, L.B., S. A. Welsh, and J. T. Anderson. 2007. Effects of highway construction on sediment and benthic macroinvertebrates in two tributaries of the Lost River, West Virginia. Journal of Freshwater Ecology 22:561-569. 
Helsel, D. R., J. I. Kim, T. J. Gizzard, C. W. Randall, and R. C. Hoehn. 1979. Land use influences on metals in storm drainage. Journal of the Water Pollution Control Federation 51:709-717.

Hilsenhoff, W.I. 1998. A modification of the biotic index of organic stream pollution to remedy problems and to permit its use throughout the year. The Great Lakes Entomologist. 31:112.

Jenkins, M., E. Wade, J. Fletcher, and J. Hankins. 1995. "Economic Analysis of NonTraditional Water Resources for Aquaculture in West Virginia.” Technical Report funded in part by Appalachian Regional Commission, West Virginia University, Morgantown, West Virginia.

Johnes, P.J. 2007. Uncertainties in annual riverine phosphorus load estimation: Impact of load estimation methodology, sampling frequency, baseflow index and catchment population density. Journal of Hydrology 332:241- 258.

Johnson, D. E. 1998. Applied Multivariate Methods for Data Analysis. Brooks/Cole Publishing Company, Pacific Grove, California.

Johnson, L. B., C. Richards, G. Host, and J. W. Arthur. 1997. Landscape influences on water chemistry in Midwestern stream ecosystems. Freshwater Biology 37:193-208.

Johnson, R. K., T. Wilderholm, and D. M. Rosenberg. 1993. Freshwater biomonitoring using individual organisms, population, and specied assemblages of benthic macroinvertebrates. Pages 40-158 in D. M. Rosenberg and V. H. Resh, eds., Freshwater Biomontioring and Benthic Macroinvertebrates. Chapman Hall, New York, New York. 
Jones, E. B.D. III, G. S. Helfman, J. O. Harper, and P. V. Bolstad. 1999. Effects of riparian forest removal on fish assemblages in southern Appalachia streams. Conservation Biology 13:1454-1465.

Kerans, B. L., and J. R. Karr. 1994. A benthic index of biotic integrity (B-IBI) for rivers of the Tennessee Valley. Ecological Applications 4:768-785.

King, D. L., and R. C. Ball. 1965. The influence of highway construction on a stream. Michigan State University, Agriculture Experiment Station, East Lansing. Research Report No. 19:

King, J. G., and L. C. Tennyson. 1984. Alteration of streamflow characteristics following road construction in north central Idaho. Water Resources Research 20:1159-1163.

King, R. R., K. T. Nunnery, and C. J. Richardson. 2000. Macroinvertebrate assemblage response to highway crossings in forested wetlands: implications for biological assessment. 2000. Wetlands Ecology and Management 8:243-256.

Koryak, M., L. J. Stafford, R. J. Reilly, and P. M. Magnuson. 2001. Highway deicing salt runoff events and major ion concentrations along a small urban stream. Journal of Freshwater Ecology 16:125-134.

Lamberti, G. A., and M. B. Berg. 1995. Invertebrates and other benthic features as indicators of environmental change in Juday Creek, Indiana. Natural Areas Journal 15:249-258.

Levene, H. 1960. Robust tests for equality of variances. Pages 278-292 in I. Olkin,, S.G. Ghurye, W. Hoeffding, W.G. Madow and H.B. Mann, eds. Contributions to probability and statistics. Stanford University Press, Stanford, California.

Lemly, D. A. 1982. Modification of benthic insect communities in polluted streams: combined effects of sedimentation and nutrient enrichment. Hydrobiologia 87:229-245. 
Littell, R. C., G. A. Miliken, W. W. Stroup, and R. D. Wolfinger. 1996. SAS system for mixed models. SAS Institute, Inc. Cary, North Carolina.

Merritt, R.W., and K.W. Cummins. 1996. An introduction to the aquatic insects of North America. $3^{\text {rd }}$ edition. Kendall/Hunt Publishing Co., Dubuque, Iowa.

Montgomery, D. C. 2004. Design and Analysis of Experiments, Sixth Edition. John Wiley \& Sons, Inc. New York, New York.

Paul, M. J., and J. L. Meyer. 2001. Streams in the urban landscape. Annual Review of Ecology and Systematics 32:333-365.

Peckarsky, B.L., P.R. Fraissinet, M.A. Penton, and D.J. Conklin, Jr. 1990. Freshwater Macroinvertebrates of Northeastern North America. Cornell University Press, Ithaca, New York.

Plafkin, J. L., M. T. Barbour, K. D. Porter, S. K. Gross, and R. M. Hughes. 1989. Rapid bioassessment protocols for use in streams and rivers: Benthic Macroinvertebrates and fish. EPA/440/4-89-001. Office of Water, US Environmental Protection Agency, Washington, DC.

Platts, W. S., R. J. Torquemada, M. L. McHenry, and C. K. Graham. 1989. Changes in salmon spawning and rearing habitat from increased delivery of fine sediment to the South Fork Salmon River, Idaho. Transactions of the American Fisheries Society 118:274-283.

Rabeni, C. F., and M. A. Smale. 1995. Effects of siltation on stream fish and the potential mitigating role of the buffering zone. Hydrobiologia 303:211-219.

Riley, S. P. D., G. T. Busteed, L. B. Kats, T. L. Vandergon, L. F. S. Lee, R. G. Dagit, J. L. Kerby, R. N/ Fisher, and R. M. Sauvajot. 2005. Effects of urbanization on the 
distribution and abundance of amphibians and invasive species in Southern California Streams. Conservation Biology 19:1894-1907.

Roth, N. E., M. T. Southerland, G. Mercurio, J. C. Chaillou, P. F. Kazyak, S. S. Stranko, A. P. Prochaska, D. G. Heimbuch, and J. C. Seibel. 1999. State of Streams: 1995-1997 Maryland Biological Stream Survey Results. Maryland Department of Natural Resources, Annapolis, Maryland.

SAS Institute Inc. 1999. SAS Procedure Guide, SAS OnlineDoc®, Version 8, Cary, North Carolina.

Sheridan, G. J., and P. J. Noske. 2007. A quantitative study of sediment delivery and stream pollution from different forest road types. Hydrological Processes 21: 387-398.

Smith, M.E., and J. L. Kaster. 1983. Effect of rural highway runoff on stream benthic macroinvertebrates. Environmental Pollution (Series A) 32:157-170.

Stepenuck, K. F., R. L. Crunkilton, and L. Wang. 2002. Impacts of urban land use on macroinvertebrate communities in Southeastern Wisconsin Streams. Journal of the American Water Resources Association 38:1041-1051.

Stevens, E., B. J. Barfield, S. L. Britton, and J. S. Hayes. 2004. Filter Fence Design Aid for Sediment Control at Construction Sites. EPA/600/R-04/185. United States Environmental Protection Agency, National Risk Management Laboratory, Office of Research and Development, Cincinnati, Ohio.

Stewart-Oaten, A., W. M. Murdoch, and K. R. Parker. 1986. Environmental impact assessment: “pesudoreplication" in time? Ecology 67:929-940.

Stewart-Oaten, A., and J. R. Bence. 2001. Temporal and spatial variation in environmental impact assessment. Ecological Monograph 71: 305-339. 
Sokal, R. R., and F.J. Rohlf. 1995. Biometry. W. H. Freeman and Company, New York.

Steel, R. G. D., J. H. Torrie, , and D. A. Dickey. 1997. Principles and Procedures of Statistics: A Biometrical Approach. The McGraw-Hill Companies, Inc., New York.

Sugden, B. D., and S. W. Woods. 2007. Sediment production from forest roads in Western Montana. Journal of the American Water Resources Association 43:193-206.

Underwood, A.J. 1994. On beyond BACI: sampling designs that might reliably detect environmental disturbances. Ecological Applications 4:3-15.

U. S. EPA (United States Environmental Protection Agency). 1996. Quality Criteria for Water 1986. EPA 440/5-86-001. Office of Water Regulations and Standards, Washington, D.C.

U.S. EPA (United States Environmental Protection Agency). 2000. A stream condition index for West Virginia wadeable streams, Region 3 Environmental Services Division. Prepared by Tetra Tech, Inc. July 21, 2000.

U.S. EPA (United States Environmental Protection Agency). 2005. National Management Measures to Control Nonpoint Source Pollution from Urban Areas. EPA-841-B-05-004 United States Environmental Protection Agency Office of Water, Washington, DC. U. S. EPA (United States Environmental Protection Agency). 2006. Wadeable Streams Assessment: A Collaborative Survey of the Nation's Streams. EPA 841-B-06-002 United States Environmental Protection Agency Office of Water Regulations and Standards, Washington, D.C.

Van Hassel, J. H., J. J. Ney, and D. L. Garling. 1980. Heavy metals in a stream ecosystem at sites near highways. Transactions of the American Fisheries Society 109:636-643. 
Wang, L. and P. Kanehl. 2003. Influences of watershed urbanization and instream habitat on macroinvertebrates in cold water streams. Journal of the American Water Resources Association 39:1181-1196.

Wiggins, G. B. 1996. Larvae of the North American caddisfly genera (Trichoptera). University of Toronto Press, Toronto, Canada.

Wigington, P. J., C. W. Randall jr., and T. J. Grizzard. 1983. Accumulation of selected trace metals in soils of urban runoff detention basins. Water Resources Bulletin 19:709-717.

Wellman, J. C., D. L. Combs, and S. B. Cook. 2000. Long-term impacts of bridge and culvert construction or replacement on fish communities and sediment characteristics of streams. Journal of Freshwater Ecology 15:317-328.

Williams, D. D., and H. B. N. Hynes. 1976. The recolonization mechanisms of stream benthos. Oikos 27:265-272.

Wolman, M. G. 1967. Cycle of Sedimentation and Erosion in Urban River Channels. Geografiska Annaler 49:385-395.

World Health Organization. 1996. Water Quality Assessments - A Guide to Use of Biota, Sediments and Water in Environmental Monitoring - Second Edition. D. Chapman (ed). University Press, Cambridge, United Kingdom. 
Table 1. Water quality variables associated with upstream and downstream sites in the Lost River watershed, West Virginia. Ranges of each variable are reported from the monitoring period of 1998 through 2007.

\begin{tabular}{|c|c|c|c|c|}
\hline $\begin{array}{c}\text { Water Quality } \\
\text { Parameter }\end{array}$ & $\begin{array}{l}\text { Range for } \\
\text { Freshwater } \\
\text { Organisms }\end{array}$ & Source & Upstream & Downstream \\
\hline $\mathrm{pH}$ & 6 to 9 & $\begin{array}{l}\text { Stumm and } \\
\text { Morgan } 1996\end{array}$ & 6.41 to 9.29 & 6.31 to 9.60 \\
\hline Acidity & not available & & 0.01 to $13.0 \mathrm{mg} / \mathrm{L}$ & 0.01 to $14.7 \mathrm{mg} / \mathrm{L}$ \\
\hline Alkalinity & 10 to $400 \mathrm{mg} / \mathrm{L}$ & $\begin{array}{l}\text { Jenkins et al. } \\
1995\end{array}$ & $\begin{array}{c}15.62 \text { to } 161.5 \\
\mathrm{mg} / \mathrm{L}\end{array}$ & 11.94 to $203.5 \mathrm{mg} / \mathrm{L}$ \\
\hline Conductivity & not available & & 36.2 to $263 \mu \mathrm{s}$ & 28.6 to $508 \mu \mathrm{s}$ \\
\hline Turbidity & not available & & 0 to $43 \mathrm{NTU}$ & 0 to $99 \mathrm{NTU}$ \\
\hline TSS & $<25 \mathrm{mg} / \mathrm{l}$ & WHO 1996 & 0.15 to $24.3 \mathrm{mg} / \mathrm{L}$ & 0.15 to $51.0 \mathrm{mg} / \mathrm{L}$ \\
\hline Chloride & $<11 \mathrm{mg} / \mathrm{L}$ & US EPA 1986 & 0.05 to $21.2 \mathrm{mg} / \mathrm{L}$ & 0.80 to $45.9 \mathrm{mg} / \mathrm{L}$ \\
\hline Sulfate & $<100 \mathrm{mg} / \mathrm{L}$ & WHO 1996 & 0 to $25.1 \mathrm{mg} / \mathrm{L}$ & 0 to $77.0 \mathrm{mg} / \mathrm{L}$ \\
\hline \multirow[t]{2}{*}{ Iron } & $<0.3 \mathrm{mg} / 1$ & WHO 1996 & 0 to $0.45 \mathrm{mg} / \mathrm{L}$ & 0 to $1.11 \mathrm{mg} / \mathrm{L}$ \\
\hline & $<1 \mathrm{mg} / \mathrm{L}$ & $\begin{array}{l}\text { Jenkins et al. } \\
1995\end{array}$ & & \\
\hline Phosphate & not available & & 0.0 to $0.52 \mathrm{mg} / \mathrm{L}$ & 0.0 to $0.51 \mathrm{mg} / \mathrm{L}$ \\
\hline Calcium & not available & & 1.50 to $73.0 \mathrm{mg} / \mathrm{L}$ & 2.36 to $92.4 \mathrm{mg} / \mathrm{L}$ \\
\hline Nitrate & $<40 \mathrm{mg} / 1$ & WHO1996 & $\begin{array}{c}0.002 \text { to } 6.28 \\
\mathrm{mg} / \mathrm{L}\end{array}$ & 0.00 to $10.11 \mathrm{mg} / \mathrm{L}$ \\
\hline Ammonia & $0.04-1.0 \mathrm{mg} / 1$ & WHO 1996 & 0 to $0.12 \mathrm{mg} / \mathrm{L}$ & 0 to $0.20 \mathrm{mg} / \mathrm{L}$ \\
\hline
\end{tabular}


Table 2. Results from ANCOVA of metrics associated with the benthic macroinvertebrate at sites located downstream of highway construction in the Lost River watershed, Hardy County, West Virginia.

\begin{tabular}{|c|c|c|c|c|c|c|c|c|c|c|c|c|}
\hline \multirow[b]{2}{*}{$\begin{array}{l}\text { Construction } \\
\text { Period }\end{array}$} & \multicolumn{2}{|c|}{$\begin{array}{c}\text { \% Top } 2 \\
\text { Dominant }\end{array}$} & \multicolumn{2}{|c|}{$\%$ Chironomidae } & \multicolumn{2}{|c|}{$\%$ EPT } & \multicolumn{2}{|c|}{$\underline{\mathrm{HBI}}$} & \multicolumn{2}{|c|}{$\underline{\text { EPT Taxa }}$} & \multicolumn{2}{|c|}{$\underline{\text { Total Taxa }}$} \\
\hline & t Value & $\operatorname{Pr}>|t|$ & t Value & $\operatorname{Pr}>|t|$ & t Value & $\operatorname{Pr}>|t|$ & t Value & $\operatorname{Pr}>|t|$ & t Value & $\operatorname{Pr}>|t|$ & t Value & $\operatorname{Pr}>|t|$ \\
\hline $\begin{array}{l}\text { Before vs. } \\
\text { During }\end{array}$ & 2.95 & 0.013 & -0.23 & 0.821 & 1.9 & 0.084 & -2.85 & 0.016 & 0.8 & 0.439 & 0.87 & 0.404 \\
\hline $\begin{array}{l}\text { During vs. } \\
\text { After }\end{array}$ & 1.24 & 0.240 & 2.95 & 0.013 & -1.15 & 0.275 & 1.12 & 0.286 & 3.42 & 0.006 & 1.96 & 0.076 \\
\hline $\begin{array}{c}\text { Before vs. } \\
\text { After }\end{array}$ & -2.21 & 0.049 & 2.63 & 0.024 & -3.01 & 0.012 & 4.01 & 0.002 & 1.83 & 0.095 & 0.65 & 0.528 \\
\hline
\end{tabular}


Figure 1. Location of study sites in the Lost River watershed, Hardy County, West Virginia, USA.

Figure 2. Time series of water quality variables associated with sites upstream and downstream of highway construction. Means with standard error bars are plotted by season $(\mathrm{F}=$ fall, $\mathrm{SP}=$ spring, and year); vertical bars indicate plus and minus one standard error. Highway construction occurred within the time period of Fall 2000 through Fall 2003 (bracketed by vertical bars).

Figure 3. Mean values of metric scores with standard error bars associated for sites upstream and downstream of highway construction during three construction time periods, before, during, and after construction. Mean values with different letters differ significantly $(\mathrm{p}<$ $0.05)$. 


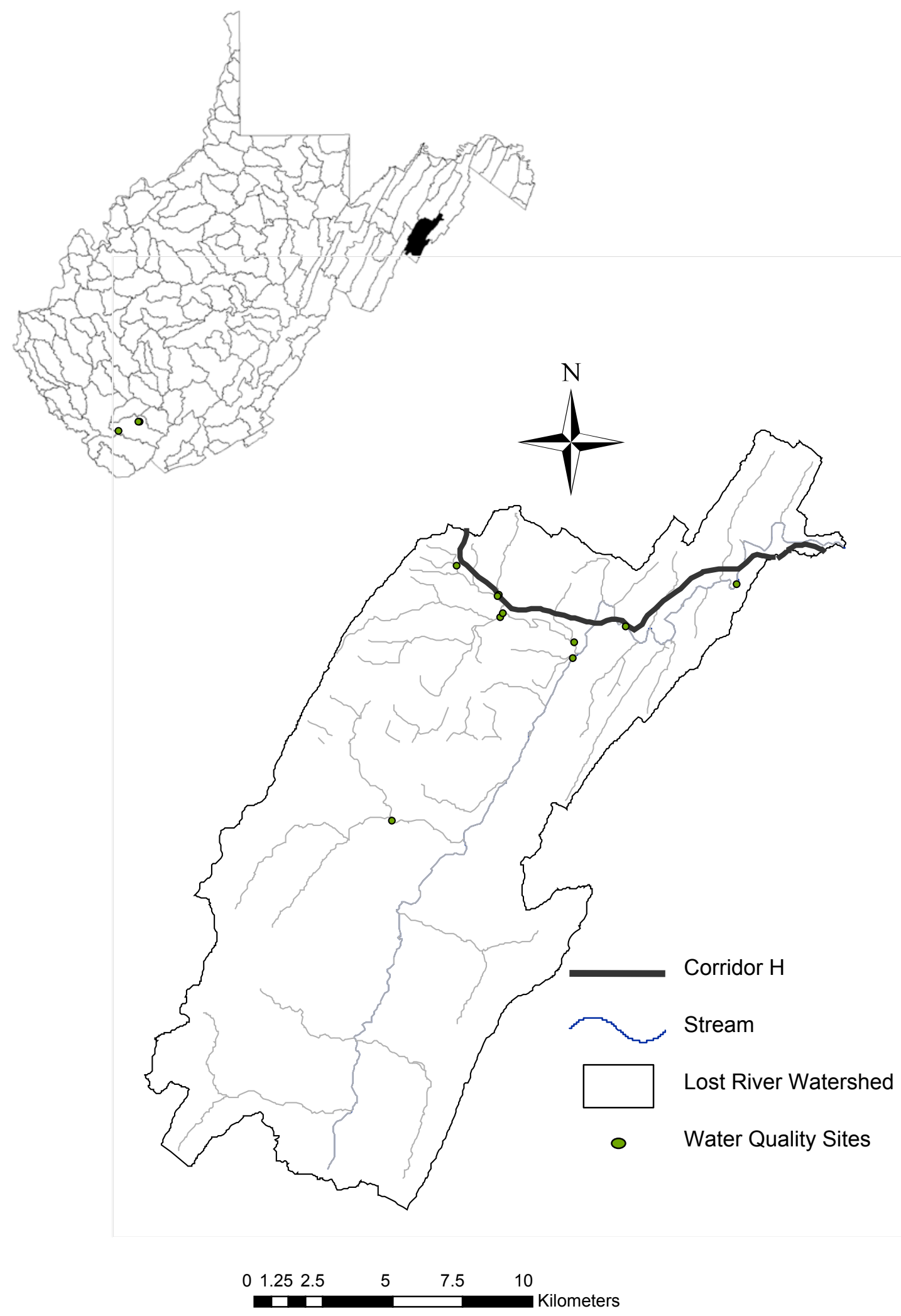


Figure 2
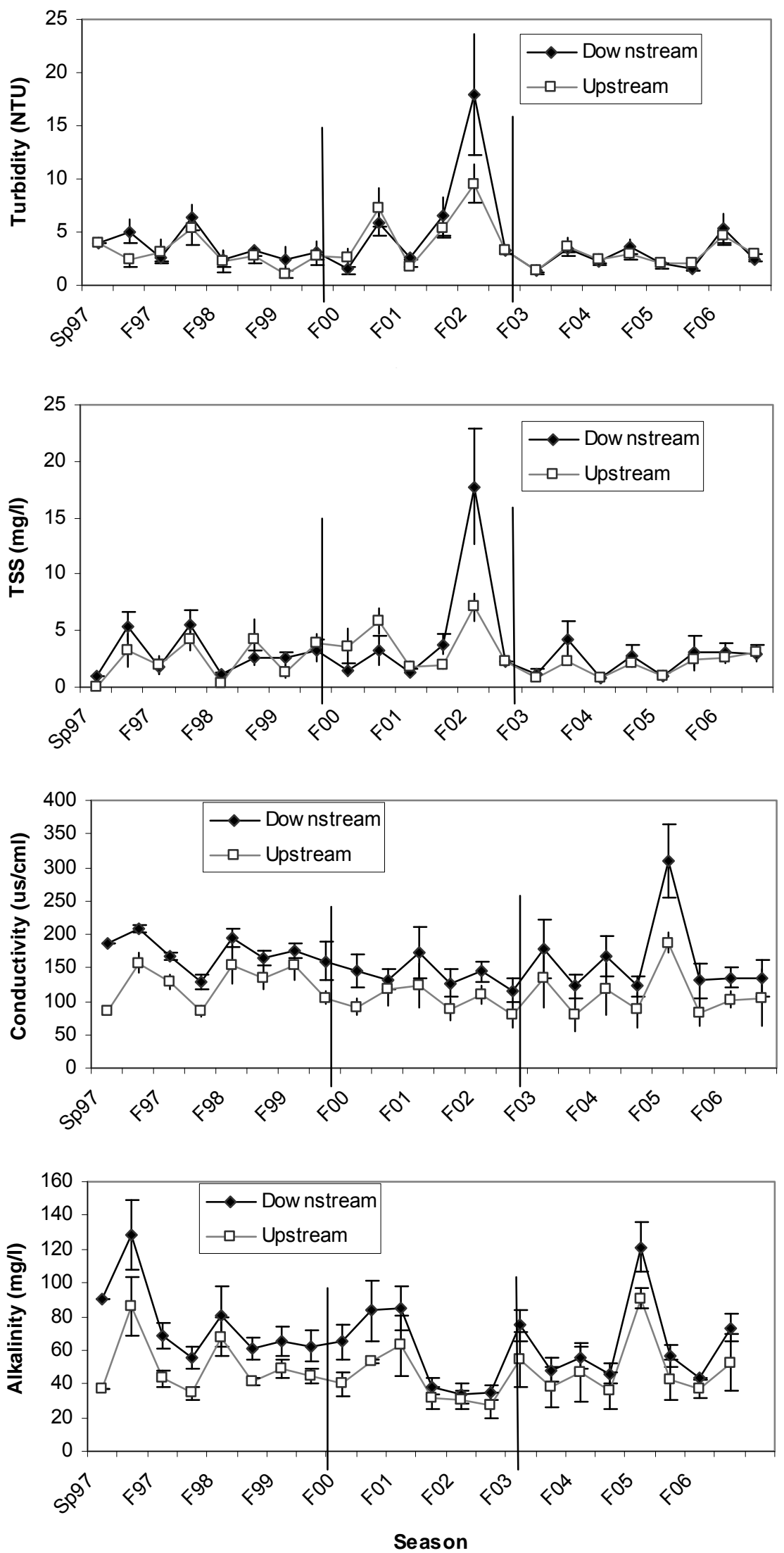

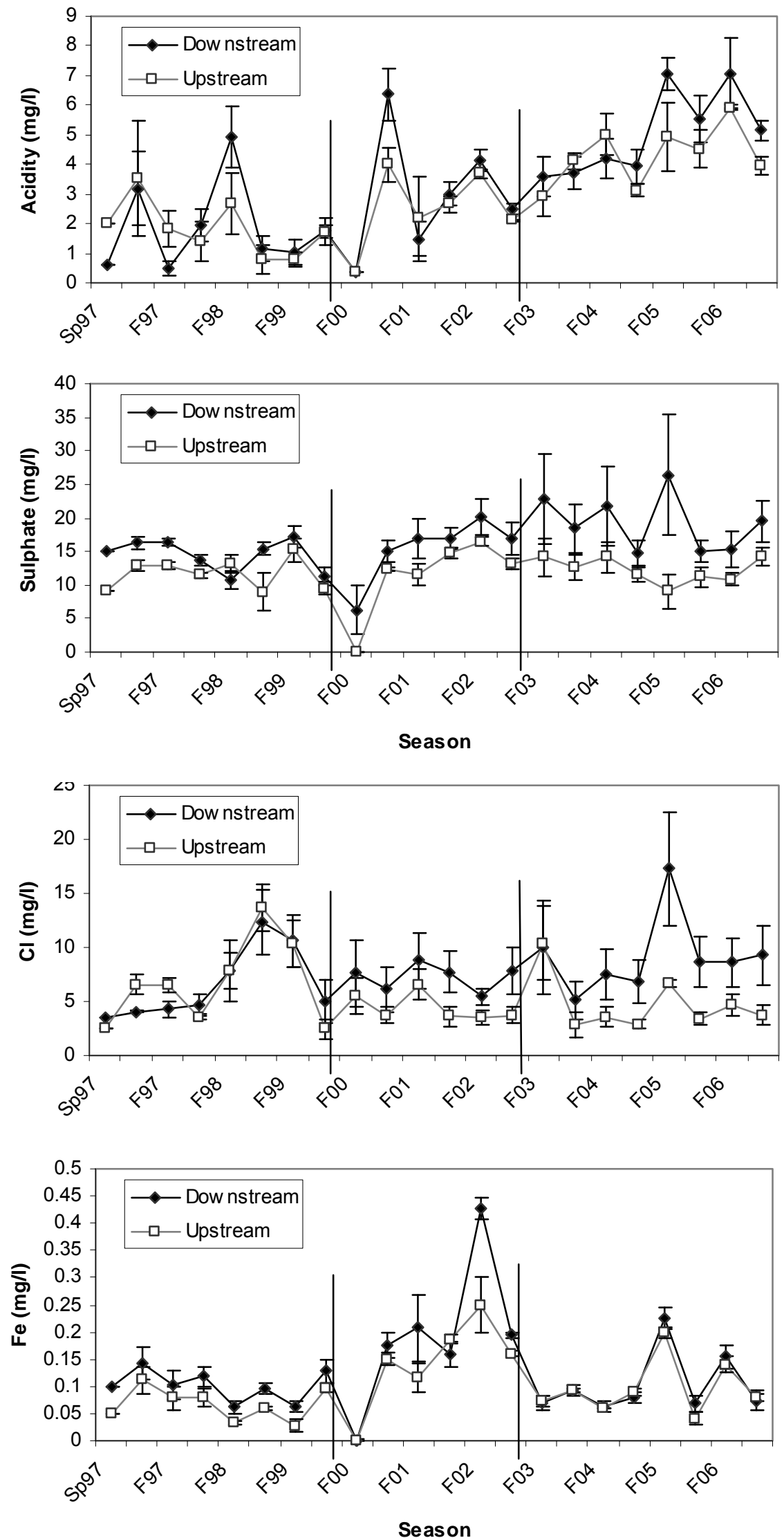

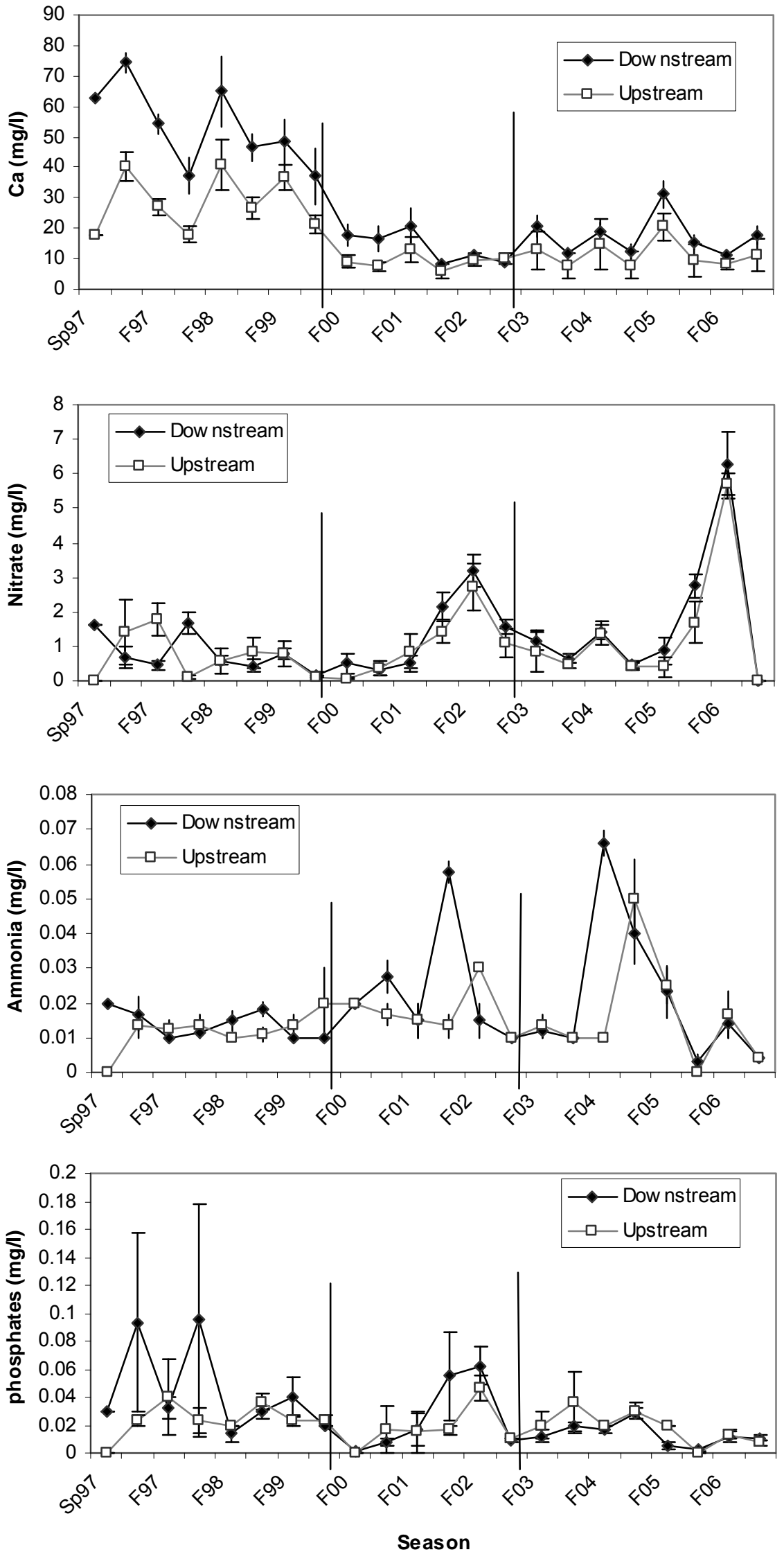
Figure 3.
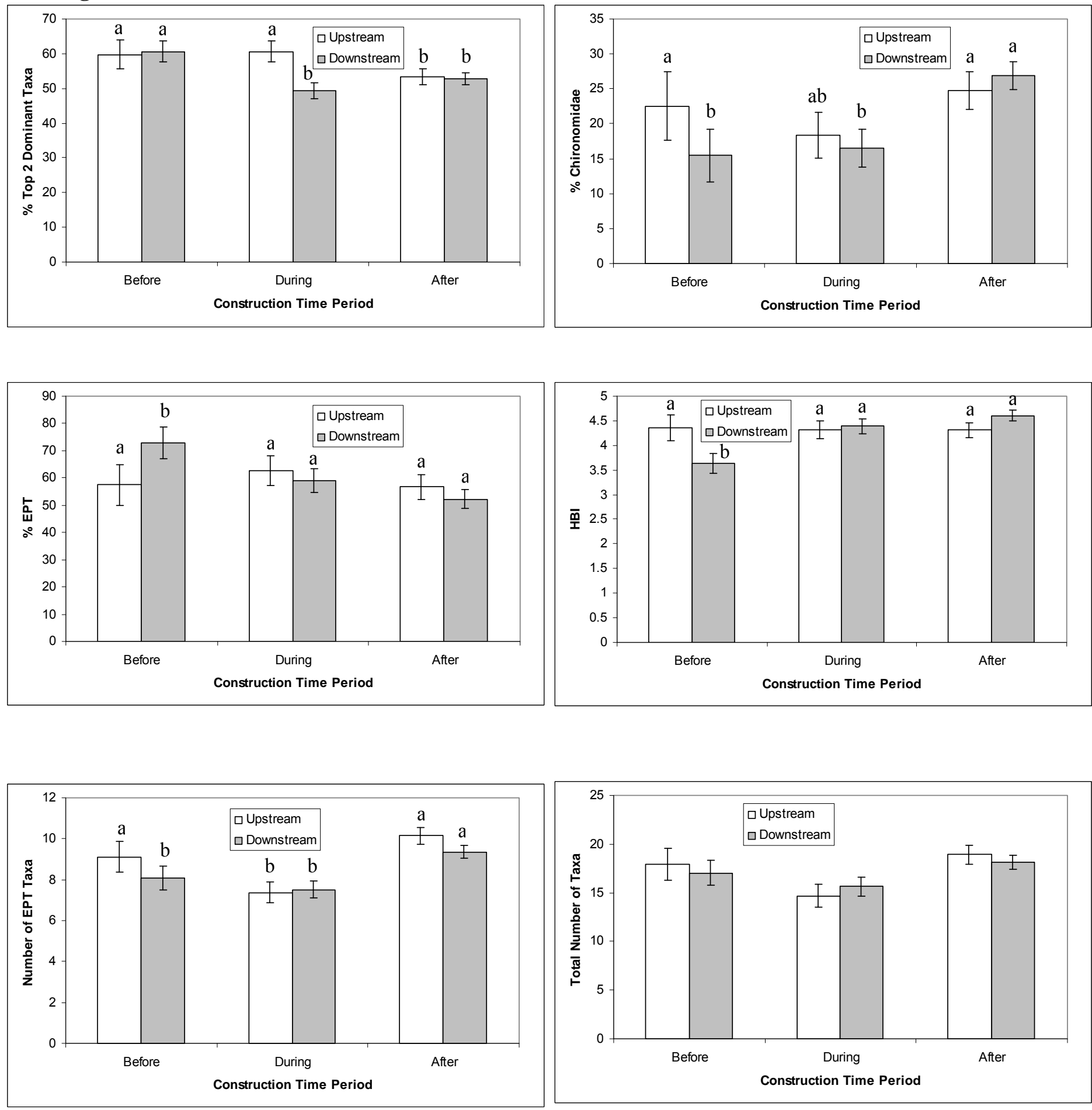


\section{Chapter 7: Management Implications}

Corridor $\mathrm{H}$ is a four-lane highway being constructed in the eastern panhandle of West Virginia. From 1997 through 2007 we had the opportunity to monitor the Lost River watershed before, during, and after highway construction in Hardy County, West Virginia. We assessed highway impacts by evaluating sedimentation, stream geomorphology changes, benthic macroinvertebrate communities, and water chemistry at sites located upstream and downstream of highway construction.

Monitoring of sedimentation using a new sediment trap design (Hedrick et al. 2007) indicated that sites downstream of construction collected a higher percentage of material $>4.7$ $\mathrm{mm}$ in diameter, and a greater amount of total sediment in grams (Hedrick et al. 2007). When sediment fencing on Sauerkraut Run, a tributary of the Lost River, failed during a period in August 2002, sedimentation increased, causing aggradation of the streambed and negatively effecting the benthic macroinvertebrate communities. Re-establishment of appropriate sediment fencing decreased the amount of sediment and the benthic macroinvertebrate community recovered quickly. This indicates that when appropriate Best Management Practices (BMPs) are applied and functioning properly they are useful in reducing the impacts of construction.

We surveyed longitudinal profiles and cross sections in a reference reach and altered reach of Sauerkraut Run from 2003 through 2007 to measure changes in the streambed. The altered reach included a section upstream of construction where a gravel berm was constructed to redirect flow, a straightened channel section where a temporary culvert was placed and removed, and downstream of the temporary culvert to State Route 55. Vegetation was removed from the banks in construction area, and downstream vegetation had been removed previously on the left bank when Sauerkraut Road was treated with asphalt in 1999. During the four-year period, three 
high flow events occurred. Although the reference section upstream of construction showed little change in morphology in response to these events, cross sectional profiles of the altered reach indicated that it went through changes including channel widening, aggradation, and then degradation of the stream bed. The upstream reference reach is connected to the floodplain and has a healthy riparian of mature trees and vegetation along both banks. This study shows the importance of flood plain and riparian. When the culvert was removed in September 2004, the streambed was regarded with gravel material, the elevation was increased by $0.3 \mathrm{~m}$, and a long riffle section was created. Over the next year, as the stream channel adjusted, elevation degraded and several small pools were created. The altered reach would benefit from natural channel design, including the addition of meanders and riffle/pool complexes, and improvement of the riparian zone by planting of trees along the channelized section that passes under the overpass. Riparian vegetation will help prevent the stream from widening and will protect the banks from future erosion. Bernard et al. (2007) provide a comprehensive guide on stream restoration and channel design that could be useful in developing a stream channel and riparian area that would be less likely to become unstable, erode, and cause further sedimentation.

The long term monitoring study of sites located upstream and downstream of construction reinforce the conclusions made in our sediment monitoring study, and increases in turbidity and total suspended solids were documented during construction. The increases were not consistent during the construction time period, but occurred as spikes, most likely related to runoff events due to rain. These results emphasize the need for sediment fencing, sediment ponds, and other BMP designs. During construction other water quality constituents, such as iron (related to increases in turbidity), and nitrates and phosphates, due to fertilization of areas being reseeded, also occurred. Benthic macroinvertebrate response to changes in water quality 
and habitat due to sedimentation included a shift to a more tolerant community at downstream sites. The percent of chironomidae (a family considered tolerant of degradation) and the Hilsenhoff Biotic Index (HBI) increased, while percent of Ephemeroptera, Plectoptera, and Trichoptera (EPT - orders sensitive to environmental degradation) decreased.

Our 10-year study addressed short-term impacts of highway construction, and found that impacts were relatively minimal. However, this study only addressed a period of three years before construction, three years during construction and four years post construction. Inferences can not be made concerning the long-term impacts of the highway, highway traffic, road runoff, and other factors associated with highway use. Continual monitoring of the watershed is necessary to determine if the occurrence and use of the highway, as well as associated urbanization will have a continual impact on stream habitat, water quality, and biotic integrity.

\section{References}

Bernard, J., J. F. Fripp, and K. R. Robinson. 2007. Part 654 Stream Restoration Design National Engineering Handbook (210-VH-NEH). USDA Natural Resources Conservation Service, Washington, D. C.

Hedrick, L.B., S.A. Welsh, and J. T. Anderson. 2007. Effects of highway construction on sediment and benthic macroinvertebrates in two tributaries of the Lost River, West Virginia. Journal of Freshwater Ecology 22:561-569. 


\section{Curriculum Vitae}

\section{LARA B. HEDRICK}

205 EVERgreEn LANE, FORT ASHBY, WV 26719

PHONE 304-298-2107 • EMAIL: larahedrick@frontiernet.net

\section{Education}

2002 to Present

West Virginia University

Morgantown, WV

Doctor of Philosophy, Wildlife and Fisheries Resources (4.0)

Dissertation: Evaluation of the impacts of highway construction on sediment and benthic macroinvertebrates in Appalachian streams

Advisor: Dr. Stuart A. Welsh

1996 to 1999

University of Maryland, Eastern Shore

Princess Anne, MD

Master of Science, Ecology (4.0)

Thesis: Population estimates and movements of nutria Myocastor coypus in a managed Maryland marsh

Advisor: Dr. F. Joseph Margraf

1992 to 1996

West Virginia University

Morgantown, WV

Bachelor of Science, Wildlife and Fisheries Resources (major 4.0, overall 3.8)

\section{Relevant Course Work}

\begin{tabular}{llll}
\hline West Virginia & WMAN 550 & Fish Ecology & A \\
University & WMAN 512 & Advanced Population Ecology & A \\
& WMAN 693O & Advanced Ichthyology & A \\
& WMAN 693Q & Fish Physiology & A \\
& WMAN 633 & Quantitative Ecology & A \\
& WMAN 693T & Conservation Biology & A \\
& WMAN 445 & Fisheries Management & A \\
& RESM 591 & Spatial Analysis for Resource Mngmt & A \\
STATS 512 & Statistical Methods 2 & A \\
University of & BIOL 661 & Community Ecology & A \\
Maryland & ENVS 684 & Natural Resource Management & A \\
& MEES 698P & Environmental Toxicology & A \\
& AGSC 605 & Statistics in Agriculture Research & A \\
& MEES609L & Aquaculture and Fisheries Science & A \\
& MEES698Q & Aquatic Ecology & A \\
& MEES 698C & Dynamics of Exploited Marine Pop & A \\
& MEES 608G & Seagrass and Marsh Ecology & A
\end{tabular}




\section{Professional Experience}

Spring 2005

1/2002 to Present

$2 / 2000$ to $12 / 2002$

$10 / 1999$ to $2 / 2000$
Instructor, Ichthyology (BIO 341)

Department of Biology, West Virginia University

Supervisor: Dr. Stuart A. Welsh

- Create lectures, laboratory assignments, quizzes and tests

- Proctor exams and lab practicals

- Enrollment: 72 upper level undergraduates

Graduate Research Assistant

Morgantown, WV West Virginia Cooperative Fish and Wildlife Research Unit, West Virginia University

Supervisor: Dr. Stuart A. Welsh, Assistant Unit Leader (304) 293-2941 ext 2419

- Design a study to determine the impacts of highway construction on the benthic macroinvertebrate and fish populations in streams impacted by Corridor $\mathrm{H}$

- Develop a sampling design for evaluating sedimentation in streams impacted by highway construction

- Provide monthly reports to cooperators on progress made and data analyzed

Aquatic Biologist

Beaver, WV

Research, Environmental, and Industrial Consultants (REIC)

Supervisor: Ed Kirk, Director, Biological Division

- Design proposals for fisheries, benthic macroinvertebrate, and water quality studies according to client needs, and federal and state regulations

- Coordinate meetings between State and Federal agencies and clients, coal and hydroelectric power industries, to create management and mitigation strategies for fisheries and aquatic resources impacted by industry

- Initiate communication and cooperation with the general public and private landowners for the establishment of biological monitoring locations on private property

- Develop sampling logistics, data analysis techniques, and reporting protocols; Analyze data and provide reports to clients and other interested parties (legal professionals and agencies)

- Conduct biological investigations of benthic macroinvertebrates, fisheries communities, aquatic habitat, riparian evaluations, substrate characterizations, stream geomorphology, and fisheries cover

- Identification of all experimental fishes to species

- Collaboration with WVDNR, WVDEP, and US EPA to provide and maintain a database that can beutilized to assess aquatic resources throughout the state

Fisheries Research Assistant Moscow, ID

Idaho Cooperative Fish and Wildlife Research Unit, University of Idaho Supervisor: Dr. Ted Bjornn (deceased)

- Database management for a salmonid radio-tracking project on the Snake and Columbia Rivers

- Data entry and analysis utilizing Lotus 1-2-3 and Lotus Approach, ArcView, SAS

- Research and prepare reports on previous radio tracking data, specifically on migration patterns of steelhead trout, factors influencing migration, and management strategies to increase successful adult passage at the dams on the Snake River 
- Develop techniques for the capture, transport, holding and larval rearing of Atlantic menhaden

- Collect, enter, and analyze data, and prepare technical reports on various fisheries research projects

- Collect fish in the coastal bays and estuaries of Maryland, Delaware, Virginia and New Jersey, using a variety of techniques including electro fishing, gillnets, seines, pound nets, fyke nets, and larval fish tows

- Construct fish holding facilities for flow through and recirculating systems

- Hold and maintain adult and juvenile fish in captivity, both onshore and in-situ cages, in experimental tanks, and aquaculture facilities

- Perform necropsy techniques on fish samples for analysis by cooperating scientists

- Maintain boats, trailers and sampling equipment

- Observe catches of commercial and recreational fishermen

- Use a variety of sampling equipment including ISCO samplers, hydrolabs, and YSI units, to collect water quality data and samples

- Population census of nutria using capture - recapture techniques, and home range study on nutria utilizing radio telemetry

- Use of LOCATE II, CALHOME, and ArcView ${ }^{\mathrm{TM}}$ 3.2; to determine home range and movement patterns, and habitat types used within home range areas.

- Part of a committee creating an eradication program for nutria for the State of Maryland, involved in creating an informational nutria handout for public education

\section{Research Assistant} Tudor Farms

Supervisor: Dr. Edward Soutiere
Cambridge, MD

(410) 228-8290

- Data collection for a GIS project involving delineating apparent vegetation types using infra-red aerial photographs and verifying by direct observation

- Vegetation sampling, wetland plant identification and wetland delineation

- Digitizing vegetation polygons using ArcView

\section{Peer Reviewed Publications}

2008 Hedrick, L. B., S. A. Welsh, J. T. Anderson, and J. D. Hedrick. In press. Evaluation of a new sediment sampling device. Proc. Annu. Conf. Southeast. Assoc. Fish and Wildl. Agencies :-

2007 Hedrick, L. B., S. A. Welsh, and J. T. Anderson. 2007. Effects of highway construction on sediment and benthic macroinvertebrates in two tributaries of the Lost River, West Virginia. Journal of Freshwater Ecology 22:561-569. 
2005 Hedrick, L. B., S.A. Welsh, and J.D. Hedrick. 2005. A new sampler design for measuring sedimentation in streams. North American Journal of Fisheries Management 25:238-244.

2005 Hedrick, J. D., L. B. Hedrick, and F. J. Margraf. 2005. A sampler for capturing larval and juvenile Atlantic menhaden. North American Journal of Fisheries Management 25:245-250.

2005 Cincotta, D.A., S.A. Welsh, D.P. Wegmen, L.B. Hedrick, and T.E. Oldham. In press. Fishes of the Blackwater River drainage with a discussion of their status and origin in Canaan Valley and its Environs: a Landscape Heritage Celebration, Canaan Valley Institute, Canaan Valley, WV.

\section{TECHNICAL REPORTS}

2002 Hedrick, J. D. and L. B. Ras 2002. Conceptual mitigation plan for Barnet Run and Ming Run, Coastal Coal - West Virginia, LLC. Report to Coastal Coal - West Virginia, LLC. 8 pp.

2002 Hedrick, J. D. and L. B. Ras. 2002. Determination of aquatic impacts associated with the Rollem Fork No.2 Surface Mine SMA No. S-5025-00. Report to Pen Coal Corporation. 44 pp.

2002 Hedrick, J. D. and L. B. Ras. 2002. Determination of aquatic impacts associated with the Copley Trace Branch No. 2 Surface Mine SMA No. S-5026-98. Report to Pen Coal Corporation. 35 pp.

2001 Hedrick, J. D., and L. B. Ras. 2001. Determination of aquatic impacts associated with Callisto Surface Mine, SMA No. S-5009-00. Reported to Sammons Law Office, Charleston, WV and Callisto Coal Company, Beckley, WV. 30 pp.

2001 Kirk, E. J., J. D. Hedrick, and L. B. Ras. 2001. Benthic macroinvertebrate, habitat, water chemistry, and fisheries studies of stations on Trough Fork and Big Laurel Creek. Report to Pen Coal Corporation, Inc., 72 pp.

2001 Kirk, E. J., J. D. Hedrick, and L.B. Ras. 2001. Benthic macroinvertebrate, habitat, water chemistry, and fisheries studies of stations associated with proposed valley fills on Rollem Fork. Report to Pen Coal Corporation. 83 pp

2001 Kirk, E. J., J. D. Hedrick, and L. B. Ras. 2001. Environmental assessment for water quality impacts and permits, wetland impacts, and water body modification and wildlife impacts from the Clarksburg / Grafton Road Project, (State Project U217-50-18.03, Federal Project STP0050(170)E). Report to L. A. Gates Company, 2303 South Fayette Street, Beckley, West Virginia 25801. 7 p.

2001 Kirk, E. J., J. D. Hedrick, and L. B. Ras. 2001. Benthic macroinvertebrate, habitat, water chemistry, and fisheries study of streams associated with 4 proposed valley fills at the Republic No. 1 Surface Mine. Report to C. C. Coal Company, Cabin Creek, West Virginia. 136 p.

1999 Hedrick, J. D., L. B. Ras, and F. J. Margraf. 1999. Distribution, progression, and species specific incidence of fish skin abnormalities in the Pocomoke River system. 1998 Annual Report. Maryland Department of Natural Resources, Cooperative Oxford Laboratory. Oxford, Maryland.

1999 Ras, L. B., J. D. Hedrick, and F. J. Margraf. 1999. Distribution, progression, and species specific incidence of fish skin abnormalities in Maryland. $19992^{\text {nd }}$ Quarterly Report. Maryland Department of Natural Resources, Cooperative Oxford Laboratory. Oxford, Maryland.

1998 Hedrick, J. D., L. B. Ras, and F. J. Margraf. 1998. Distribution, progression, and species specific 
incidence of fish skin abnormalities in the Pocomoke River system. $19983^{\text {rd }}$ Quarterly Report. Maryland Department of Natural Resources, Cooperative Oxford Laboratory. Oxford, Maryland.

\section{Presentations}

2008 Hedrick, L., S. Welsh, and J. Anderson. Effects of highway construction on sediment and benthic macroinvertebrates in two tributaries of the Lost River, WV. Presented at the Southern Division of the American Fisheries Society 2008 Spring Meeting, Wheeling, WV, 1 March 2008.

2007 Hedrick, L., S. Welsh, J. Anderson and J. Hedrick. Evaluation of a new sediment sampling device. Presented at the Southeastern Association of Fish and Wildlife Agencies meeting, Charleston, WV, October 2007.

2004 Hedrick, L. and S.A. Welsh. New methods for estimation and analysis of stream sedimentation. Presented at the American Society of Ichthyologists and Herpetologists meeting, Norman, OK, 26 May- 1 June 2004.

2004 Hedrick, L., S. Welsh, J. Anderson, and R. Fortney. 2004. Monitoring anthropogenic sediment inputs in Appalachian streams. Poster presented at the Northeastern Association of Fish and Wildlife Agencies Conference, Ocean City, Maryland, 27 April 2004.

2004 Hedrick, L., S. Welsh, J. Anderson, and R. Fortney. 2004. Assessing influences of highway construction on Appalachian streams. Presented at the Northeastern Association of Fish and Wildlife Agencies Conference, Ocean City, Maryland, 27 April 2004.

2004 Hedrick, L., S.A. Welsh, J. Anderson, and R. Fortney. 2004. Assessing influences of highway construction on Appalachian streams. Presented at the annual Graduate Student Conference of the Davis College of Agriculture, Forestry, and Consumer Sciences, West Virginia University, 8 April 2004.

2004 Hedrick, L. and S.A.Welsh. Assessing sedimentation in Appalachian headwater streams. MidAtlantic Water Pollution Biology Workshop, Cacapon State Park, West Virginia. 25 March 2004.

2004 Hedrick, L. B. and S. A. Welsh. Analysis of sediment data from Sauerkraut Run using information theoretic methods. Presented at the West Virginia Chapter of the American Fisheries Society Annual Meeting, Clarksburg, WV, 6 February 2004

2003 Bounds, D. L. and L. B. Hedrick. Movements and population estimates of nutria in Maryland wetlands. Invited Presentation to Symposium SSO8: Nutria: Biology, Impacts, and Management. Presented at the Society of Wetland Scientists 24th Annual Meeting, New Orleans, LA, 12 June 2003. (Invited)

2003 Hedrick, L. B., and S. A. Welsh. A sampler design for monitoring impacts of road construction. Presented at the West Virginia Chapter of the American Fisheries Society Annual Meeting, Morgantown, WV, 24 April 2003.

2003 Hedrick, J. D., and L. B. Hedrick. A sampler design for capturing larval and juvenile fishes for propagation. Presented at the West Virginia Chapter of the American Fisheries Society Annual Meeting, Morgantown, WV, 24 April 2003. 
2003 Hedrick, L. B., and S. A. Welsh. A sampler design for monitoring impacts of road construction. Invited Presentation to Symposium: Southern Dirt: Sedimentation in Southeastern Waters. Presented at the Southern Division American Fisheries Society Spring Meeting, Wilmington, NC, 15 February 2003. (Invited)

2002 Hedrick, J. D., and L. B. Hedrick. Cumulative Impacts of Mountain Top Mining on Receiving Streams and Watersheds. Presented at the American Fisheries Society 132nd Annual Meeting, Baltimore, MD 22 August 2002.

2002 Hedrick, L.B., and J. D. Hedrick. Effects of Mountain Top Mining on Habitat and Water Chemistry in Headwater Streams. Presented at the American Fisheries Society $132^{\text {nd }}$ Annual Meeting, Baltimore, MD, 22 August 2002.

2002 Hedrick, L.B., and J. D. Hedrick. Aquatic impacts resulting from valley fill construction. Presented at the West Virginia Chapter of the American Fisheries Society, Morgantown WV, 26 April 2002

2002 Ras, L.B., and J. D. Hedrick. Determination of aquatic impacts resulting from valley fill construction. Presented at the West Virginia Surface Mine Drainage Task Force Symposium, Morgantown WV, 16 April 2002

2002 Ras, L. B. Ecology and management of nutria on the Eastern Shore of Maryland. Presented at the West Virginia Chapter of The Wildlife Society Meeting, Stonewall Jackson State Park, WV, 7 March 2002

2001 Hedrick, J. D., E. J. Kirk, and L. B. Ras. Biological Monitoring of Trough Fork Between 1995 and 2000. Presented at the Aquatic Issues Stakeholders Meeting, Wheeling Jesuit University, WV, May 2001.

1999 Ras, L. B., D. L. Bounds, F. J. Margraf, and E. Soutiere. Population estimates of nutria and hunting trends at Tudor Farms, Dorchester County, Maryland. Presented at the North American Aquatic Furbearers Conference, Mississippi State University, MS, May 1999

1998 Ras, L. B., D. L. Bounds, F. J. Margraf, and E. Soutiere. Population and home range estimates of nutria at Tudor Farms. Presented at the Exotic Species Symposium, USGS Patuxent Wildlife Research Center, Laurel, MD, August 1998.

\section{ACCOMPLishmenTs}

2004 Patent received on a Sediment Sampler for Aquatic Environs

U.S. Patent Number 6,823,749 awarded November 30, 2004

\section{Professional Organizations and Awards}

1993 Inducted, Xi Sigma Pi - Forestry Honor Society

1995 Inducted, Phi Kappa Phi - National Honor Society

1998 Member, American Fisheries Society

2001 Certified Associate Fisheries Professional, American Fisheries Society

2004 Member, American Society of Ichthyologists and Herpetologists

2004 Northeast Division of AFS Travel Award 


\section{WORKSHOPS ATTENDED}

2006 Advanced Macroinvertebrate Ecology and Identification. Instructed by Dr. J. Reese Voshell, Jr. and Stephen Hiner. National Conservation Training Center, Shepherdstown, WV. March 6-10, 2006.

2003 Fish Identification Course. Instructed by Dr. Stuart Welsh and Dan Cincotta. National Conservation Training Center, Shepherdstown, WV. November 17-21, 2003.

2003 Sediment Transport Monitoring Workshop. Instructed by Lee Chavez, Consulting Hydrologist. Canaan Valley Institute, Davis, WV. August 18-22, 2003.

2001 Applied Fluvial Geomorphology Course. Instructed by Dave Rosgen, Principle Hydrologist, Wildland Hydrology Consultants. San Jose, CA. October 2001.

\section{OTHER RELEVANT EXPERIENCE}

2007 Review of manuscripts Wetlands, Journal of the Society for Wetland Scientists

2006 Review of manuscripts for North American Journal of Fisheries Management

2004 Review of manuscripts for Southeastern Association of Fish and Wildlife Agencies Annual Conference

2003 Introduction to Power Point Workshop. Co-taught with Pat Mazik, West Virginia University. August 2003.

2003 Introduction to Power Point Workshop. Assisted students. West Virginia University. January 2003.

2003 Review of Manuscipts for Southeastern Association of Fish and Wildlife Agencies Annual Conference

\section{KNOWLEDGE, SKILLS, AND ABILITIES}

- Proficient in office software: Microsoft ${ }^{\mathrm{TM}}$ products: Access, Excel, Word, PowerPoint, Outlook, WordPerfect,

- Proficient with SASTM 8.1, NTSYSpc, program MARK, Statistix

- Proficient in GIS Software: ESRI ArcGISTM 8.3, ArcView ${ }^{\text {TM }}$ 3.2; Extensions Spatial Analyst,

- Geostatistical Analyst

- First Aid and CPR Certified by American Red Cross 
Dr. Stuart A. Welsh, Assistant Unit Leader - Fisheries

(304) 293-2941 ext 2419

West Virginia Cooperative Fish and Wildlife Research Unit

West Virginia University

POB 6125, Morgantown, WV 26506

swelsh@wvu.edu

Dr. Patricia Mazik, Unit Leader

West Virginia Cooperative Fish and Wildlife Research Unit

(304) 293-2941 ext 2431

West Virginia University

POB 6125, Morgantown, WV 26506

pmazik@wvu.edu

Dr. James T. Anderson, Ph.D.

West Virginia University

(304) 293-2941 ext 2445

Division of Forestry and Natural Resources

PO Box 6125

Morgantown, WV 26506-6125

jander25@wvu.edu

Dr. F. Joseph Margraf, MS graduate advisor

(907) 474-7661

University of Alaska Fairbanks

209 Irving I Building

PO Box 757020

Fairbanks, AK 99775-7020

ffjfm1@uaf.edu 